\title{
Green Synthesis of Gold Nanoparticles Using Plant Extracts as Beneficial Prospect for Cancer Theranostics
}

\author{
Kaushik Kumar Bharadwaj ${ }^{1,+} \mathbb{D}$, Bijuli Rabha ${ }^{1,+}$, Siddhartha Pati ${ }^{2,3,+} \mathbb{D}$, Tanmay Sarkar ${ }^{4,5}$, \\ Bhabesh Kumar Choudhury ${ }^{6}{ }^{(D}$, Arpita Barman ${ }^{1}$, Dorothy Bhattacharjya ${ }^{1}$, Ankit Srivastava ${ }^{7}$, \\ Debabrat Baishya ${ }^{1, *}$, Hisham Atan Edinur ${ }^{8} \mathbb{D}^{\circ}$, Zulhisyam Abdul Kari ${ }^{9}{ }^{(D)}$ and Noor Haslina Mohd Noor ${ }^{10, *}$
}

Citation: Bharadwaj, K.K.; Rabha, B. Pati, S.; Sarkar, T.; Choudhury, B.K.; Barman, A.; Bhattacharjya, D.; Srivastava, A.; Baishya, D.; Edinur, H.A.; et al. Green Synthesis of Gold Nanoparticles Using Plant Extracts as Beneficial Prospect for Cancer Theranostics. Molecules 2021, 26, 6389 https://doi.org/10.3390/ molecules26216389

Academic Editors: Li Li and Nilesh Nirmal

Received: 1 October 2021

Accepted: 19 October 2021

Published: 22 October 202

Publisher's Note: MDPI stays neutral with regard to jurisdictional claims in published maps and institutional affiliations.

Copyright: (c) 2021 by the authors. Licensee MDPI, Basel, Switzerland. This article is an open access article distributed under the terms and conditions of the Creative Commons Attribution (CC BY) license (https:/ / creativecommons.org/licenses/by/ $4.0 /)$.
1 Department of Bioengineering \& Technology, GUIST, Gauhati University, Guwahati 781014, Assam, India; kkbhrdwj01@gmail.com (K.K.B.); bijulipep@gmail.com (B.R.); arpitabarman532@gmail.com (A.B.); dorothybhatta@gmail.com (D.B.)

2 SIAN Institute, Association for Biodiversity Conservation and Research (ABC), Balasore 756001, Odisha, India; patisiddhartha@gmail.com

3 Department of Biotechnology, Academy of Management and Information Technology, Khordha 752057, Odisha, India

4 Malda Polytechnic, West Bengal State Council of Technical Education, Government of West Benga, Malda 732102, West Bengal, India; tanmays468@gmail.com

5 Department of Food Technology and Biochemical Engineering, Jadavpur University, Kolkata 700038, West Bengal, India

6 Department of Chemistry, Gauhati University, Guwahati 781014, Assam, India; bkcsat@gmail.com

7 Department of Biotechnology, Motilal Nehru National Institute of Technology, Allahabad (Prayagraj) 211004, Uttar Pradesh, India; anku054@gmail.com

8 School of Health Sciences, Health Campus, Universiti Sains Malaysia, Kubang Kerian 16150, Kelantan, Malaysia; edinur@usm.my

9 Faculty of Agro Based Industry, Universiti Malaysia Kelantan, Jeli 17600, Kelantan, Malaysia; zulhisyam.a@umk.edu.my

10 Haematology Department, School of Medical Sciences, Universiti Sains Malaysia Health Campus, Kubang Kerian 16150, Kelantan, Malaysia

* Correspondence: drdbaishya@gmail.com (D.B.); drhaslina@usm.my (N.H.M.N.)

+ Each authors contributed equally to this work.

Abstract: Gold nanoparticles (AuNPs) have been widely explored and are well-known for their medical applications. Chemical and physical synthesis methods are a way to make AuNPs. In any case, the hunt for other more ecologically friendly and cost-effective large-scale technologies, such as environmentally friendly biological processes known as green synthesis, has been gaining interest by worldwide researchers. The international focus on green nanotechnology research has resulted in various nanomaterials being used in environmentally and physiologically acceptable applications. Several advantages over conventional physical and chemical synthesis (simple, onestep approach to synthesize, cost-effectiveness, energy efficiency, and biocompatibility) have drawn scientists' attention to exploring the green synthesis of AuNPs by exploiting plants' secondary metabolites. Biogenic approaches, mainly the plant-based synthesis of metal nanoparticles, have been chosen as the ideal strategy due to their environmental and in vivo safety, as well as their ease of synthesis. In this review, we reviewed the use of green synthesized AuNPs in the treatment of cancer by utilizing phytochemicals found in plant extracts. This article reviews plant-based methods for producing AuNPs, characterization methods of synthesized AuNPs, and discusses their physiochemical properties. This study also discusses recent breakthroughs and achievements in using green synthesized AuNPs in cancer treatment and different mechanisms of action, such as reactive oxygen species (ROS), mediated mitochondrial dysfunction and caspase activation, leading to apoptosis, etc., for their anticancer and cytotoxic effects. Understanding the mechanisms underlying AuNPs therapeutic efficacy will aid in developing personalized medicines and treatments for cancer as a potential cancer therapeutic strategy.

Keywords: gold nanoparticles; AuNPs; green synthesis; anticancer; plants; therapy 


\section{Introduction}

The term "nanotechnology" refers to the design, development, and implementation of components that are 10-1000 nanometers in size. Nanotechnology is currently a multidisciplinary field that encompasses engineering, biology, chemistry, and physics [1,2]. The nanoparticle's size, optoelectronic and chemical properties, along with their unique structural morphology, has attracted researchers toward various biomedical, and food-related implications [3-6]. Carbon nanotubes, polymeric nanoparticles, metallic nanoparticles, microbially synthesized nanoparticles, liposomes, and magnetic nanoparticles are among the most studied nanostructures for biomedical applications in cancer therapy and diagnosis [7-16]. Cancer, a disease under which the body's healthy cells mutate from their normal state and divide uncontrollably, is recognized as a major medical challenge in the 21st century. One of the serious worries of scientists and physicians is the escalating incidence of cancer and the continuously growing mortality rate. Remarkably efficient cancer therapy and diagnosis are now regarded as one of the century's toughest challenging obstacles in health and medicine. Despite significant advancements in drug development and delivery, their numerous side effects and poor specificity and sensitivity, which most often harm healthy tissues and organs, have been substantial impediments to their use [17]. On the other hand, the prevalence of tumour cells resistant to conventional cancer treatments such as chemotherapy, radiotherapy, and surgery, as well as causing numerous adverse responses and disappointing treatment outcomes, shows the critical need for the enhancement and development of antitumor therapeutic research that has the potential to target tumours and kill cancer cells effectively, having very few side effects [18]. Cancer nanomedicines, also known as magic bullets, have become widely utilized in cancer treatment because of their remarkable efficacy and safety. The use of nanoparticles in cancer treatment has substantially increased drug delivery to the target compared to conventional drug administration methods. It significantly enhances the safety and effectiveness of the most commonly utilised anticancer drugs. Effective targeting, delayed-release, prolonged half-life, and reduced toxicity are the significant benefits of nanomedicine and delivery systems [19]. Since the FDA approved the first nano formulated anticancer drug, Doxil Caelyx (Janssen) (Liposomal Doxorubicin (PEGylated)) in 1995, for the treatment of Ovarian and HIV-associated Kaposi's sarcoma, the numbers of nanomedicines used to treat cancer has increased dramatically [20]. The US FDA and EMA currently approved various nanotechnology-based anticancer drugs, such as Myocet (Teva UK) (EMA 2000) (liposomal doxorubicin (non-PEGylated)) (treatment of metastatic breast cancer), DaunoXome (Galen) (FDA 1996, EMA 2018) (liposomal daunorubicin (non-PEGylated)) (HIV-associated Kaposi's sarcoma), ONPATTRO Patisiran ALN-TTR02 (Alnylam Pharmaceuticals) (FDA 2018) (lipid nanoparticle RNAi) (Transthyretin (TTR)-mediated amyloidosis), and VYXEOS CPX-351 (Jazz Pharmaceuticals) (FDA 2017, EMA 2018) (liposomal formulation of cytarabine: daunorubicin) (acute myeloid leukaemia) [21]. Metallic nanoparticles are small metal particles that range in size from 1 to 100 nanometers $(\mathrm{nm})$. Silver $(\mathrm{Ag})$, aluminium ( $\mathrm{Al})$, iron $(\mathrm{Fe})$, gold $(\mathrm{Au})$, silica $(\mathrm{Si})$, copper $(\mathrm{Cu})$, zinc $(\mathrm{Zn})$, manganese $(\mathrm{Mn})$, cerium $(\mathrm{Ce})$, titanium (Ti), platinum $(\mathrm{Pt})$, or thallium (TI) have all been utilized in the synthesis of nanoparticles (NPs) [22]. Various metallic nanoparticles have been designed for the treatment and diagnosis of cancer. The most prominent anti-cancer nanoparticles are gold $(\mathrm{Au})$, silver $(\mathrm{Ag})$, zinc $(\mathrm{Zn})$, and platinum $(\mathrm{Pt})$ due to their size and shape-dependent tuneable optoelectronic properties [23]. Alloy NPs such as CoNi nanoparticles were successfully developed for cancer theranostics [24]. The unique size of the metal NPs impacts the toxicity in the human cancer cells and is size-dependent. The cytotoxicity of different-sized silver nanoparticles (AgNPs), when analysed, demonstrated that AgNPs with the size of $10 \mathrm{~nm}$ were more cytotoxic than those $20-80 \mathrm{~nm}$ size due to the high surface area, resulting in more efficient cell-particle interaction and increased intracellular silver bioavailability than larger NPs [25]. Tumour tissues are more permeable to NPs than normal tissues because of their leaky vasculature and inadequate lymphatic drainage. This facilitated the synthesized NPs being more permeable to tumour tissues, enabling NPs to easily penetrate cancerous cells 
and kill them. Furthermore, the presence of hydrophilic molecules on the surface of metal nanoparticles increases their solubility and half-life by protecting them from macrophagemediated absorption, allowing them to stay in the systemic circulation longer [26,27]. Gold nanoparticles (AuNPs) are becoming promising cancer therapeutic and diagnostic metal NPs that attract researchers due to their unique physiochemical properties such as stability, biocompatibility, high thermal activity, optical, electrical, high surface area to volume ratio surface chemistry, and multifunctionalization, etc. By fine tuning the components and concentrations, AuNPs can be easily manufactured into various forms and sizes [28-30]. AuNPs have also shown significant advancement in treating inflammatory diseases and bacterial infections [31,32].

Green synthesis is regarded as a promising method for NPs synthesis because of the utilization of cost-effective and non-hazardous raw materials [33]. This method of NPs synthesis is sustainable with great therapeutic efficacy, reduced toxicity, targeted binding, and site-specific delivery. Additionally, this does not affect human health and the environment [34,35]. As shown in Figure 1, NPs are typically synthesized using two approaches: top-down and bottom-up. The most means of NPs synthesis are found in the bottom-up approach, in which NPs are made from simpler molecules [36]. Due to economic cost, the plant-based green synthesis methodology is one of the best choices for the large-scale generation of AuNPs with well-defined size and morphology [37]. Plants are preferred candidates for NPs synthesis over microorganisms, such as fungi and bacteria, since plants do not require the complex process of maintaining microbial cultures [19].

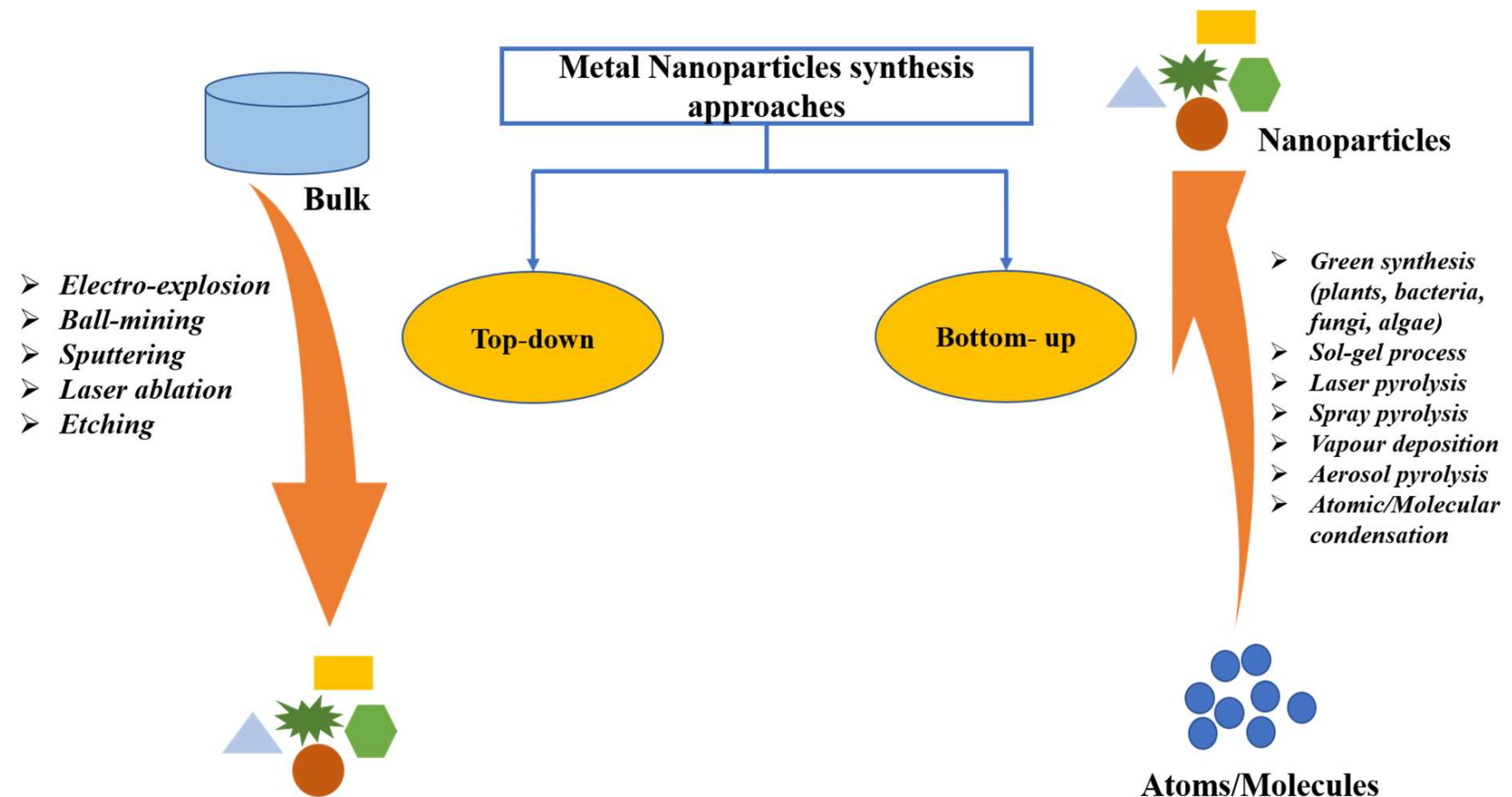

Nanoparticles

Figure 1. Different approaches of metal nanoparticles synthesis.

This article aims to provide an overview of green synthesized AuNPs, including their characterization methods and applications in cancer therapy and diagnosis. Anticancer properties of AuNPs are detailed, along with their putative mechanisms of action on various cell lines, based on the literature. Important therapeutic and future challenges of AuNPs in terms of anticancer were reviewed before the article was concluded. 


\section{Properties of Gold Nanoparticles}

To synthesize stable nanoparticles (NPs), gold ( $\mathrm{Au}$ ) is regarded as suitable metal. Most of the physical properties of inorganic nanoparticles are found to be dependent on the size and shape of the NPs. The gold nanoparticles (AuNPs) have wide applications in different fields due to their specific optical and physical properties. AuNPs possess significant properties, such as (a) small size (1-100 nm), (b) physical and chemical properties based on size, shape, and composition, (c) excellent robustness, (d) qualitative and quantitative target binding ability, etc. [38].

\subsection{Shape and Size}

There are various methods for the synthesis of AuNPs having different shapes and sizes. The size and shape of AuNPs are the two primary parameters that control the chemical, physical and electrocatalytic properties of gold nanoparticles. Metal nanoparticles in the size range of 1-10 $\mathrm{nm}$ have size-dependent properties compared to bulk materials [39]. There are very few methods for the production of AuNPs with uniform sizes. Michael Faraday introduced the two-phase system to prepare AuNPs by reducing gold salt by phosphorous in carbon disulphide for the first time. Researchers have developed a popular method for synthesising smaller AuNPs. They reduced gold salt by sodium borohydride in the presence of the capping agent dodecanethiol [40]. They confirmed the size of the NPs in the range 1-3 nm using HRTEM (High-Resolution Transmission Electron Microscopy). It is possible to control the size of NPs by varying the concentration of thiols. G. Frens agreed with Turkevich's data that reduction of gold chloride salt using sodium citrate solution is an efficient method to prepare monodispersed gold nanoparticles of different diameters. By changing the ratio of reactants, independent nucleation and growth of metal nanoparticles with different diameters can be achieved [41,42]. The size of AuNPs are tuneable through the alteration of gold precursor and reducing the power of reducing agents. It is observed that strong reducing agents, such as $\mathrm{NaBH}_{4}$ offer the synthesis of small size AuNPs and weaker reducing agents, such as citrate, resulted in comparatively larger NPs. Researchers have investigated the effect of chloride ion concentration on the size of AuNPs via citrate reduction. They find that size of gold NPs are caused by the aggregation of gold NPs induced by chloride ions [43]. In a typical synthesis, chloroauric acid $\left(\mathrm{HAuCl}_{4}\right)$ is reduced by $5 \%$ sodium citrate solution at room temperature. The chloride ion concentration is varied using different concentrations of $\mathrm{NaCl}$ solutions. They performed the same experiment using $\mathrm{NaBH}_{4}$ as a reductant, and the interesting results are placed in Table 1. The table includes the data for the effect of different concentrations of $\mathrm{NaCl}$ on the size of AuNPs in the presence of different reactants such as sodium citrate and sodium borohydride, respectively. With an increase in $\mathrm{NaCl}$ concentration from 1 to $20 \mathrm{mM}$, the UV-visible absorption maxima (max) are also shifted towards higher wavelengths that indicate an increased size of AuNPs.

Table 1. The effect of $\mathrm{Cl}^{-}$ion concentration and reductant on AuNPs size.

\begin{tabular}{|c|c|c|c|}
\hline & $\begin{array}{c}\text { Concentration of } \mathrm{NaCl} \\
(\mathrm{mM})\end{array}$ & $\begin{array}{c}\text { UV-Visible Absorption Maxima } \\
{\left[\lambda_{\max }(\mathrm{nm})\right]}\end{array}$ & $\begin{array}{l}\text { Size Ranges from TEM } \\
\text { (nm) }\end{array}$ \\
\hline $\begin{array}{c}\mathrm{HAuCl}_{4}(0.25 \mathrm{mM})+5 \% \\
\text { Sodium citrate } \\
\text { (Both the reactants are in 5:1 ratio) }\end{array}$ & $\begin{array}{c}1 \\
5 \\
10 \\
15 \\
20\end{array}$ & $\begin{array}{l}517 \\
520 \\
525 \\
528 \\
531\end{array}$ & $\begin{array}{l}19 \mathrm{~nm}( \pm 7) \\
25 \mathrm{~nm}( \pm 11) \\
38 \mathrm{~nm}( \pm 21) \\
40 \mathrm{~nm}( \pm 31) \\
47 \mathrm{~nm}( \pm 36)\end{array}$ \\
\hline \multirow{2}{*}{$\begin{array}{c}\mathrm{HAuCl}_{4}(0.25 \mathrm{mM})+\text { Sodium } \\
\text { borohydride }\left(\mathrm{NaBH}_{4}\right)\end{array}$} & 0 & 490 & 3 \\
\hline & 20 & 520 & 12 \\
\hline
\end{tabular}

Solvents used in the synthesis of NPs play an important role as either interaction between nanoparticle surface and solvent molecule or solvent and ligand molecules direct its final size and morphology [44,45]. Scholars have challenged the two-phase synthesis of NPs by Brust and co-workers and developed a single-phase synthesis of monodispersed 
gold nanoparticles using borane complexes as a reductant in organic solvents. In a typical process, $\mathrm{AuPPh}_{3} \mathrm{Cl}(0.25 \mathrm{mmol})$ and dodecanethiol $(0.125 \mathrm{mmol})$ is mixed with benzene, and $2.5 \mathrm{mmol}$ solution of the tert-butylamine-borane complex is added as reductant that forms $6.2 \mathrm{~nm}$ size gold nanoparticles [46]. In a modified Stucky's method, Song and coworkers have prepared mono dispersed AuNPs from the reaction of $\mathrm{AuPPh}_{3} \mathrm{Cl}$ with an amine borane complex tert-butylamine borane (TBAB) having thiol ligand. In the absence of thiol, the AuNPs are found to have polydispersity, while in the presence of thiol, the synthesized NPs are monodispersed, having a size of $5.0 \mathrm{~nm} \pm 0.4 \mathrm{~nm}$ [47]. To synthesize large size AuNPs, the seeded growth method is preferred. In this method, small size gold nanoparticles have been synthesized that act initially as seeds for the growth of larger gold nanoparticles. Then, separation of nucleation and growth of the NPs, we may increase the size of AuNPs up to $300 \mathrm{~nm}[39,48]$. Stanglmair and co-workers have reported synthesizing monodispersed AuNPs with $20 \mathrm{~nm}$ average diameter in size via the seeded growth method. They synthesized gold nanoparticles of $9 \mathrm{~nm}$ size, in toluene as solvent and oleylamine as reductant cum stabilizing agent, were further used as a seed to produce AuNPs of $20 \mathrm{~nm}$ average size. Researchers have reported the synthesis of spherical shape AuNPs from $\mathrm{H}\left[\mathrm{AuCl}_{4}\right] \cdot 3 \mathrm{H}_{2} \mathrm{O}$ as a precursor, ascorbic acid as reductant and sodium citrate as a stabilizer. In the first step, they were able to synthesize NPs with $30 \mathrm{~nm}$ size, which then acts as a seed for the production of AuNPs, having $69 \mathrm{~nm}$ and $118 \mathrm{~nm}$ sizes and even further growth [49]. The report shows that AuNPs with different sizes and shapes, such as long nanorods, short nanorods, cubes and spheres can be prepared via reversible flocculate formation surfactant micelle-induced depletion interaction. To obtain different shapes of NPs, the tuning of surfactant concentration and extraction of flocculates from the sediment are important steps [50]. Jianhui Zhang, with his co-workers, has investigated the shape-selective synthesis of AuNPs with controlled size and different shapes, such as hexagons, belts, rods, triangles, octahedrons and dumbbells. In the process, water molecules are attached with poly(vinylpyrrolidone) (PVP) and n-pentanol to form a two-phase system of water/PVP/npentanol (WPN). PVP can act as a reductant and stabilizer where the presence of water can modify the reducing ability of PVP. However, they utilized PVP as a capping agent rather than a reductant. They have observed the region-selective distribution of water and PVP in the WPN system, which offers kinetically controlled growth of novel AuNPs nanostructures [51]. Researchers have studied the effect of temperature on the size of AuNPs by synthesizing gold nanoparticles varying temperature using tetraoctylammonium bromide (TOAB) as a stabilizer. The room temperature synthesis confirms AuNPs with an average size of $5.2 \mathrm{~nm}$ having a spherical shape. When the annealing of the AuNPs synthesis was performed at $100{ }^{\circ} \mathrm{C}$ for $30 \mathrm{~min}$, a drastic change in the shapes of the gold nanoparticles was observed. The sizes of nanoparticles change from $5.2 \mathrm{~nm}$ to $6 \mathrm{~nm}$, bearing shapes such as hexagons, pentagons, and squares under HRTEM observation, whose corresponding three-dimensional shapes are cuboctahedron, icosahedron, and a cube, respectively. On annealing, at $200{ }^{\circ} \mathrm{C}$, the morphology, as well as size of AuNPs, changed drastically. The HRTEM shows the average size of the NPs to be $15 \mathrm{~nm}$ with different shapes, such as hexagon, triangle and pentagons. Similarly, nanoparticles and nanocubes are obtained when annealing is performed at $300{ }^{\circ} \mathrm{C}$ [52]. An interesting process, called the dewetting process, has attracted the researcher in the synthesis of nanoporous AuNPs. In this method, Au/Ag bilayer alloy film is initially produced, where AuNPs are much smaller in comparison to silver nanoparticles (AgNPs). Then, AgNPs are removed by treating the $\mathrm{Au} / \mathrm{Ag}$ bilayer in $65 \mathrm{wt} \% \mathrm{HNO}_{3}$ solution at $21^{\circ} \mathrm{C}$, called dealloying. After dealloying, $\mathrm{Au}(5 \mathrm{~nm}) / \mathrm{Ag}(20 \mathrm{~nm})$ bilayer AuNPs with $274 \mathrm{~nm}$ are found, while $\mathrm{Au}(10 \mathrm{~nm}) / \mathrm{Ag}$ $(20 \mathrm{~nm})$ bilayer-formed AuNPs have a diameter of $307 \mathrm{~nm}$ [53]. Researchers have reported the synthesis of cap-shaped AuNPs with $110 \mathrm{~nm}$ size by evaporating gold adsorbed on polystyrene [54]. The atom-transfer radical polymerisation (ATRP) is a technique used by scholars to prepare monodispersed nanoparticles that might be useful for synthesizing NPs of other precursors [55]. Researchers have prepared gold nanoclusters in the size range 7-20 nm having positive and negative charges in presence of polyamidoamine dendrimers 
(PAMAM) or sodium citrate [56]. Luca and co-workers have synthesized gold nanostar (AuNS) from $\mathrm{HAuCl}_{4}$ as a precursor using hydroxylamine as a reductant above $\mathrm{pH} 11$ maintained by $\mathrm{HaOH}$ solution. AuNS are formed in the $\mathrm{pH}$ range 12-12.5 where below $\mathrm{pH} 11$, no reduction occurs to Au (III) species. Thus, $\mathrm{pH}$ plays an important role in the size and morphology determination of AuNPs [57]. The graphical abstract presented in Figure 2 tries to include varieties of available shapes for AuNPs.

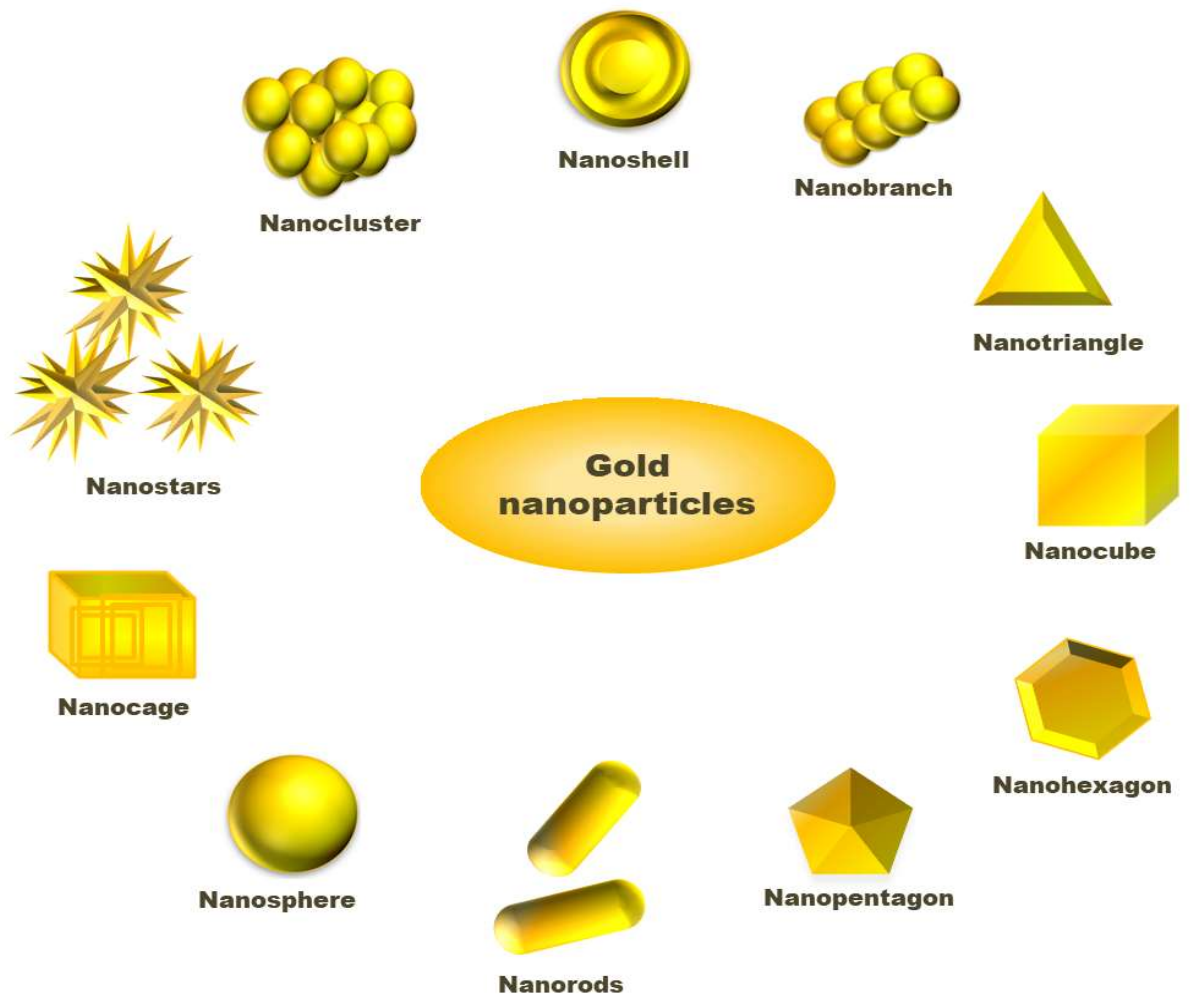

Figure 2. Different shapes available for gold nanoparticles.

\subsection{Optical Properties}

Nanoparticles possess excellent optical properties that are different from individual molecules and bulk metals. The optical properties of AuNPs related to surface plasmon resonance (SPR) are one of the reasons behind the vast success of AuNPs in nanoscience and technology [58]. As NPs are exposed to light, the oscillating electromagnetic field of light automatically induces collective coherent oscillation in the free electrons present in the conduction band of NPs. This eventually results in the charge separation that forms a dipole oscillation in the electric field of light. The amplitude of this oscillation reaches the zenith of maximum at a particular frequency known as surface plasmon resonance (SPR). The extent of SPR can be measured using a UV-visible spectrophotometer as the SPR absorbance for nanomaterials is much stronger than other metals. As per Mie theory, the SPR band intensity and wavelength depend upon factors, such as metal type, size, shape and structure of NPs, composition, and dielectric constant of the medium [59]. Researchers have used the photoacoustic technique (PA) to study the optical absorption properties of AuNPs with different shapes and sizes synthesized by them. They synthesized gold nanorods and nanospheres via seed-mediated growth techniques. For gold nanorods, the PA spectra are found to split into two modes, namely transverse and longitudinal. It is interesting to note that gold Nanospheres having size $\sim 20 \mathrm{~nm}$ in diameter have a characteristic strong PA absorption band centred at $\sim 522 \mathrm{~nm}$ while for nanorods, there was observed a two-band centred at $\sim 522 \mathrm{~nm}$ and $\sim 698 \mathrm{~nm}$ for transverse and longitudinal SPR. The gold nanoparticles of size $<2 \mathrm{~nm}$ in diameter do not show such absorption [60]. Researchers have reported a green synthetic method for AuNPs using starch as a reductant 
as well as capping agent. The report revealed second-order nonlinear optical (NLO) properties studied using continuous wave $(\mathrm{CW})$ He-Ne laser beam technique at wavelength $632.8 \mathrm{~nm}$. The non-linear refractive indices of AuNPs are obtained from a z-scan in the order of $10^{-7} \mathrm{~cm}^{2} / \mathrm{W}$ [61]. Researchers have reviewed various aspects of size-dependent SPR of AuNPs. The investigation shows that branched nanoparticles, also known by different other names, such as multi-pod, lumpy, star-shaped, sea urchin-like, etc. are not highly monodispersed as compared to other shapes. The longitudinal SPR (LSPR) of such branched nanostructure is well understood with the help of the plasmon hybridisation model (PH). This method calculates the LPSR of complex structures, assuming it to be the result of LPSR of simpler structures [62]. Optical transmission spectroscopy can be employed to study surface plasmon excitation for two identical interacting spherical AuNPs. Researchers have studied SPR for three pairs of AuNPs with sizes $450 \mathrm{~nm}, 300 \mathrm{~nm}$ and $150 \mathrm{~nm}$ in interaction. It is found that, with a decrease in the inter-particle distance, red shifts in SPR are observed, while blue shift is found for orthogonal polarisation [63]. AuNPs can enhance the Raman signal from $10^{6}$ to $10^{15}$ when exposed p monochromatic light. This phenomenon is called the surface-enhanced Raman scattering (SERS) technique that can be applied to distinguish tumour cells, mark tumour cells, or monitor tumour metabolism. AuNPs contain radioactive atoms that help in achieving desired radioactivity for treatment. Due to the high molar coefficient of AuNPs, they can be employed in the nanomolar level colourimetric analysis, as there is the advantage of the colour change of the AuNP-induced plasmon from red to blue, purple or grey after aggregation. The LPSR of AuNPs can act as a fluorescence quencher and fluorescence enhancer based on the distance between the fluorescence probe and AuNPs. The fluorescence resonance energy transfer (FRET) is considered a primary reason for fluorescence quenching by AuNPs. Aside from this, AuNPs can absorb photons to convert the light energy of a photon to kinetic energy. When light falls on AuNPs, the moving electrons are scattered by photons. A part of kinetic energy transformed to vibrational energy that was eventually expressed in the form of heat in the lattice. This is known as a photothermal effect. On photoexcitation, AuNPs can absorb energy and go to an excited state and then transfer energy to neighbouring molecules to act as photosensitizers similar to other organic photosensitizers or molecular oxygen [64].

\subsection{Electrical Properties}

The semiconductor industries believe that complementary metal-oxide semiconductors (CMOS) will reach their functional limits within 10-15 years. Then, nanomaterials or molecular assemblies on the nanometer level will occupy the space. Promising concepts developed in recent years include single-electron devices that retain their scalability up to molecular level. Individual charge carriers can be handled by exploiting Coulombic effects in metallic single-electron devices with tunnel junctions with micrometer size. Such a field is termed single electronics (SE). The AuNPs have attracted the research's attention in the approach to bridge the gap between CMOS and true atomic scale in the future [65]. In the case of nanoelectronics, monodispersed nanoparticles have a potential lot. Metal nanoparticles having a diameter $<2 \mathrm{~nm}$ are required for such devices to achieve the Coulomb blockade effect at room temperature [66]. Researchers have synthesized AuNPs through a green synthetic procedure using Solanum nigrum, Ricinus communis and Morus nigra, etc., extract as reducing agents. They performed experiments to evaluate the effect of adding AuNPs in the DC electrical conductivity and found that, with the increased addition of AuNPs, the DC electrical gradually increases [67]. Researchers have studied the size dependency of electronic properties of AuNPs nanoclusters up to 14 atoms through density functional theory and agree that the energetic and electronic properties of AuNPs nanoclusters depend on the size structures NPs [68]. Scholars have investigated the solvent-switchable electronic properties of gold nanoparticle/hydrogel composite. They have prepared a crosslinked polyacrylamide gels on Au-wire electrodes through the electro-polymerisation of acrylamide along with $\mathrm{ZnCl}_{2}$ and $N, N^{\prime}$-methylenebisacryamide. 
The "breathing" mechanism is adopted to introduce AuNPs into the polymer. It is found that the polymer used to get swollen when placed in water and get shrunken in acetone. The X-ray photoelectron spectroscopy (XPS), atomic absorption spectroscopy (AAS), quartz crystal microgravimetry (QCM), and Faradic impedance spectroscopy are used to know the inclusion of AuNPs in the polymer that shows a decrease in the swelling of the polymer with an increase in the AuNPs load. As the Au-polymer swells, it exhibits a resistance of $40 \mathrm{~K} \Omega$; while shrunken in acetone, it bears a resistance of $0.4 \mathrm{~K} \Omega$. Thus, it shows solvent switchable electrical properties [69]. Structural dielectric capacitors (SDCs) on doping with AuNPs shows enhanced electrical conductivity. They can improve both electrical as well as mechanical properties of carbon fibre reinforced polymer (CFRP)-based electrodes used in SDCs through AuNPs doping via epoxy matrix phase. AuNPs in the size range $2-5 \mathrm{~nm}$ in diameter are doped in different weight percentages in the range $0.025-1.0 \%$. In this experiment, graphene oxide (GO) film is a dielectric layer that separates two CFRP electrodes in SDCs. It is found that the electrical conductivity of AuNPs doped CFRP electrodes is 15-250\% higher than bare CFRP electrodes based on AuNPs percentage [70]. Similarly, scholars have reported the enhancement of electrical conductivity of carbon nanotube networks used as conductive fillers in a nanocomposite through AuNPs doping [71]. Silicon has semiconductor properties, and availability is considered a feasible option in the devices where biological responses are recorded as electrical signals. However, processing silicon materials as porous ones reduces the level of conductivity due to oxidation. This problem is resolved by embedding AuNPs into silicon-based materials through sputtering techniques. The gold NPs doped-silicon fibre composite shows more excellent conductivities at higher AuNPs concentrations with silicon nanofibers of smaller sizes [72].

\section{Green Synthesis of Gold Nanoparticles (AuNPs) from Plants}

Different physical and chemical synthesis protocols have been well known for the biosynthesis of AuNPs. However, most of those protocols were not well accepted due to toxic chemicals and elevated temperature in the synthesis process. They may be harmful to human beings and the environment $[73,74]$. The most common biosynthetic method is the extracellular nanoparticle production method [28]. The green synthesis of gold nanoparticles has been reported using plant tissues, bacteria, fungi, actinomycetes, etc. (Figure 3) [75]. However, the green synthesis of AuNPs from the plant is an eco-friendly approach. In the biosynthesis of AuNPs from the plant, different plant parts (leaf, bark, stem, root, etc.) are used as sources chopped into small pieces and boiled in distilled water to obtain the extract. By filtration and centrifugation, the extract can be purified. For metal salt solution $\mathrm{HAuCl}_{4}, \mathrm{AgNO}_{3}$ generally is mixed with plant extract at room temperature $[33,75]$. Plant extracts contain various metabolites or organic compounds (alkaloids, flavonoids, proteins, polysaccharides, cellulose, and phenolic compounds) and secondary metabolites, which are utilized for nanoparticle synthesis [76]. These can involve the bio reduction of metallic ions to NPs and act as stabilizing agents [77]. Plant extracts contain proteins that have functionalized amino groups $\left(-\mathrm{NH}_{2}\right)$ that can actively participate in the reduction reaction of AuNPs [68]. The functional groups (such as $-\mathrm{C}-\mathrm{O}-\mathrm{C}-,-\mathrm{C}-$ $\mathrm{O}-,-\mathrm{C}=\mathrm{C}-$, and $-\mathrm{C}=\mathrm{O}-$ ) present in phytochemicals, such as flavones, alkaloids, phenols, and anthracenes involve the generation of AuNPs. In this phenomenon, no external stabilising/capping agents are used because different phytochemicals act as reducing and stabilising/capping agents for the extracellular biosynthesis of AuNP, replacing the toxicity of chemicals such as sodium borohydride $\left(\mathrm{NaBH}_{4}\right)$ [78]. The bio reduction mechanism involves reducing metal ions from their mono or divalent oxidation state to a zero-valent state. After that, the nucleation of the reduced metal atoms takes place [79]. Ultimately, the metallic salt solution containing extract is reduced into $\mathrm{Au}^{3+}$ to $\mathrm{Au}^{0}$, and the synthesis of AuNP proceeds within minutes to hours using a one-pot, single-step and eco-friendly method [80]. Due to the presence of a variety of phytochemicals in plant extract, no particular mechanism for this synthesis process is reported. The variation in composition and concentration of reducing agents in plant extracts is responsible for different sizes, 
shapes, and morphological nanoparticle synthesis [81]. Researchers have reported that the size and morphology of nanoparticles can be expected to be different by changing the synthesis parameters, including $\mathrm{pH}$, metal salt, $\mathrm{pH}$, temperature and reaction time [82].
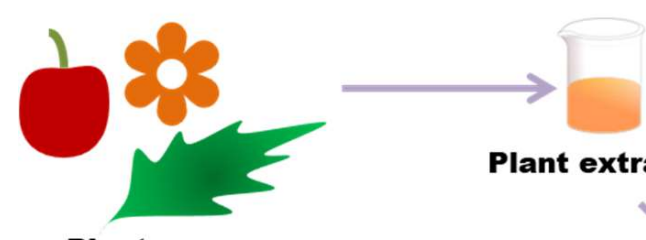

Plant extracts

Salt solution (metal ion)

Plant sources

Magnetic stirrer at $80^{\circ} \mathrm{C}$

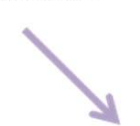
(HAucl4, Aucl3)

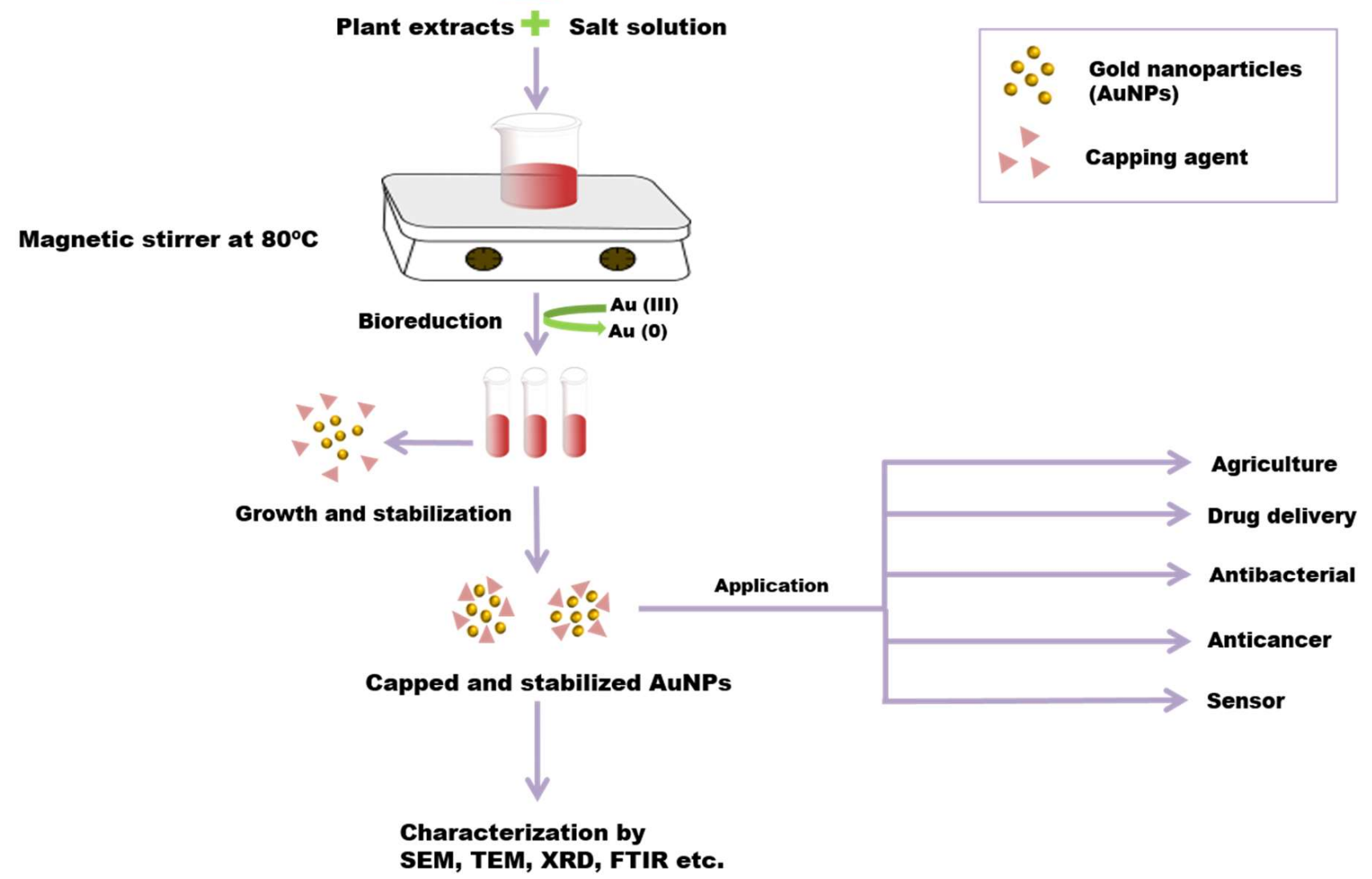

Figure 3. Green synthesis of AuNPs from a plant. Plant extract and metal salt solution $\mathrm{HAuCl}_{4}$ were mixed. After that, the resultant solution is centrifuged, which results in the bio reduction of metallic ions to AuNPs. Phytochemicals act as reducing, as well as stabilizing/capping, agents in this process. The resultant AuNPs are characterized by using SEM, TEM, FTIR, XRD, etc.

Synthesized AuNPs were initially identified in the change in reaction colour (formation of red colour) through UV-vis spectrophotometer analysis. DLS, XRD and SAED confirmed the crystalline structure of gold nanoparticles, and the size, shape and distribution of nanoparticles were visualized by TEM image. Based on FTIR analysis, it can be confirmed that functional groups such as $-\mathrm{C}-\mathrm{O}-\mathrm{C}-,-\mathrm{C}-\mathrm{O}-,-\mathrm{C}=\mathrm{C}-$, and $-\mathrm{C}=\mathrm{O}$ are the capping ligands of the nanoparticles [83]. Different plant parts are used as a source for AuNP biosynthesis. Some green synthesized AuNPs from various plant parts are listed in Table 2. 
Table 2. Green synthesis of Gold Nanoparticles (AuNPs) from different plants.

\begin{tabular}{|c|c|c|c|c|c|c|c|}
\hline Plant & Plant Part & Reactive Compound & Salt Solution & Size (nm) & Shape & Characterization & References \\
\hline $\begin{array}{l}\text { Artemisia vulgaris } \\
\text { (Mugwort) }\end{array}$ & Leaves & $\begin{array}{l}\text { Polyphenols, flavonoids, } \\
\text { terpenoids }\end{array}$ & $\mathrm{HAuCl}_{4}$ & $50-100$ & $\begin{array}{l}\text { Spherical, triangular, } \\
\text { hexagonal }\end{array}$ & $\begin{array}{l}\text { UV-vis Spectroscopy, XRD, } \\
\text { FT-IR, DLS, ZP, TEM and } \\
\text { EDX. }\end{array}$ & {$[84]$} \\
\hline $\begin{array}{l}\text { Clitoria ternatea } \\
\text { (Asian } \\
\text { pigeonwings) }\end{array}$ & Leaves & $\begin{array}{l}\text { Alcoholic, amine groups, halo } \\
\text { compounds }\end{array}$ & $\mathrm{HAuCl}_{4}$ & 100 & Rod & $\begin{array}{l}\text { UV-vis spectroscopy, FTIR, } \\
\text { XRD, TEM, EDX }\end{array}$ & [85] \\
\hline $\begin{array}{l}\text { Murraya koenigii Spreng } \\
\text { (Curry leaves) }\end{array}$ & Leaves & $\begin{array}{l}\text { Polyphenols, quercetin, } \\
\text { quercetin-3-glucoside, } \\
\text { flavonoids }\end{array}$ & $\mathrm{HAucl}_{4}$ & $20-40$ & Spherical & $\begin{array}{c}\text { XRD, EDX, FT-IR, HPLC, } \\
\text { TEM, UV-vis spectra, } \\
\text { Fluorescence microscopy. }\end{array}$ & [86] \\
\hline $\begin{array}{c}\text { Artocarpus } \\
\text { hirsutus (Wild jack) }\end{array}$ & Leaves & $\begin{array}{l}\text { Polyphenols, flavonoids, } \\
\text { terpenoids }\end{array}$ & $\mathrm{HAuCl}_{4}$ & $5-40$ & Spherical & $\begin{array}{l}\text { XRD, UV-visible spectra, } \\
\text { FT-IR and TEM }\end{array}$ & [87] \\
\hline $\begin{array}{l}\text { Justicia glauca (Thaasi } \\
\text { murungai) }\end{array}$ & Leaves & $\begin{array}{c}\text { Lignans[(+) pinoresinol, } \\
\text { (+)-medioresinol], alkaloids, } \\
\text { flavonoids, } \\
\text { steroids } \\
\text { (sitosterol-3-0-glucoside), } \\
\text { terpenoids }\end{array}$ & $\mathrm{HAuCl} \cdot 3 \mathrm{H}_{2} \mathrm{O}$ & 32 & Hexagonl, spherical & $\begin{array}{l}\text { UV-vis spectral analysis. } \\
\text { X-ray, XRD, TEM, FTIR, } \\
\text { EDX, CV, DPV. }\end{array}$ & [88] \\
\hline $\begin{array}{l}\text { Terminalia arjuna (Arjun } \\
\text { tree) }\end{array}$ & Leaves & $\begin{array}{c}\text { Arjunetin, leucoanthoc-yanidins, } \\
\text { hydrolyzable tannins }\end{array}$ & $\mathrm{HAuCl}_{4}$ & $20-25$ & Spherical & $\begin{array}{l}\text { UV-visible spectra, FT-IR, } \\
\text { XRD, AFM and TEM }\end{array}$ & [89] \\
\hline Mangifera indica & Leaves & $\begin{array}{l}\text { Terpenoids, flavonoids, } \\
\text { thiamine }\end{array}$ & $\mathrm{HAuCl}_{4} \cdot 3 \mathrm{H}_{2} \mathrm{O}$ & $17-20$ & Spherical & UV-vis, TEM and XRD. & [91] \\
\hline Olive & Leaves & $\begin{array}{l}\text { Proteins, oleoropein, } \\
\text { apigenin-7-glucoside, } \\
\text { luteolin-7-glucoside }\end{array}$ & $\mathrm{HAuCl}_{4} \cdot 3 \mathrm{H}_{2} \mathrm{O}$ & $50-100$ & $\begin{array}{c}\text { Triangular, spherical, } \\
\text { hexagonal }\end{array}$ & $\begin{array}{c}\text { UV-vis spectroscopy, } \\
\text { photoluminescence, TEM, } \\
\text { XRD, FTIR and } \\
\text { thermogravimetric analysis. }\end{array}$ & [92] \\
\hline $\begin{array}{l}\text { Coreopsis } \\
\text { lanceolate }\end{array}$ & Leaves & $\begin{array}{l}\text { Antioxidants like sugars, } \\
\text { flavonoids }\end{array}$ & $\mathrm{HAuCl}_{4}$ & $20-30$ & $\begin{array}{l}\text { Spherical, quasi } \\
\text { spherical }\end{array}$ & $\begin{array}{l}\text { UV-vis spectroscopy, TEM } \\
\text { and spectro fluorimetry }\end{array}$ & [93] \\
\hline $\begin{array}{l}\text { Cassia auriculata } \\
\text { (Matura tea tree) }\end{array}$ & Leaves & Polysaccharides, flavonoids & $\begin{array}{l}\mathrm{AuCl}_{3} \\
\mathrm{Au}_{2} \mathrm{Cl}_{6}\end{array}$ & $15-25$ & $\begin{array}{l}\text { Spherical, triangular, } \\
\text { hexagonal }\end{array}$ & $\begin{array}{l}\text { X-ray diffraction, TEM, } \\
\text { SEM-EDAX, FT-IR and } \\
\text { visible absorption } \\
\text { spectroscopy. }\end{array}$ & [94] \\
\hline
\end{tabular}


Table 2. Cont.

\begin{tabular}{|c|c|c|c|c|c|c|c|}
\hline Plant & Plant Part & Reactive Compound & Salt Solution & Size $(\mathrm{nm})$ & Shape & Characterization & References \\
\hline $\begin{array}{c}\text { Lonicera Japonica } \\
\text { (Japanese } \\
\text { honeysuckle) }\end{array}$ & Flower & Amino acids & $\mathrm{AgNO}_{3}, \mathrm{HAuCl}_{4}$ & 8 & $\begin{array}{l}\text { Triangular } \\
\text { tetrahedral }\end{array}$ & $\begin{array}{c}\text { UV-vis spectrophotometer, } \\
\text { FTIR, XRD, EDX, SEM and } \\
\text { HRTEM. }\end{array}$ & [95] \\
\hline $\begin{array}{c}\text { Nyctanthes } \\
\text { arbortristis (Night } \\
\text { flowering } \\
\text { jasmine) }\end{array}$ & Flower & alkaloids, flavonoids & $\mathrm{HAuCl}_{4}$ & $15-25$ & Spherical & $\begin{array}{l}\text { UV-vis spectro photometer, } \\
\text { TEM, XRD, FTIR, NMR. }\end{array}$ & [96] \\
\hline $\begin{array}{l}\text { Guazuma } \\
\text { ulmifolia (Bay } \\
\text { cedar) }\end{array}$ & Bark & $\begin{array}{l}\text { Tannins, proanthocya-nidins, } \\
\text { precocene, catechins. }\end{array}$ & $\begin{array}{l}\mathrm{HAuCl}_{4} \cdot 3 \mathrm{H}_{2} \mathrm{O} \\
\mathrm{AgNO}_{3}\end{array}$ & $20-25$ & Spherical & $\begin{array}{l}\text { UV-vis spectroscopy, FT-IR, } \\
\text { XRD, AFM and HR-TEM } \\
\text { analyses }\end{array}$ & [97] \\
\hline $\begin{array}{c}\text { Salix } \\
\text { (Willow tree) }\end{array}$ & Bark & $\begin{array}{l}\text { Tannins, alkanoids, flavonoids, } \\
\text { alkaloids. }\end{array}$ & $\mathrm{AuCl}_{4} \mathrm{H}_{9} \mathrm{O}_{4}$ & 15 & Spherical & $\begin{array}{l}\text { UV-vis spectroscopy, XRD, } \\
\text { TEM, and HR-TEM. }\end{array}$ & [98] \\
\hline $\begin{array}{l}\text { Acacia nilotica } \\
\text { (Gum Arabic } \\
\text { tree) }\end{array}$ & Bark & $\begin{array}{c}\text { Protein, phenols, tannins, } \\
\text { terpenoids, } \\
\text { saponins }\end{array}$ & $\mathrm{HAuCl}_{4} \cdot 3 \mathrm{H}_{2} \mathrm{O}$ & $10-15$ & $\begin{array}{l}\text { Unshaped, } \\
\text { quasispherical }\end{array}$ & $\begin{array}{l}\text { UV-vis spectroscopy, XRD, } \\
\text { EDX, TEM, FTIR, DPV. }\end{array}$ & [99] \\
\hline $\begin{array}{l}\text { Musa paradisiaca } \\
\text { (Banana) }\end{array}$ & Peel & $\begin{array}{c}\text { Phenolic compounds, } \\
\text { gallocatechin, } \\
\text { dopamine }\end{array}$ & $\mathrm{HAuCl}_{4}$ & 50 & Spherical & $\begin{array}{l}\text { UV-vis spectroscopy, FTIR, } \\
\text { XRD, TEM, Zeta potential } \\
\text { analysis and EDX. }\end{array}$ & {$[100]$} \\
\hline $\begin{array}{l}\text { Terminalia arjuna } \\
\text { (Arjun tree) }\end{array}$ & Peel & Polyphenols & $\mathrm{HAuCl}_{4}$ & 60 & $\begin{array}{l}\text { Triangular hexagonal } \\
\text { pentagonl }\end{array}$ & $\begin{array}{l}\text { UV spectroscopy, HRTEM, } \\
\text { XRD, FESEM, EDX, DLS, } \\
\text { and zeta potential analyses. }\end{array}$ & [102] \\
\hline $\begin{array}{l}\text { Lantana camara } \\
\text { (Wild sage) }\end{array}$ & Fruit & $\begin{array}{c}\text { Ursolic acid, iridoid glycosides, } \\
\text { monoand } \\
\text { sesquiterpe-nes, flavonoids }\end{array}$ & $\mathrm{HAuCl}_{4}$ & $150-300$ & Triangular & $\begin{array}{l}\text { UV-vis-NIR, TEM, SAED, } \\
\text { DLS, and XRD techniques. }\end{array}$ & [103] \\
\hline $\begin{array}{l}\text { Citrus (Lemon, } \\
\text { tangerine, orange) }\end{array}$ & Fruit & Citric acid, proteins & $\mathrm{HAuCl}_{4}$ & $\begin{array}{l}32.3,43.4 \\
56.7\end{array}$ & Spherical, triangular & $\begin{array}{l}\text { UV-visible spectra. TEM } \\
\text { XRD, SEAD, DLS. }\end{array}$ & [104] \\
\hline $\begin{array}{l}\text { Citrus maxima } \\
\text { (Pomelo) }\end{array}$ & Fruit & $\begin{array}{l}\text { Polypeptides/proteins, terpene, } \\
\text { ascorbic acid }\end{array}$ & $\mathrm{HAuCl}_{4} \cdot 4 \mathrm{H}_{2} \mathrm{O}$ & $15-35$ & Spherical & $\begin{array}{l}\text { UV-vis spectroscopy, SEM, } \\
\text { XRD and FTIR. }\end{array}$ & [105] \\
\hline Pear & Fruit & Sugars, amino acids, proteins & $\mathrm{HAuCl}_{4}$ & $20-400$ & $\begin{array}{l}\text { Triangular hexago- } \\
\text { nalpolyhedral }\end{array}$ & $\begin{array}{l}\text { UV-vis spectroscopy, TEM, } \\
\text { AFM, XRD, XPS, EDAX. }\end{array}$ & [106] \\
\hline $\begin{array}{l}\text { Sterculia } \\
\text { acuminate (Pola } \\
\text { plant) }\end{array}$ & Fruit & Phenolic compounds & $\mathrm{HAuCl}_{4}$ & $9.37-38.12$ & Spherical & $\begin{array}{l}\text { TEM, X-ray diffraction, } \\
\text { UV-vis spectroscopy and } \\
\text { FTIR, and X-ray } \\
\text { photoelectron spectrometry. }\end{array}$ & [107] \\
\hline
\end{tabular}


Table 2. Cont

\begin{tabular}{|c|c|c|c|c|c|c|c|}
\hline Plant & Plant Part & Reactive Compound & Salt Solution & Size (nm) & Shape & Characterization & References \\
\hline $\begin{array}{c}\text { Pistacia } \\
\text { integerrima } \\
\text { (Zebra wood) }\end{array}$ & Galls & $\begin{array}{c}\text { Monoterpenes, triterpenoids, } \\
\text { sterols, } \\
\text { dihydromal-valic acid. }\end{array}$ & $\mathrm{HAuCl}_{4} \cdot 3 \mathrm{H}_{2} \mathrm{O}$ & 20-200 & Grain-like & $\begin{array}{l}\text { UV-vis spectroscopy, FTIR } \\
\text { and SEM. }\end{array}$ & [108] \\
\hline $\begin{array}{c}\text { Abelmoschus } \\
\text { esculentus (Okra) }\end{array}$ & Seed & $\begin{array}{l}\text { Proteins, polysaccharides, } \\
\text { glycoprotein }\end{array}$ & $\mathrm{HAuCl}_{4}$ & $45-75$ & $\begin{array}{l}\text { Spherical, uneven } \\
\text { shape }\end{array}$ & $\begin{array}{l}\text { UV-visible spectroscopy, } \\
\text { XRD, FTIR, AFM, FESEM } \\
\text { and EDX. }\end{array}$ & [109] \\
\hline $\begin{array}{l}\text { Theobromo } \\
\text { cacao } \\
\text { (Cocoa) }\end{array}$ & Seed & Polyphenols & $\mathrm{HAuCl}_{4}$ & $150-200$ & Spherical & $\begin{array}{c}\text { UV-vis-NIR } \\
\text { spectrophotometer, SPR, } \\
\text { TEM, XRD, FTIR, XPS }\end{array}$ & [110] \\
\hline $\begin{array}{c}\text { Hevea } \\
\text { brasiliensis } \\
\text { (Para rubber } \\
\text { tree) }\end{array}$ & Latex & isoprene, proteins & $\mathrm{AuCl}_{3}, \mathrm{Au}_{2} \mathrm{Cl}_{6}$ & 50 & Spherical, triangular & $\begin{array}{l}\text { UV-vis spectroscopy, SEM, } \\
\text { TG/FT-IR, XED. }\end{array}$ & [111] \\
\hline $\begin{array}{l}\text { Zingiber officinale } \\
\text { (Ginger) }\end{array}$ & Rhizome & $\begin{array}{c}\text { Oxalic acid, ascorbic acid, } \\
\text { Phenylpropanoids, zingerone. }\end{array}$ & $\mathrm{HAuCl}_{4}, \mathrm{AgNO}_{3}$ & $10-20$ & $\begin{array}{c}\text { Spherical, triangular, } \\
\text { truncated triangular, } \\
\text { hexagonal }\end{array}$ & $\begin{array}{l}\text { UV-visible spectroscopy, } \\
\text { SEM-EDS, TEM, XRD, FTIR. }\end{array}$ & [112] \\
\hline $\begin{array}{l}\text { Curcuma longa } \\
\text { (Turmeric) }\end{array}$ & Rhizome & $\begin{array}{l}\text { Phenolic (curcumin), } \\
\text { triterpenoids, alkaloid, sterols. }\end{array}$ & $\begin{array}{l}\mathrm{HAuCl}_{4} \\
\mathrm{AgNO}_{3}\end{array}$ & $5-60$ & Oblong spherical & $\begin{array}{l}\text { UV-vis spectroscopy, XRD, } \\
\text { TEM, HR-TEM, } \\
\text { thermogravimetric analysis. }\end{array}$ & [113] \\
\hline $\begin{array}{l}\text { Acorus calamus } \\
\text { (Sweet flag) }\end{array}$ & Rhizome & $\begin{array}{l}\text { Asarone, caryophyllene, } \\
\text { isoasarone, methyl isoeugenol, } \\
\text { safrole. }\end{array}$ & $\mathrm{HAuCl}_{4} \cdot 3 \mathrm{H}_{2} \mathrm{O}$ & 10 & Spherical & $\begin{array}{l}\text { UV-visible spectral analysis, } \\
\text { XRD and FT-IR, SPR, } \\
\text { HR-TEM, SEM with EDAX. }\end{array}$ & {$[115,116]$} \\
\hline $\begin{array}{l}\text { Acacia nilotica } \\
\text { (Gum Arabic } \\
\text { tree) }\end{array}$ & Bark & $\begin{array}{c}\text { Protein, phenols, tannins, } \\
\text { terpenoids, } \\
\text { Saponins. }\end{array}$ & $\mathrm{HAuCl}_{4} \cdot 3 \mathrm{H}_{2} \mathrm{O}$ & $10-50$ & $\begin{array}{l}\text { Unshaped, } \\
\text { quasispherical. }\end{array}$ & $\begin{array}{l}\text { UV-vis spectroscopy, XRD, } \\
\text { TEM, EDX, DPV and FTIR. }\end{array}$ & [99] \\
\hline $\begin{array}{l}\text { Guazuma } \\
\text { ulmifolia (Bay } \\
\text { cedar) }\end{array}$ & Bark & $\begin{array}{l}\text { Tannins, proanthocya-nidins, } \\
\text { precocene, catechins. }\end{array}$ & $\begin{array}{c}\mathrm{HAuCl} l_{4} \cdot 3 \mathrm{H}_{2} \mathrm{O} \text { and } \\
\mathrm{AgNO}_{3}\end{array}$ & $20-25$ & Spherical & $\begin{array}{l}\text { UV-vis spectroscopy, FT-IR, } \\
\text { XRD, AFM and HR-TEM } \\
\text { analyses. }\end{array}$ & [97] \\
\hline $\begin{array}{l}\text { Areca catechu } \\
\text { (Pinang palm) }\end{array}$ & Nut & $\begin{array}{l}\text { Polyphenols, fats, proteins, } \\
\text { carbohydrate, flavonoids. }\end{array}$ & $\mathrm{HAuCl}_{4}$ & 13.70 & Spherical & $\begin{array}{l}\text { UV-visible, TEM, XRD, and } \\
\text { FTIR. }\end{array}$ & [117] \\
\hline
\end{tabular}


Table 2. Cont

\begin{tabular}{|c|c|c|c|c|c|c|c|}
\hline Plant & Plant Part & Reactive Compound & Salt Solution & Size (nm) & Shape & Characterization & References \\
\hline $\begin{array}{c}\text { Momordica } \\
\text { Cochinchinensis. }\end{array}$ & Biomass & Proteins & $\mathrm{HAuCl}_{4}$ & $10-80$ & $\begin{array}{l}\text { Spherical, oval, } \\
\text { triangular }\end{array}$ & $\begin{array}{l}\text { UV-visible, FT-IR, XRD, } \\
\text { TEM, SPR and EDX }\end{array}$ & [118] \\
\hline $\begin{array}{c}\text { Palm oil } \\
\text { mill effluent }\end{array}$ & Palm oil & $\begin{array}{l}\text { Proteins, flavonoids, reducing } \\
\text { sugars, alkaloids }\end{array}$ & $\mathrm{HAuCl}_{4} \cdot 3 \mathrm{H}_{2} \mathrm{O}$ & $13-25$ & Spherical & $\begin{array}{l}\text { UV-vis spectroscopy, TEM, } \\
\text { XRD, and FTIR. }\end{array}$ & [119] \\
\hline $\begin{array}{c}\text { Macrotylomauniflorum } \\
\text { (Horse } \\
\text { gram) }\end{array}$ & $\begin{array}{l}\text { Whole } \\
\text { plant }\end{array}$ & $\begin{array}{l}\text { Proteins, carbohydrate, } \\
\text { antioxidant }\end{array}$ & $\mathrm{HAuCl}_{4} \cdot 3 \mathrm{H}_{2} \mathrm{O}$ & $14-17$ & Spherical & $\begin{array}{l}\text { UV-visible spectroscopy, } \\
\text { TEM, XRD and FTIR } \\
\text { analysis. }\end{array}$ & [120] \\
\hline
\end{tabular}




\subsection{Advantages and Limitations of the Synthesis Methods}

Chemical methods for the synthesis of AuNPs have many limitations, which include environmental and biocompatibility concerns. Some of the chemicals used in the synthesis of gold nanoparticles during chemical synthesis can affect our environment and are the cause of risks for administering them into living organisms, thus limiting the biological applications of such AuNPs [121]. Therefore, various biological methods have been devised for the synthesis of AuNPs to limit these concerns. The green synthesis of AuNPs is a simple, safe, dynamic and facile process as its protocol follows a moderate environment without extreme temperatures or pressures. It is a cost-effective, rapid, environmentally benign, and biocompatible process, thus safe for clinical research. AuNPs are being synthesized through different physicochemical methods [122]. However, biogenic reduction of the gold salt to synthesize AuNPs is an inexpensive, eco-friendly and safe process. Neither toxic chemicals, such as sodium borohydride $\mathrm{NaBH}_{4}$, are used, nor are any contaminants or harmful/dangerous by-products produced in this process. Moreover, a considerable number of AuNPs of controlled size and morphology can be easily synthesized. Their stability and reduction potential are attributed to bioactive molecules present in these biological resources. Green synthesized AuNPs application improves the diagnosis and treatment of many human diseases [78]. Out of many biological resources, plant extracts are reported to be a more beneficial resource. Various plant metabolites, such as alkaloids, polyphenols (catechin, flavones, taxifolin, catechin and epicatechin, and phenolic acids), alcoholic compounds, glutathiones, polysaccharides, antioxidants, organic acids (ascorbic, oxalic, malic, tartaric, and protocatechuic acid), quinones, proteins, and amino acids are involved in the formation of NPs by the reduction of metal ions. FT-IR and HPLC tests were used to indicate the presence of these capping agents in the synthesized NPs [76]. Therefore, in this prospect, using plant sources for Au NPs synthesis can open new horizons in future. The primary goal of green nanotechnology is to curtail forthcoming environmental and human health risks associated with the use of nanotechnology products and inspire the substitution of existing products with a more environmentally friendly nano-product. AuNPs synthesis through this green method can contribute to other fields such as green photocatalyst, drug delivery, anti-microorganism, adsorbent, detector, and green separation science and technology [77]. The green synthesis of AuNPs from bacteria is a slow process, so the synthesis process can take a long time, comprising hours and even days. Green synthesis from fungi is better than the previous one, as fungi produce a large number of proteins and reactive compounds. As a result, the reaction process can be scaled up using fungi as a source $[116,123]$. Although green synthesis of AuNPs from the plant has many advantages, the limitation of using a plant as a source for the synthesis of AuNPs is that the identification of reactive components is difficult as plant biomass comprises a large number of organic components $[124,125]$. Biomolecules in the plant source contain various functional groups, which can play an essential role in synthesizing AuNPs, but different biomaterials show different reducing abilities. So, it is crucial to first determine their reducing ability before using them in the synthesis reaction [126,127].

\subsection{Plant-Based Synthesized Gold Nanoparticles as Anticancer Agents}

Increasing nanotechnology applications have gained broad attention in various sectors in recent years, but not restricted to medical, cosmetics, medical devices, electrical and electronic, drugs, food and packaging [128]. The most promising approach in nanotechnology is to develop nanomaterials for use in healthcare. In recent years, it has been observed that nanomaterials, such as gold nanoparticles (AuNPs), are of great interest to humans due to their wide range of uses in agriculture, remediation, medicine, health aspects, industry, pharmaceuticals, etc. [129]. Preliminary studies have shown that green synthesized AuNPs have various biological functions, such as antimicrobial, antiviral, anti-inflammatory, antioxidant and anticancer activity. In recent years, the use of plant-derived AuNPs has brought significant advances in cancer diagnosis and treatment, although some work in 
this area began mainly a few decades ago [128]. Notably, studies have demonstrated the usefulness of AuNPs as anticancer agents, in addition to photothermal agents, contrast agents and drug carriers. However, there are no previous literature reports on the molecular mechanism of tumour inhibition mediated by plant AuNPs. A recent resurgence of the anticancer effects of AuNPs from plant extracts has taken great strides so far. Despite these encouraging advances, more research is needed to understand the molecular consequences in cancer therapy, such as cellular toxicity, mitochondrial toxicity, apoptosis, necrosis and the production of reactive oxygen species (ROS). Several studies and reviews have been undertaken to investigate the anti-cancer potential of green synthesized AuNPs from different plant species. Scholars have reported on the green synthesis of AuNPs from several important plants and their applicability in various biomedical applications [130]; in this context, other authors have also proposed the implication of biosynthesized AuNPs in various applications. Researchers have reported on the aqueous and ethanolic extract of Taxus baccata synthesized nanostructure AuNPs. They were characterized by different techniques, such as UV-Vis spectroscopy, TEM, SEM and FT-IR. The MTT assay was performed to examine the anticancer activity of colloidal AuNPs on cell lines, such as Caov-4, MCF-7 and HeLa. In addition, an in vitro experiment on cell exposure to T. baccata-mediated AuNPs confirms the caspase-independent death program as an anti-cancer mechanism with increased efficacy for cancer therapy. This issue has been explored using flow-cytometry and real-time PCR [37]. Many plants (Camellia sinensis, Coriandrum sativum, Mentha arvensis, Phyl-lanthus amarus, Artabotrys hexapetalus, Mimusops elengi, Syzygium aromaticum) were described by Priya and Iyer, which showed that the green synthesized AuNPs have anticancer activity against the human breast cancer cell line, i.e., MCF7 and found that AuNPs at a minimum concentration of $2 \mu \mathrm{g} / \mathrm{mL}$ for cancer therapy are as effective as standard drugs. Moreover, the increase in the nanoparticle concentration is directly proportional to the effectiveness against cancer [131]. The increasing demand for biosynthesized gold nanoparticles has been greatly facilitated in medical applications, particularly in targeted drug delivery, one of the most recent advances in nanotechnology. Further studies have shown that the use of the Dysosma pleiantha rhizome can improve cancer therapy, which has been proven experimentally by tracking the biosynthesized AuNPs using an aqueous extract. The morphological characteristics of AuNPs are spherical with an average size of $127 \mathrm{~nm}$, characterized by various techniques, such as UV-Vis spectroscopy, FT-IR, scanning electron microscopy (SEM) and transmission electron microscopy (TEM). In addition, they also suggested the promising role of biosynthesized AuNPs with enhanced activity against cell proliferation. Finally, they concluded that the D. pleiantha rhizome has antimetastatic potential by interfering with the microtubule polymerization in the human fibrosarcoma cell line HT-1080 [132]. It is clear from the previous research that green synthesized AuNPs holds better choice over other methods because of their cost-effectiveness, non-toxicity and feasibility in cancer therapy. However, this theory is backed up by the evidence in Virmani et al., from which the author concludes that biosynthesized nanoparticles have potential antitumor activity compared to chemically synthesized nanoparticles. They reviewed available methods that could be used to predict anticancer activity against many cancerous (HeLa, MCF-7, A549 and H1299) and normal (HEK293) cell lines. The extract derived from Ocimum tenuiflorum in the cell viability assay illustrates that biosynthesized AuNPs at lower concentrations were more pronounced and non-toxic, compared to HEK293, which can effectively inhibit the growth of various cancer cell lines with an $\mathrm{IC}_{50}$ value of $200 \mu \mathrm{g} / \mathrm{mL}$. In contrast, the analysis shows that chemically synthesized nanoparticles have contributed negatively to anti-cancer properties even at high concentrations. The results conclude that the use of the chemically synthesized nanoparticles method for cancer therapy offers no obvious advantage [133]. Researchers have reported in their study that the internalization of AuNPs using the extract of Allium cepa was non-toxic to cells. Allium cepa has various pharmacological properties, including anti-cancer activity; however, over the past year, Allium cepa-derived nanoparticles have been of utmost importance in healthcare [134]. Moreover, some important applications of green synthesized AuNPs as an anti-cancer 
agent are summarized in Table 1. Mostly, the chemically synthesized gold nanoparticles (AuNPs) have been extensively exploited to date; only a few studies have been reported for plant-based green synthesized AuNP in vivo therapy, toxicity, and biodistribution. A study reported that green synthesized gold nanoparticles using leaf extract of Peltophorum pterocarpum $(P P)$ for doxorubicin delivery both in vitro and in vivo in the C57BL6/J female mice. Administration of biosynthesized doxorubicin-loaded (b-Au-PP-Dox) drug delivery system displayed the significant inhibition of cancer cell growth (A549, B16F10) in vitro as well as inhibition of tumour growth in vivo model compared to free doxorubicin and untreated one [135]. Similarly, leaf extracts of Mentha piperita-generated AuNPs were tested against MDA-MB-231 and A549, and normal 3T3-L1 cell lines in vitro, as well as the anti-inflammatory and analgesic activities, were studied on a Wistar rat model. AuNPs showed significant anticancer activities in vitro. However, the in vivo analysis gave positive results for both the activities with less potency as compared to the standard drugs, which suggests that AuNPs might be used in combination with standard drugs to enhance their efficacy [136]. These aforementioned novel in vivo studies have set a new frontier for the potential use of plant-based AuNPs for therapy and drug delivery systems as a costeffective and eco-friendly approach in the near future. Multifunctionality is the key factor of nanovectors in cancer-specific therapy. Combinatorial therapy with phytoconstituents in cancer therapy has been thoroughly investigated and well documented in the present scenario. More recently, a re-evaluation of this concept has led to the use of a combination of phytochemicals which have been under constant investigation and are particularly used as potent natural anti-cancer agents. This was introduced to overcome some inherent limitations on toxicity, specificity, hazardous and reduced action. The anticancer activity on various cancer cell lines by AuNPs synthesized by using plant extracts are depicted in Table 3. 
Table 3. Showing anticancer activity of gold nanoparticles using plant extracts and characterization technique.

\begin{tabular}{|c|c|c|c|c|c|c|c|}
\hline Sl No. & Plant & Extract Used & Anticancer Activity Type & Characterization & Shape & Size & References \\
\hline 1 & $\begin{array}{l}\text { Brazilian Red } \\
\text { Propolis }\end{array}$ & $\begin{array}{c}\text { Hydroethanolic } \\
\text { extract }\end{array}$ & $\begin{array}{l}\text { Bladder (T24) and prostate } \\
\text { (PC-3) cancer cell line }\end{array}$ & $\begin{array}{l}\text { SPR, UV-Vis spectroscopy, } \\
\text { NTA, TEM, EDXS, SAED, } \\
\text { FTIR, TGA, }\end{array}$ & Spherical & $8-15 \mathrm{~nm}$ & [137] \\
\hline 2 & Abies spectabilis & Aqueous extract & Bladder cancer T24 cell line & $\begin{array}{c}\text { TEM, SAED, UV-visible } \\
\text { spectroscopy, EDX, FTIR, } \\
\text { AFM, XRD }\end{array}$ & Spherical & 20-200 nm & [138] \\
\hline 3 & Benincasa hispida & Aqueous extract & $\begin{array}{l}\text { HeLa cells and normal } \\
\text { osteoblasts cell line }\end{array}$ & $\begin{array}{l}\text { UV-Visible Spectroscopy, } \\
\text { DLS, Zeta sizer, TEM, FTIR }\end{array}$ & Spherical & $22.18 \pm 2 \mathrm{~nm}$ & [29] \\
\hline 5 & orchid & $\begin{array}{l}\text { Orchid plant } \\
\text { extract(whole) }\end{array}$ & $\begin{array}{l}\text { Breast cancer AMJ } 13 \text { cell } \\
\text { lines }\end{array}$ & $\begin{array}{c}\text { UV-Vis spectroscopy, TEM, } \\
\text { AFM, FTIR }\end{array}$ & Spherical & $14-50 \mathrm{~nm}$ & [140] \\
\hline 6 & Taxus baccata & Ethanolic extract & $\begin{array}{l}\text { Breast (MCF7), cervical } \\
\text { (HeLa), ovarian (Caov-4) } \\
\text { cancer cell line }\end{array}$ & $\begin{array}{l}\text { UV-Vis spectroscopy, TEM, } \\
\text { Zetasizer, FTIR, EDX, AFM }\end{array}$ & $\begin{array}{c}\text { Spherical, } \\
\text { semispherical, } \\
\text { hexagonal, triangular }\end{array}$ & $20 \mathrm{~nm}$ & [37] \\
\hline 7 & $\begin{array}{l}\text { Marsdenia } \\
\text { tenacissima }\end{array}$ & Leaf extract & A549 lung cell line & $\begin{array}{c}\text { UV-vis, spectroscopy, AFM, } \\
\text { EDS, TEM, FTIR, XRD, } \\
\text { SAED }\end{array}$ & Spherical, anisotropic & $50 \mathrm{~nm}$ & [141] \\
\hline 8 & $\begin{array}{l}\text { Argemone } \\
\text { mexicanaL. }\end{array}$ & Aqueous extract & $\begin{array}{l}\text { Human colon cancer cell } \\
\text { line, HCT-15 }\end{array}$ & TEM, XRD, FTIR & Hexagonal & $20-40 \mathrm{~nm}$ & [142] \\
\hline 9 & $\begin{array}{l}\text { Couroupita } \\
\text { guianensis }\end{array}$ & Aqueous extract & Leukemia cell line & $\begin{array}{l}\text { UV-vis spectroscopy, FTIR, } \\
\text { XRD, SEM, TEM }\end{array}$ & $\begin{array}{c}\text { Spherical, triangular, } \\
\text { tetragonal, } \\
\text { pentagonal }\end{array}$ & $7-48 \mathrm{~nm}$ & [143] \\
\hline 10 & Lycium chinense & Fruit extract & $\begin{array}{l}\text { Human breast cancer MCF7 } \\
\text { cell line and non-diseased } \\
\text { RAW264.7 (murine } \\
\text { macrophage) cells }\end{array}$ & $\begin{array}{l}\text { UV-vis spectroscopy, FTIR, } \\
\text { XRD, FETEM, EDX, SAED }\end{array}$ & $\begin{array}{l}\text { Poydispersed, } \\
\text { agglomerated }\end{array}$ & $20-100 \mathrm{~nm}$ & [144] \\
\hline 11 & Tabebuia argentiea & $\begin{array}{l}\text { Aqueous, flower } \\
\text { extracts }\end{array}$ & $\begin{array}{l}\text { Hepatic cells (Hep G2) cell } \\
\text { line }\end{array}$ & EDX, SEM & Spherical & $56 \mathrm{~nm}$ & [145] \\
\hline
\end{tabular}


Table 3. Cont

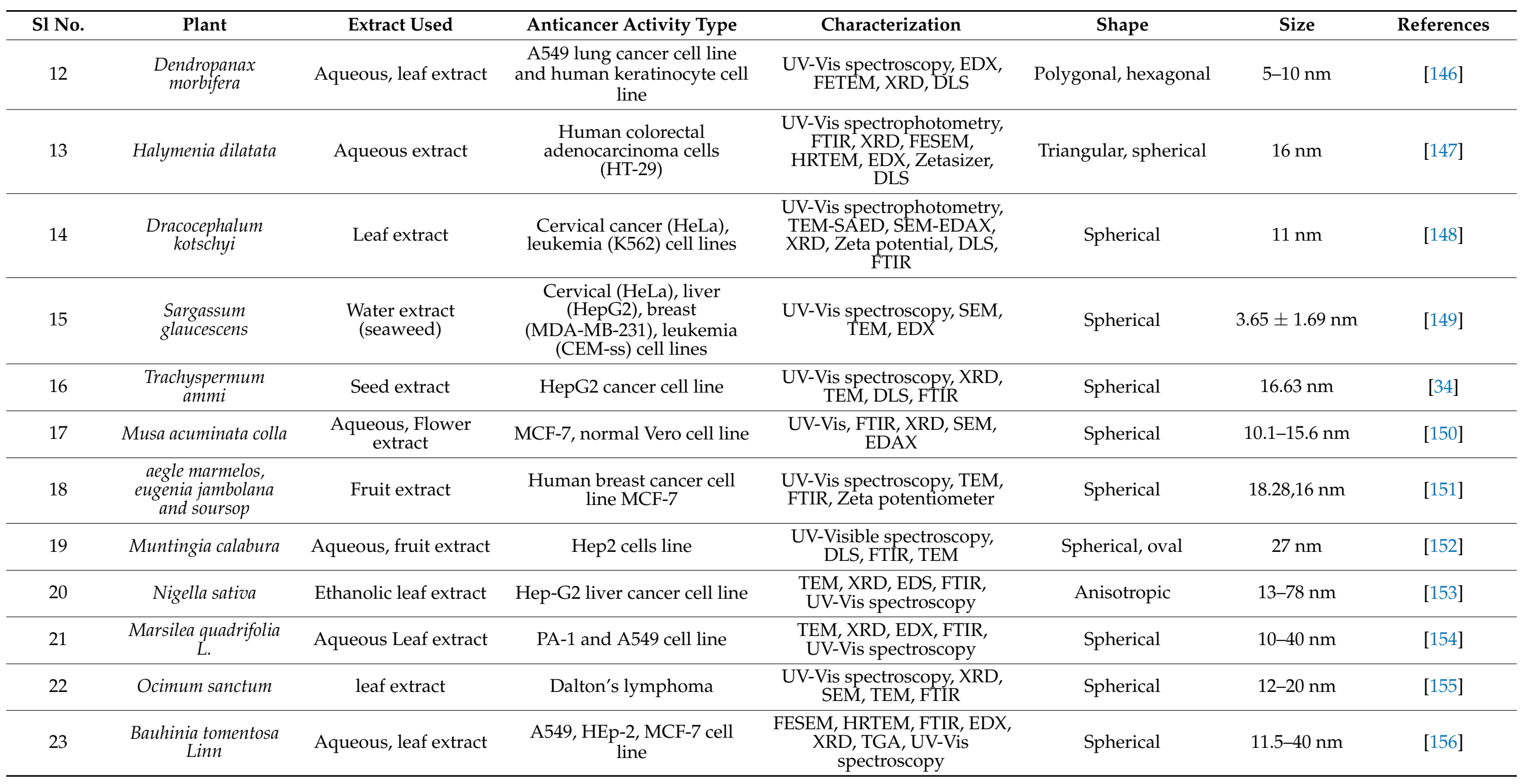


Table 3. Cont

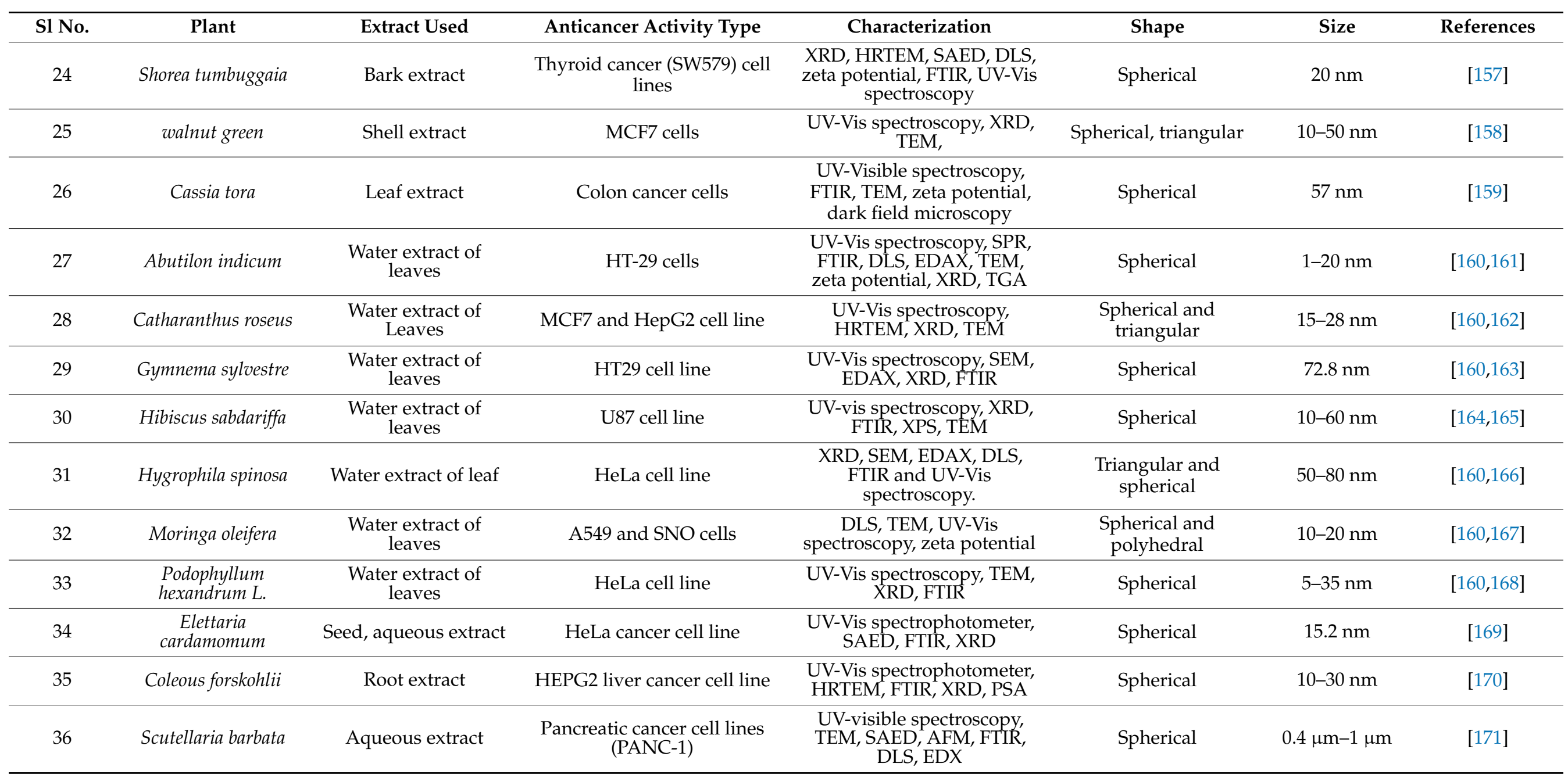


Table 3. Cont.

\begin{tabular}{|c|c|c|c|c|c|c|c|}
\hline S1 No. & Plant & Extract Used & Anticancer Activity Type & Characterization & Shape & Size & References \\
\hline 37 & $\begin{array}{l}\text { Sargassum } \\
\text { incisifolium }\end{array}$ & Aqueous extract & $\begin{array}{l}\text { HT-29, MCF-7 cancer cell } \\
\text { line, MCF-12a non cancer } \\
\text { cell line }\end{array}$ & $\begin{array}{c}\text { TEM, XRD, UV-Vis } \\
\text { spectroscopy, zeta potential, } \\
\text { FTIR, EDX, DLS, ICP-AES }\end{array}$ & Spherical & $12.38 \mathrm{~nm}$ & [172] \\
\hline 38 & Panax notoginseng & Leaf extract & PANC-1 cell line & $\begin{array}{l}\text { UV-Vis spectroscopy, TEM, } \\
\text { DLS, FTIR, AFM, SAED }\end{array}$ & $\begin{array}{l}\text { Hexagonal, spherical, } \\
\text { oval, triangular }\end{array}$ & $80-12 \mathrm{~nm}$ & [171] \\
\hline 39 & Antigonon leptopus & Leaf extract & $\begin{array}{l}\text { Human adenocarcinoma } \\
\text { breast cancer (MCF-7) cells }\end{array}$ & $\begin{array}{l}\text { UV-Vis spectroscopy, XRD, } \\
\text { SAED, FTIR, HRTEM, EDX }\end{array}$ & Spherical & $13-28 \mathrm{~nm}$ & [173] \\
\hline 40 & Mukia Maderaspatna & Aqueous, leaf extract & MCF 7 breast cancer cell line & $\begin{array}{l}\text { UV-Vis spectroscopy, EDAX, } \\
\text { SEM, TEM, FTIR }\end{array}$ & $\begin{array}{l}\text { Spherical, circular, } \\
\text { triangular }\end{array}$ & $20-50 \mathrm{~nm}$ & [174] \\
\hline 41 & Hevea brasiliensis & Latex extract & CHO-K1 cell line & $\begin{array}{l}\text { UV-Vis spectroscopy, XRD, } \\
\text { TEM, FTIR }\end{array}$ & spherical & $9 \mathrm{~nm}$ & [175] \\
\hline 42 & Lonicera 4 japonica & Flower extract & $\begin{array}{l}\text { Cervical cancer }(\mathrm{HeLa}) \text { cell } \\
\text { line }\end{array}$ & $\begin{array}{l}\text { UV-Vis spectroscopy, EDX, } \\
\text { XRD, GCMS, TEM, FTIR }\end{array}$ & $\begin{array}{c}\text { Polydisperse } \\
\text { (spherical, triangular, } \\
\text { hexagonal) }\end{array}$ & $10-40 \mathrm{~nm}$ & [176] \\
\hline 43 & $\begin{array}{l}\text { Anacardium } \\
\text { occidentale }\end{array}$ & Leaf extract & MCF-7 cell line & $\begin{array}{c}\text { UV-Vis spectroscopy, TEM, } \\
\text { XRD, FTIR }\end{array}$ & Spherical & $10-30 \mathrm{~nm}$ & [177] \\
\hline 44 & Sasa borealis & Aqueous, leaf extract & $\begin{array}{c}\text { AGS (Gastric } \\
\text { adenocarcinoma) cell line }\end{array}$ & $\begin{array}{l}\text { UV-Vis spectroscopy, TEM, } \\
\text { EDX, XRD, FTIR, GCMS }\end{array}$ & Oval, spherical & $10-30 \mathrm{~nm}$ & [178] \\
\hline 45 & Alternanthera Sessilis & Aqueous, leaf extract & $\begin{array}{l}\text { Cervical cancer (HeLa) cell } \\
\text { line }\end{array}$ & $\begin{array}{c}\text { UV-Vis spectroscopy, } \\
\text { HRTEM, EDX, SAED, AFM, } \\
\text { FTIR }\end{array}$ & Spherical & $20-40 \mathrm{~nm}$ & [179] \\
\hline 46 & Bauhinia purpurea & Aqueous, leaf extract & $\begin{array}{l}\text { Lung carcinoma cell line } \\
\text { (A549) }\end{array}$ & $\begin{array}{l}\text { UV-Vis spectroscopy, } \\
\text { HRTEM, SAED, XRD, EDX, } \\
\text { FTIR }\end{array}$ & Spherical, polygonal & 20-100 nm & [180] \\
\hline 47 & $\begin{array}{l}\text { Crassocephalum } \\
\text { rubens }\end{array}$ & Aqueous, leaf extract & MCF-7 and Caco-2 cells & $\begin{array}{c}\text { UV-Vis spectroscopy, TEM, } \\
\text { FTIR }\end{array}$ & Spherical & $20 \pm 5 \mathrm{~nm}$ & [181] \\
\hline 48 & Backhousia citriodora & Aqueous, leaf extract & $\begin{array}{l}\text { MCF-7 breast cancer cell line } \\
\text { and the HepG2 liver cancer } \\
\text { cell line }\end{array}$ & $\begin{array}{l}\text { UV-Vis spectroscopy, TEM, } \\
\text { zeta potential, XRD, FTIR }\end{array}$ & Spherical & $8.40 \pm 0.084 \mathrm{~nm}$ & [182] \\
\hline 49 & Petroselinum crispum & Aqueous, leaf extract & $\begin{array}{l}\text { Human cancerous colorectal } \\
\text { cell line }\end{array}$ & $\begin{array}{c}\text { UV-Vis spectroscopy, TEM, } \\
\text { EDX, FTIR.XRD }\end{array}$ & $\begin{array}{c}\text { Spherical, semi-rod } \\
\text { aggregates, } \\
\text { flower-shaped } \\
\text { nanoparticles }\end{array}$ & $20-80 \mathrm{~nm}$ & [183] \\
\hline 50 & Indigofera tinctoria & Aqueous, leaf extract & lung cancer cell line A549 & $\begin{array}{l}\text { UV-Vis. spectroscopy, FTIR, } \\
\text { XRD, TEM, EDX, AFM }\end{array}$ & $\begin{array}{l}\text { Spherical, triangular, } \\
\text { hexagonal }\end{array}$ & $6-29 \mathrm{~nm}$ & [184] \\
\hline
\end{tabular}




\section{Anticancer Mechanism of Green Synthesized Gold Nanoparticles}

There are many anticancer mechanisms of green synthesized nanoparticles that have been reported. However, three proposed mechanisms are well accepted (Figure 4). Firstly, the interaction of NPs with cell membranes interferes with cell permeability and causes mitochondrial dysfunction $[185,186]$. Secondly, the ROS-induced apoptotic pathway involves an elevated level of ROS and results in oxidative stress and the fragmentation of DNA in the cancerous cell [187]. Thirdly, it can cause interference with the chemistry of proteins/DNA. AuNPs has been reported to be a novel anticancer agent in cancer therapy. It shows sizedependent cytotoxic activity against different cancer cells $[188,189]$. The use of AuNP in cancer therapy shows minimum side effects and cytotoxic effects to normal (noncancerous) cells [167]. The anticancer mechanism of AuNP is provisionally described in many reports. According to some reports, AuNPs interact with cells in numerous ways; many researchers have reported the cellular internalization of AuNPs [190,191]. The surface properties of AuNPs act as essential factors in cellular internalization. The mechanism behind AuNPs uptake and internalization by cells is due to opposite charges between AuNPs and cell membrane. AuNPs carry positive charges, while cancer/normal cell membranes contain lipids (especially phosphate groups) which carry a negative charge (especially phosphate groups) $[190,191]$. Additionally, some reports suggested that gold nanoparticles enter into cells through endocytosis. Researchers have reported that the endocytosis of tiny AuNPs and showed aggregation inside HeLa cells [189]. After gaining entry into the mitochondria, they involve different pathways, including impairment of the electron transport chain, structural damage, activation of NADPH enzymes, and the depolarization of mitochondrial membranes [192,193]. AuNPs have been reported to show cytotoxic activity through ROS production [194]. AuNPs cause elevated levels of intracellular ROS in cancerous cells. It was suggested that ROS production is an essential factor in the molecular mechanisms behind the anticancer effect of AuNPs. Excessive ROS production results in irreversible oxidative damage, DNA destruction, and cell death via apoptosis, autophagy, or necroptosis pathways [195]. Apoptosis and autophagy, programmed cell death (PCD) processes, are the major cellular, molecular mechanisms regulating cancer development and progression. Thus, they can be used as important targets for anticancer mechanisms [196]. Increased levels of ROS that are higher than the beneficial physiological concentration causes elevated NADPH level. This can lead to disruption of oxidative balance and impairment of anti-oxidative molecules, resulting in oxidative stress and mitochondrial dysfunction in cancerous cells. Excessive oxidative stress leads to apoptotic cell death. AuNP also causes mitochondrial dysfunction and caspase-dependent apoptosis [194]. Elevated ROS generation also causes depletion of intracellular glutathione. The decline in cellular glutathione concentration and dysregulation of the mitochondrial transmembrane potential are important events occurring early in apoptosis. Mitochondria are the prominent target getting damaged during ROS-induced apoptosis [197]. Due to oxidative stress and membrane permeabilization, mitochondria release some death molecules, such as cytochrome-c, Apoptosis-inducing factor (AIF), Endonuclease G (ENDO-G), etc., from mitochondria to cytosol and nucleus $[198,199]$. This death molecule causes the final execution of cell death. Caspase-dependent apoptosis is also another leading anticancer mechanism of AuNPs. Caspase zymogens play a crucial role in a biochemical event during apoptosis. The JNK signalling pathway has been reported to be involved in AuNPs-mediated caspase activation and apoptosis process. C-Jun N-terminal kinase (JNK) is an important member of the mitogen-activated protein kinase superfamily, the pathway of which is activated due to elevated levels of ROS [200,201]. Death molecule cytochrome-c release from mitochondria form an apoptosome complex in the cytosol, which results in the activation of initiator caspase-9 [202]. Activated initiator caspases further cleave and activate executioner caspases, such as casp-3, 9, and 7, which can cause cell death. However, mitochondria also release AIF and Endo-G in the cell nucleus, which causes caspase-independent apoptosis $[198,203]$. Scholars have reported the activation of casp-3 protein in NPs exposed to 
MDA-MB-231, HeLa, and HCT116 cancer cells, whereas it was absent in untreated cancer cells [204]. They also reported the cleavage of PARP (Poly ADP-ribose polymerase) in the cells exposed with NPs, which is a major downstream substrate for activated casp-3 protease in cancer cells [205]. AuNPs are also found to be responsible for ER stress by activating stress-related proteins, also called ER sensors, IRE1 (inositol-requiring protein-1), ATF-6 (activating transcription factor-6) and PERK (protein kinase RNA (PKR)-like ER kinase in the endoplasmic reticulum. It is reported that AuNP activates caspase 4, which is normally associated with ER stress, resulting in caspase-mediated apoptosis [206]. Researchers have reported that AuNPs induce the elevated expression of the apoptotic gene bid, bax/bcl2 in HCT-116 cells [207]. These lead to cell cycle arrest in the G0/G1 phase and, ultimately, apoptosis. AuNPs has been reported to interfere with and decrease the metabolic activity of cancer cells. They have also been shown to decrease DNA biosynthesis by directly binding to DNA [160] and inhibit DNA repair-related proteins' expression. According to some reports, AuNP interacts with intracellular components of the NF- $\mathrm{kB}$ signalling pathway. NF-B is a key regulator of programmed cell death and is associated with cancer progression by the transcriptional regulation of responsive genes. NF- $\mathrm{kB}$ signal transduction proteins IKB kinases (IKK) have cysteine residues and thiol groups, which is the binding substrate of Au-NPs [208,209]. After binding, AuNPs induced apoptosis with dose-dependent decreases in NF-B transcriptional activities.

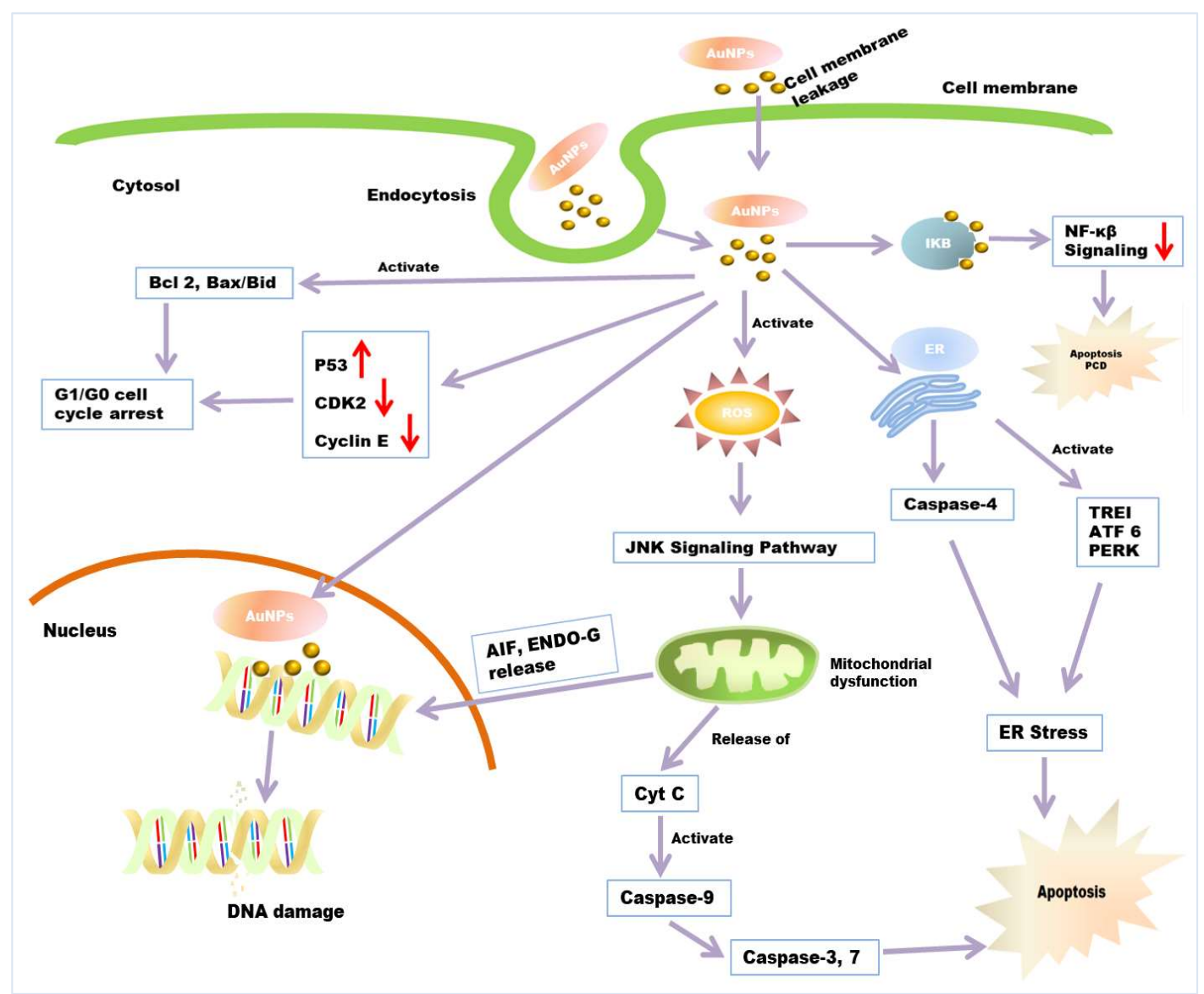

Figure 4. Anticancer mechanism of AuNPs. Entry of AuNPs into the cell's endocytosis or cellular internalization through a lipid bilayer. AuNPs induce the apoptosis of cancerous cells through ROS-mediated mitochondrial dysfunction and caspase activation. AuNPs causes ER stress through the activation of caspase 4 and stress-related proteins, which also results in apoptosis. Damaged mitochondria release AIF, ENDO-G into the nucleus, which causes the final execution of cell death. AuNPs increases the expression of P53 and decreases the expression of CDK2, Cyclin E. It also elevates the expression of apoptotic gene bid, bax/bcl2, which ultimately leads to G0/G1 phase cell-cycle arrest. AuNP induces PCD and apoptosis through the interfering NF- $\mathrm{BB}$ signalling pathway. 


\subsection{Applications and Limitations of AuNPs in Drug Delivery for Cancer Therapy}

Drug delivery systems are engineered technologies designed for the targeted, efficient delivery of therapeutic agents in a controlled manner. Biomedical engineering contributed to our understanding of the physiological barrier for the drug. This constitutes a step in the right direction in cancer treatment, where the drug has to reach the required location in the desired concentration and remain there for a sufficient period. Most conventional approaches targeting the cancer cells lack adequate contact time, are less stable, lack specificity, and are susceptible to biochemical degradation. Thus, the drug delivery system, based on nanotechnology, is an answer to effective, targeted drug therapy for cancer diagnostics and therapy. A variety of nanotechnological approaches, such as nanoparticles [210], nanoemulsion [211], liposomes [212], niosomes [213], cubosomes [214], spanlastics [215], nanomicelles [216], and nanostructured lipid-carriers (NLC) [217] were used for the drug delivery system used. However, green synthesized metal nanoparticles are an effective strategy and a topic of pivotal importance in the application of drug delivery in therapeutic anticancer research. In recent years, this topic constitutes a new domain with largely unstudied potential. In general, metal nanoparticles, particularly AuNPs, have been observed to be used in various applications, such as drug delivery, molecular imaging and cancer diagnostics and therapy, which depend on the exploitation of important sources, mainly microbes, plants and fruit waste [218]. With advances in the development of nanotechnology-mediated drug delivery systems, plant extracts derived from AuNPs are often selected as having a potential advantage in cancer therapy compared to conventional methods. This has significant advantages in toxicity, eco-friendliness, simplicity and safety, but is not limited to these [79,219]. In addition, the multifunctionality of AuNPs has garnered worldwide attention in the past decade due to the desired particle size, high surface-to-volume ratio, ease of synthesis and high drug loading capacity, making them particularly attractive candidates for drug delivery in cancer therapy. There have been a number of studies that have investigated AuNPs as a promising agent for delivering drugs to tumour sites as either active or passive targeting. There is a growing area of research that uses nanotechnology approaches to prevent ocular cancer. A good overview of earlier work in this area is provided by scholars who suggest that AuNPs significantly suppress VEGF-induced angiogenesis for the retinal neovascularization of endothelial cells and the autophosphorylation to suppress VEGF-2 for the regulation of protein kinases [220]. In one study, it was observed that AuNPs were directly conjugated with the methotrexate and act as a potent anti-cancer agent by disrupting the folate metabolism in the malignant lung cancer cell. Furthermore, the insight into the cancer cell shows that conjugated methotrexate has a higher accumulation in the cell compared to methotrexate alone [221]. This concept has led to a further improvement in cancer diagnostics, with Bhattacharya and colleagues finding that cancer cells that express the folate receptors become more susceptible to targeting AuNPs conjugated with folic acid and PEG-amines [222]. One of the interesting properties of AuNPs is the 'plasmon resonance', which is demonstrated in the presence of light (UV and visible) and used to release drugs at the target site, which has been widely emphasized in the literature for disease management. Light-mediated drug delivery is one of the most powerful strategies for in vitro and in vivo analysis in cancer diagnostics. Some time ago, the authors of $[223,224]$ pointed out that the photothermal ablation and photodynamic therapy of AuNPs were also tested for the targeted drug delivery into cancer cells. One particularly notable study describing this fact can be seen in the results of Agasti and co-workers. They showed that illumination with light causes the discharge of the therapeutic anticancer drug 5-fluorouracil from the nanoconjugates of the AuNPs at the target site. These properties can aid in making the drug delivery system more efficient, as more drugs can be efficiently delivered in the light-mediated process compared to the absence of light [225]. Similarly, researchers suggested that DNA-wrapped AuNPs loaded with DOX (GNR@DOX) should be used to treat metastatic breast cancer through chemotherapy and photothermal ablation [226]. Several notable attempts have been made to improve targeted drug delivery, solubility, performance and regulated drug 
release at specific sites using AuNPs as drug carriers. The $\mathrm{pH}$-mediated drug transport at the respective site is the most appropriate approach, which involves the cleavage of the bond, thus releasing the drug from the metal nanocarrier in an acidic environment, followed by morphological changes in the carrier nanostructure. It has been stated that, stimuli-responsive drug carriers based on AuNPs would be an ideal method of choice, since a lower $\mathrm{pH}$ value near the cancer site is effectively exploited for the controlled release of therapeutic drugs from nanoconjugates of AuNPs [227,228]. In this regard, Joshi and group are trying to explore whether or not the chloroquine-AuNPs conjugates have an anticancer effect in breast cancer cell lines. They also found that an acidic $\mathrm{pH}$ condition near human breast cancer or within the cell provides appropriate conditions for chloroquine to be released from the conjugates. The cytotoxicity of this chloroquine-AuNPs conjugates was quantitatively estimated at different concentrations in MCF-7, which led to an $\mathrm{IC}_{50}$ value of $30 \pm 5 \mathrm{~g} / \mathrm{mL}$. This result demonstrates a better performance of the conjugates in the delivery of chloroquine as well as an improved anti-cancer potential through activation of cell-death mediated by autophagy [229].

In a remarkable study, a new and promising approach using microRNA (miRNA) led to cancer therapy development. In this approach, the authors discussed the miRNAs functionalized nanoconjugates of AuNPs, targeting intracellular proteins by interacting with their transcribed RNA. They inhibited cancer cell viability by minimizing the protein expression by using the targeted miRNA-miR-205 conjugated to AuNPs compared to non-targeted AuNPs [230]. The use of green synthesized AuNPs has recently been of great importance due to their fabrication, monodispersity, ease of synthesis, low toxicity, eco-friendly and useful tools for drug delivery. AuNPs captured more attention due to their excellent properties, such as antibacterial, antifungal, anti-inflammatory and anticancer properties, which could pave the way for the development of potential therapeutics. However, there is still a great deal of work to be done in this area.

\subsection{Gold Nanoparticles in Cancer Cell Diagnosis}

Gold nanoparticles (AuNPs) have attracted a lot of interest in cancer detection and diagnostics because of their intrinsic properties [231]. AuNPs have lower systemic cytotoxicity, are extremely stable, and are nonimmunogenic in vivo. Various targeting strategies, viz., passive targeting or active targeting, can be used to increase the effectiveness of a drug as AuNPs accumulate preferentially in tumours can improve imaging sensitivity [232]. AuNPs have been considered a possible tool for cancer diagnostics and drug delivery due to their unique features. These characteristic features include a high surface area to volume ratio, surface plasmon resonance (SPR), multi-functionalization, easy synthesis, and stable nature. Furthermore, gold nanoparticles' non-toxic and non-immunogenic nature and their high permeability and retention provide better penetration and accumulation at tumour locations [233]. Gold nanoparticles are being used in a variety of novel ways in cancer diagnostics (Figure 5). Gold nanoparticles with unique properties such as smaller size, biocompatibility, and higher atomic number exhibit the potential to conjugate with targeting agents display the potentiality as contrast agents. The mass attenuation of gold at energies $>80 \mathrm{kV}$ was revealed to be more than that of iodine, which also signifies a better contrast agent for imaging [234]. The gold nanoparticles conjugated with several biologically active components, such as amine and thiol groups, may aid biomedical applications, including diagnostics, targeted delivery, imaging, and sensing for electron microscopy markers [235]. Upon binding AuNPs with moieties, the physicochemical properties, such as conductivity, redox behaviour, and SPR, are altered and generate signals that enable the potential of AuNPs as diagnostic agents [236]. 


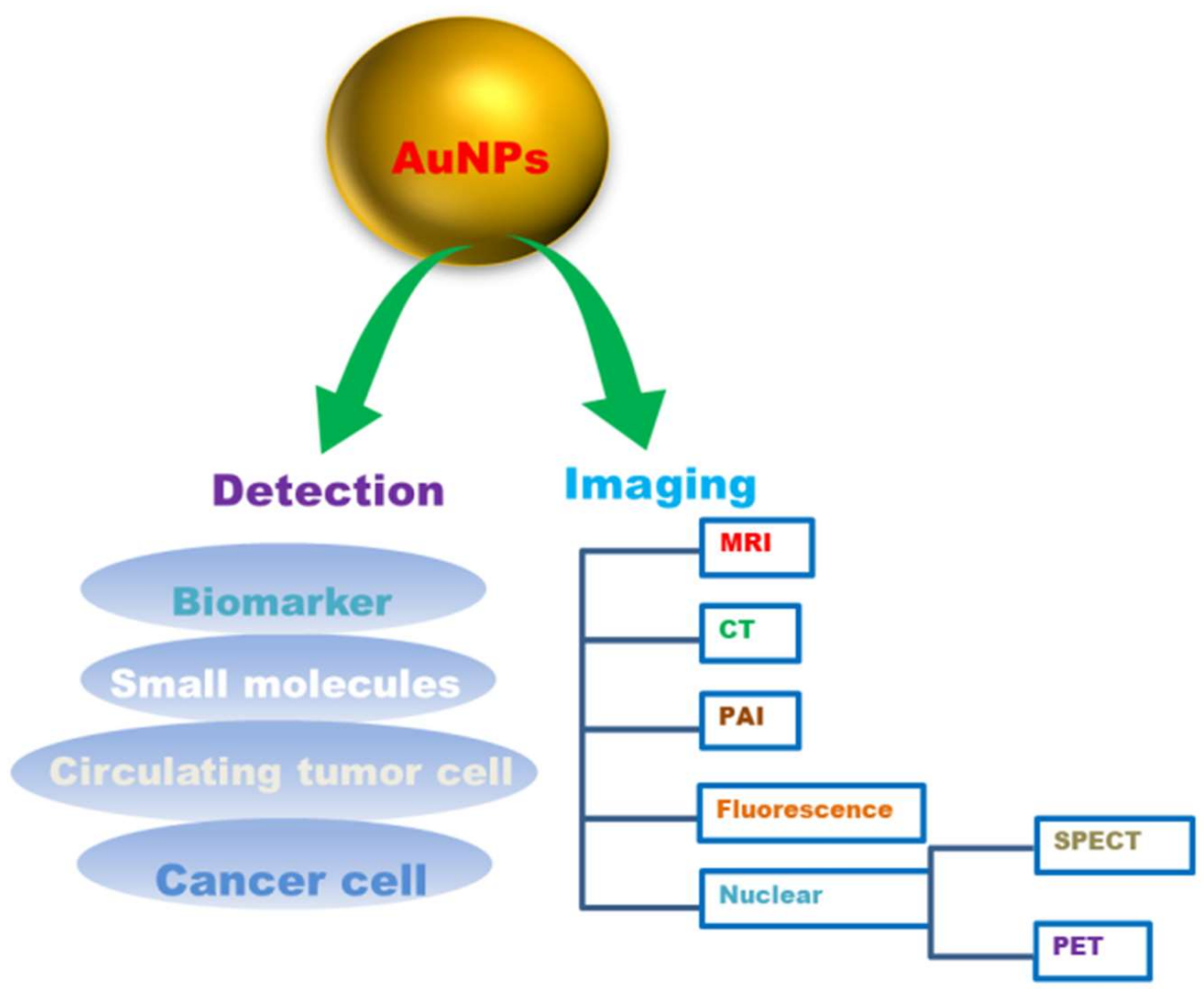

Figure 5. Gold nanoparticles (AuNPs) in cancer diagnosis.

AuNPs are being utilized as promising tools for real-time, convenient, and costeffective cancer diagnosis and detection [237]. The main constraint of various in vitro diagnostic systems is their average detection sensitivity. For example, prostate cancer biomarker detection with enzyme-linked immunosorbent assay (ELISA) can detect a threshold limit of about $0.1 \mathrm{ng} / \mathrm{mL}$, which is normally higher than the concentrations of a cancer biomarker in most serum samples. AuNPs, tend to have high sensitivity for the detection of biomarkers [238]. Their unique physical and optical properties, viz., localized surface plasmon resonance (LSPR), fluorescence resonance energy transfer (FRET), surface-enhanced Raman scattering (SERS), nonlinear optical properties, and quantized charging effect. Enhance AuNPs to sense or detect various targets [238]. AuNPs can help in vitro detection of biomolecules and be used as a diagnostic agent for cancer diagnosis by conjugation with biomarkers viz., oligonucleotides or antibodies to detect the target components [236]. It was reported that it was possible to identify and track the primary glioma cells using mercaptoundecanoic acid-coated AuNPs in mouse brains [239]. Gold nanoparticles (AuNPs) were also reported to be capable of diagnosing with CTC detection. It has been demonstrated that AuNPs can boost the sensitivity and the specificity of CTC detection appliances, and have the ability to aid in cancer diagnosis as well as prognosis [3]. Various imaging technologies, such as computed tomography, ultrasound and magnetic resonance, can provide precise information about disease diagnosis and therapy. AuNPs with unique tuneable chemical and physical properties could thus be an ideal contrast agent for imaging. The use of gold nanoparticles as contrast agents for imaging diagnosis is suitable for various imaging techniques ranging from magnetic resonance imaging (MRI), computed tomography (CT), nuclear imaging, fluorescence imaging, photoacoustic imaging (PAI) to various other imaging techniques (Table 4). 
Table 4. Gold nanostructures used in imaging-based diagnostics.

\begin{tabular}{cccc}
\hline Nanostructure & Tumour Model/Cell Line & Imaging Modality & References \\
\hline AuNPs & Prostate tumour (PC3) & MRI & {$[240]$} \\
\hline AuNPs & Prostate tumour (PC3) & CT & {$[241]$} \\
\hline$[198 \mathrm{Au}]$ AuNCs & - & SPECT & {$[242]$} \\
\hline 64CuAuNCs & Breast tumour (4T1) & PET & {$[243,244]$} \\
\hline AuNCs & $\begin{array}{c}\text { Breast tumour } \\
\text { (MDA-MB-231) }\end{array}$ & Fluorescence & {$[245]$} \\
\hline AuNPs & A431 cells & PAI & {$[246]$} \\
\hline AuNPs & - & CT & {$[247]$} \\
\hline $\begin{array}{c}\text { Au/Ag hybrid } \\
\text { nanoparticles }\end{array}$ & SKOV3 & PA & {$[248]$} \\
\hline AuNU-pHLIP & MCF-7 & CT/PA & {$[249]$} \\
\hline AuNR-SiO - PFP & A375 & US/PA & {$[250]$} \\
\hline $\begin{array}{c}\text { DT-AuNR/PDA bowl } \\
\text { spadix-bract NP }\end{array}$ & Hep-G2, HeLa, MCF-7 & CT/PA & {$[251]$} \\
\hline BL-Au NPs & Zebrafish model & CT & {$[252]$} \\
\hline
\end{tabular}

\section{Phyto-Based Gold Nanoparticles (AuNPs) in Cancer Imaging}

Plant extract-synthesized gold nanoparticles have emerged as a promising option for biosensors, immunoassays, and imaging. Interestingly, several types of gold nanoparticles, such as gold nanorods, nanocages, nanostars, nanocubes, and nanospheres, have proven to be efficient tools in cancer research. Their excellent optical and physical properties aided in cancer diagnostics and treatment. Some of the examples using imaging modalities in cancer diagnosis are briefly discussed.

\subsection{Magnetic Resonance Imaging (MRI)}

Magnetic resonance imaging (MRI) is one of the non-invasive diagnostic modalities widely used in the clinic for disease diagnosis, imaging and cell tracking. MRI follows the principle of nuclear spin, i.e., nuclear magnetic resonance (NMR) and proton spin relaxation that aligns parallel or antiparallel to an applied magnetic field [232,253]. Superparamagnetic iron oxide nanoparticles (SPION) were extensively used in MRI as contrast agents, but due to the remarkable toxicity caused by SPION in vivo with ROS generated toxicity, cellular damage (DNA, protein) and inflammation ensued [253,254]. Therefore, SPION is no longer used in MRI clinical applications [255]. Interestingly, AuNPs have no toxic effect and have been extensively utilized for in vivo applications [253]. For instance, grape seed synthesized magnetite-gold nanohybrids $\left.\left(\mathrm{Fe}\left({ }_{3}\right) \mathrm{O}_{4}\right) / \mathrm{Au}\right)$, used as contrast agents, were found to be suitable for MRI and CT imaging. The magnetite enables superparamagnetism in MRI, and the gold nanoparticle in the hybrid provides X-ray contrast in CT imaging. The nanohybrids were biocompatible and used for labelling and imaging stem cells [256].

\subsection{Computed Tomography (CT)}

Computed tomography (CT) is one of the most widely employed imaging modalities in clinics based on X-rays. CT is a non-invasive imaging tool that can visualize threedimensional anatomical images for cancer diagnosis and therapy. AuNPs are recognized as potential CT contrast agents due to their high atomic number and density, which exhibit a high intrinsic X-ray absorption coefficient [257]. Previous studies reported that iodine-based contrast agents showed faster renal clearance and renal toxicity than AuNPs. AuNPs showed 2.7 times more $\mathrm{X}$-ray mass attenuation than iodine, which attracts more attention towards enhancing CT imaging $[232,258]$. Studies reported that plants that originated from Hubertia ambavilla and Hypericum lanceolatum, based on shell-like hybrid 
flavonoid-gold nanoparticles (NPs) hybrid complexes (of about $15 \mathrm{~nm}$, or flower-shaped $40 \mathrm{~nm}$ diameter), were developed for a double nanotheranostic activity. This double nanotheranostics implies plasmonic phototherapeutic for cancer therapy by plasmonic phototherapy and X-ray-based computed tomography for visualization by computed tomography [247]. In another study, barley leaf-mediated gold nanoparticles (BL-AuNPs) were synthesized and visualized by CT images in vitro and showed that the BL-AuNPs have better X-ray attenuation ability than the commonly utilized iodinated contrast agent. The study also revealed that BL-AuNPs are a good contrast agent for successful CT imaging of the zebrafish model. These results demonstrated the effective use of BL-AuNPs as a CT imaging contrast agent for disease diagnosis [252].

\subsection{Fluorescence Imaging}

Fluorescence-based optical imaging has great potential for studying biological events at the molecular level and early-stage cancer diagnosis [259]. Fluorescence imaging relies on a linear relationship between the intensities of fluorescent signals emitted by the excitation of fluorescent components and the amount of fluorescent material at a certain range [253]. In a study, Olax scandens leaf extract synthesized fluorescently labelled AuNPs (AuNPs-OX) were added to lung (A549), breast (MCF-7) and colon (COLO 205) cancer cells and were found to be helpful for the detection of the cancer cells. AuNPs-OX displayed strong red fluorescence in cancer cells compared to aqueous leaf extract alone [260].

\subsection{Photoacoustic Imaging}

Photoacoustic imaging (PAI) is a real-time biomedical imaging modality with noninvasive properties, which provides functional details about tissues' cellular structure and molecular events, by applying endogenous and exogenous contrast agents [261]. The PAI technique relies on energy conversion from light to sound [262]. Imaging agents with high photothermal conversion potential are a prerequisite for better photoacoustic contrast [263]. Gold nanoparticles as contrast agents have tremendous potential for PAI due to their intrinsic and geometrically induced optical properties. For example, Cinnamonsynthesized AuNPs provided a suitable diagnostic agent for in vitro and in vivo imaging. These AuNPs are biocompatible and pure, so can be utilized for in vivo applications. The uptake Cinnamon-AuNPs were visualized in PC-3 and MCF-7 cells in vitro and detected by photoacoustic signals. Moreover, biodistribution studies in normal mice showed that these AuNPs accumulated in the lungs, which further indicated the use of AuNPs as contrast agents for targeting [264].

\subsection{Application of AuNPs in Magnetic Particle Imaging (MPI)}

The concept of magnetic particle imaging (MPI) was introduced by researchers, and relies on the non-linearity of the magnetization curves of ferromagnetic materials. With this discovery, it becomes possible to obtain high-resolution images of magnetic tracers used for diagnosis. They have also demonstrated the feasibility of the imaging method through the achievement of the image with resolution below $1 \mathrm{~mm}$ [265]. MPI, as a tracer-based tomographic imaging modality, can determine the spatial distribution of magnetic nanoparticles (MNPs) and has applications in vast biomedical arenas, such as cell targeting, drug delivery, and diagnostic imaging, as well as in magnetic hyperthermia [266]. Nowadays, magnetic particle spectroscopy (MPS) or magnetisation response spectroscopy (MRS) is evolving as a versatile measurement tool derived from MPI. This is basically designed to characterised superparamagnetic iron oxide nanoparticles (SPIONs) regarding their applicability in MPI [267]. Most of the recent works have focused on the application of iron-oxide-based magnetic nanoparticles (MNPs) in MPI. However, AuNPs in combination with MNPs also find their applicability in MPIs due to their various physicochemical properties. A nanoparticle possessing both plasmonic as well as magnetic properties within the same nanosystem has efficient application in magnetic particle imaging, along with other image-guided therapy. The core shell-shaped gold nanoparticles coated with 
polyethylene glycol, having a magnetic cum plasmonic effect MNPs@Au, was synthesised by the reduction of $\mathrm{HAuCl}_{4}$ having a potential application in MPI [268]. The star-shaped plasmonic shell of gold nanobranches with high aspect ratio, with a superparamagnetic iron core offering a unique nanostar structure that is useful for the application in MPI, is proposed by a group of researchers. It was found that the model drug molecules can bind to the core-shell Nanostars and were released when illuminated with near infrared (NIR) due to heat release from the core shell Nanostars [269].

\section{Immunomodulatory Properties of AuNPs}

Gold nanoparticles (AuNPs) have been shown to have several immunomodulatory properties. Dendritic Cells have been considered an important model to investigate potential immunomodulatory properties of NPs [270]. According to some reports, in the absence of pro-inflammatory stimuli (IL-1 $\beta$, TNF- $\alpha$ ), AuNPs do not have any immunomodulatory properties and can be considered immunologically safe. However, under pro-inflammatory conditions, $26 \mathrm{~nm}$ AuNPs may show immunomodulatory capacities [271]. AuNPs also inhibit dendritic cell (DC) activation, reduced expression of activation marker CD86, decrease in the secretion of pro-inflammatory cytokines IL-12 and IL-27, and concomitant upregulation of the anti-inflammatory receptor ILT3, which ultimately results in anti-inflammatory responses. Moreover, several reports suggested other different anti-inflammatory responses of AuNPs $[137,272]$. Pro-inflammatory cytokines IL- $1 \beta$, TNF- $\alpha$ and IFN- $\gamma$, produced by innate immune component macrophages and natural killer (NK) cells, were generally released in response to bacterial and tissue infections. However, prolonged inflammation can contribute to the etiology of several diseases, such as rheumatoid arthritis, inflammatory bowel disease, multiple sclerosis, psoriasis, and eczema [273]. The expressions of these cytokines, including IL- $1 \beta$, IL- 6 and TNF- $\alpha$, were altered in rats and animals after being injected with AuNPs [274]. Citrate-stabilized AuNPs downregulate the cellular response induced by IL-1 $\beta$ both in vivo and in vitro, resulting in anti-inflammatory responses. It has been signified that the increased production of reactive oxygen species (ROS) in response to AuNPs also involves anti-inflammatory actions [275]. Some studies have suggested that (Mangiferin) MGF-AuNPs effectively target tumour-associated macrophages (TAMs), which show immunomodulatory properties by infiltrating most solid tumours. Macrophages have pro-tumour or anti-tumour phenotypes. Classically activated macrophages (referred to as M1), and alternatively activated macrophages (referred to as M2), fit two extremes within the spectrum of the macrophage phenotypes [276]. M1 macrophages are involved in pathogens phagocytosis and the activation of antitumor activity by IL-12-dependent natural killer (NK) cell recruitment. However, tumour-associated macrophages (TAM) exhibit the expression of the M2-like phenotype along with high IL-10, high arginase-1 and low IL-12 expression, which is involved in pro-tumorigenic activities and ultimately contributes to drug resistance to several diseases. MGF-AuNPs initiate macrophage re-education from pro-tumour M2 macrophages to the antitumor M1 phenotype, resulting in tumour growth restriction and metastasis by eliminating cancer cells $[277,278]$.

\section{Limitations of Using AuNPs in Biomedical Applications}

Toxicity is considered a major concern regarding the limitations of using AuNPs in biomedical applications. Different properties of AuNPs, including shape, size, surface chemistry, targeting ligand, elasticity, and composition, influence their toxicity to biological systems [279]. Previous research investigations have shown that chemically synthesized AuNPs that are smaller than $20 \mathrm{~nm}$ are highly toxic to stem cells, affecting cellular DNA methylation and hydromethylation patterns, whereas green synthesized AuNPs have been proven to be an effective anticancer drug carrier, delivering drugs to cancer cells and killing them. The toxicity of AuNPs is thus dependent on the synthesis method, which determines their size, morphology, topology, and surface functional group [280]. Moreover, in combination with the complexity and heterogeneity among human cells and tissues, it 
is challenging to comprehensively probe the effect and response of the biological system to the administration of AuNPs. In a study conducted by Khan and colleagues, mice were given different types of dendrimers-encapsulated AuNPs (5-22 nm) with positive, negative, or neutral surface charges. The gold content of the various organs, blood, and excrements was determined after the sacrifice. The researchers came to the conclusion that nanoparticle size and surface charge affect biodistribution. The smallest positive particles concentrating in the kidneys and the bigger ones accumulating in the spleen, liver, lungs, and heart. Even though AuNPs are said to be non-toxic by nature, it is crucial to distinguish between the toxicity of the nanoparticles and the toxicity of the capping ligands. Certain capping ligands may be more toxic than others [281]. Additionally, there is currently no significant standardized assay available that could be applied to test the AuNPs toxicity effect. The lack of standardized assays results in varying interpretations or assumptions. This is also a significant limitation of nanoparticles administration. It is important to emphasize that AuNPs are biodegradable. The NPs might take longer to excrete and they may accumulate in the liver and spleen. The bioaccumulated AuNPs may interfere with different diagnostic techniques, or accumulated AuNPs will exhibit catalytic properties [282]. Therefore, the biodistribution and excretion factors must be studied comprehensively in various animal models with appropriate sample sizes and robust statistical studies. In combination with potential toxicity, all of these concerns are immense limitations of AuNPs on various successful clinical applications. More research is needed on this domain to overcome these limitations. Elimination of accumulating NPs from cancer patients is challenging. No significant technology is currently available to date. However, Shahidi Bonjar described a "Nanogold detoxifying machine" to filter idle AuNPs from the blood of treated cancer patients [283]. The equipment, which resembles a "hemodialysis machine", might improve the safety of AuNPs therapy for specific tumours and prevent AuNP accumulation in non-target tissues or organs following treatment.

\section{Future Prospect and Conclusions}

In the 21st century, the biogenesis of nanomedicine has a great deal of potential for treating cancer by developing efficient anticancer nanomedicine and drug delivery systems that deliver potent drugs effectively to specific targeted areas. Looking at the enormous significance of AuNPs over the past few years, and the safety and biocompatibility of green synthesis methods, it is envisaged that green synthesized AuNPs will eventually be beneficial in cancer therapy and diagnostic area. Plant-based AuNPs are likely to be highly advantageous in the fight against cancer due to their biocompatibility and pronounced anticancer therapeutic and diagnostic efficacy. These AuNPs may pave the way for developing a new generation of anticancer medicines in this fashion. Because of its pharmaceutical applications, the AuNPs industry has already evolved into a massive economy and is expected to increase more worldwide. If significant innovations and research is performed, plant-based AuNPs will provide a considerable portion of this percentage. Plant-based synthesis can provide a convenient and cost-effective outlet for AuNPs. Extensive research should be focused on designing and engineering the synthesis of plant-based AuNPs to meet the expectations commonly placed on chemically synthesized AuNPs. The green synthesis of AuNPs is still in its early stages. However, the in vivo study of AuNPs in various animals, along with three-dimensional spheroids and organoids models, has received little attention in the published literature. More research on this is needed, which will boost confidence in translational to clinical studies for the effective and safe utilization of AuNPs in cancer patients. The mass-scale manufacture of cost-effective and efficient AuNPs functionalized with moieties such as anticancer drugs and targeting ligands are required to achieve this.

Thus, certain efforts were needed to enhance nanoparticles synthesis at a large scale, successful clinical trial, resulting in nanoparticles with potential therapeutic applications, such as personalized cancer therapy. 
Author Contributions: Conceptualization, D.B. (Debabrat Baishya), K.K.B., N.H.M.N. and B.R.; methodology, K.K.B., B.R., T.S. and S.P.; formal analysis, K.K.B., B.R., T.S., B.K.C., D.B. (Debabrat Baishya), A.B., A.S.; investigation S.P., T.S. and K.K.B.; writing-original draft prepa-ration, K.K.B., B.R., T.S., S.P., N.H.M.N., B.K.C., D.B. (Dorothy Bhattacharjya), A.B., A.S., Z.A.K., H.A.E.; writingreview and editing, K.K.B., B.R., T.S., S.P., B.K.C., D.B. (Dorothy Bhattacharjya), A.B., A.S., Z.A.K., N.H.M.N. and H.A.E. All authors have read and agreed to the published version of the manuscript.

Funding: No funding has been received from any funding agency to carry out the work. The financial support associated with publication of this work was supported by Universiti Sains Malaysia.

Conflicts of Interest: The authors declare no conflict of interest.

\begin{abstract}
Abbreviations
AFM-Atomic force microscopy, CV-Cyclic voltammetry, DLS-Dynamic Light Scattering, DPV— Differential pulse voltammetry, EDS/EDX—Energy Dispersive X-ray Spectroscopy, EMA—European Medicines Agency, FDA—Food and Drug Administration, FTIR-Fourier transform infrared spectroscopy, GCMS - Gas Chromatography-Mass Spectrometry, HPLC - High-performance liquid chromatography, HRTEM-High-Resolution Transmission Electron Microscopy, ICPAES-Inductively Coupled Plasma Atomic Emission Spectroscopy, PSA-Particle Size Analysis, SPR-Surface Plasmon Resonance, SAED—Selected Area Diffraction, TGA-Thermogravimetric Analysis or Thermal Gravimetric Analysis, NTA-Nanoparticle Tracking Analysis, SAED—Selected area electron diffraction, XRD-X-ray diffraction, XPS-X-ray Photoelectron Spectroscopy, NMR-Nuclear Magnetic Resonance, SEM-Scanning Electron Microscopy, SPR—Surface Plasmon resonance, TEM-Transmission Electron Microscopy, ZP-Zeta Potential.
\end{abstract}

\title{
References
}

1. Amina, S.J.; Guo, B. A Review on the Synthesis and Functionalization of Gold Nanoparticles as a Drug Delivery Vehicle. Int. J. Nanomed. 2020, 15, 9823-9857. [CrossRef]

2. Nirmal, N.P.; Mereddy, R.; Li, L.; Sultanbawa, Y. Formulation, characterisation and antibacterial activity of lemon myrtle and anise myrtle essential oil in water nanoemulsion. Food Chem. 2018, 254, 1-7. [CrossRef]

3. Zhang, Y.; Li, M.; Gao, X.; Chen, Y.; Liu, T. Nanotechnology in cancer diagnosis: Progress, challenges and opportunities. J. Hematol. Oncol. 2019, 12, 137. [CrossRef]

4. Sevieri, M.; Silva, F.; Bonizzi, A.; Sitia, L.; Truffi, M.; Mazzucchelli, S.; Corsi, F. Indocyanine Green Nanoparticles: Are They Compelling for Cancer Treatment? Front. Chem. 2020, 8, 535. [CrossRef] [PubMed]

5. Signati, L.; Allevi, R.; Piccotti, F.; Albasini, S.; Villani, L.; Sevieri, M.; Bonizzi, A.; Corsi, F.; Mazzucchelli, S. Ultrastructural analysis of breast cancer patient-derived organoids. Cancer Cell Int. 2021, 21, 423. [CrossRef] [PubMed]

6. Ahmad, M.; Nirmal, N.P.; Danish, M.; Chuprom, J.; Jafarzedeh, S. Characterisation of composite films fabricated from collagen/chitosan and collagen/soy protein isolate for food packaging applications. RSC Adv. 2016, 6, 82191-82204. [CrossRef]

7. Rabha, B.; Bharadwaj, K.K.; Baishya, D.; Sarkar, T.; Edinur, H.A.; Pati, S. Synthesis and Characterization of Diosgenin Encapsulated Poly- $\varepsilon$-Caprolactone-Pluronic Nanoparticles and Its Effect on Brain Cancer Cells. Polymers 2021, 13, 1322. [CrossRef] [PubMed]

8. Bharadwaj, K.K.; Rabha, B.; Pati, S.; Choudhury, B.K.; Sarkar, T.; Gogoi, S.K.; Kakati, N.; Baishya, D.; Kari, Z.A.; Edinur, H.A. Green Synthesis of Silver Nanoparticles Using Diospyros malabarica Fruit Extract and Assessments of Their Antimicrobial, Anticancer and Catalytic Reduction of 4-Nitrophenol (4-NP). Nanomaterials 2021, 11, 1999. [CrossRef]

9. Son, K.H.; Hong, J.H.; Lee, J.W. Carbon nanotubes as cancer therapeutic carriers and mediators. Int. J. Nanomed. 2016, 11, 5163-5185. [CrossRef]

10. Neerooa, B.N.; Ooi, L.-T.; Shameli, K.; Dahlan, N.A.; Islam, J.M.M.; Pushpamalar, J.; Teow, S.-Y. Development of Polymer-Assisted Nanoparticles and Nanogels for Cancer Therapy: An Update. Gels 2021, 7, 60. [CrossRef]

11. Alphandéry, E. Natural Metallic Nanoparticles for Application in Nano-Oncology. Int. J. Mol. Sci. 2020, 21, 4412. [CrossRef]

12. Rommasi, F.; Esfandiari, N. Liposomal Nanomedicine: Applications for Drug Delivery in Cancer Therapy. Nanoscale Res. Lett. 2021, 16, 95. [CrossRef] [PubMed]

13. Farzin, A.; Etesami, S.A.; Quint, J.; Memic, A.; Tamayol, A. Magnetic Nanoparticles in Cancer Therapy and Diagnosis. Adv. Healthc. Mater. 2020, 9, 1901058. [CrossRef] [PubMed]

14. Nirmal, N.P.; Santivarangkna, C.; Rajput, M.S.; Benjakul, S. Trends in shrimp processing waste utilization: An industrial prospective. Trends Food Sci. Technol. 2020, 103, 20-35. [CrossRef]

15. Lahiri, D.; Nag, M.; Sheikh, H.I.; Sarkar, T.; Edinur, H.A.; Pati, S.; Ray, R.R. Microbiologically synthesized nanoparticles and their role in silencing the biofilm signaling cascade. Front. Microbiol. 2021. [CrossRef]

16. Nag, M.; Lahiri, D.; Sarkar, T.; Ghosh, S.; Dey, A.; Edinur, H.A.; Pati, S.; Ray, R.R. Microbial Fabrication of Nanomaterial and Its Role in Disintegration of Exopolymeric Matrices of Biofilm. Front. Chem. 2021, 9, 369. [CrossRef] 
17. Yao, Y.; Zhou, Y.; Liu, L.; Xu, Y.; Chen, Q.; Wang, Y.; Wu, S.; Deng, Y.; Zhang, J.; Shao, A. Nanoparticle-Based Drug Delivery in Cancer Therapy and Its Role in Overcoming Drug Resistance. Front. Mol. Biosci. 2020, 7, 193. [CrossRef]

18. Yu, Z.; Gao, L.; Chen, K.; Zhang, W.; Zhang, Q.; Li, Q.; Hu, K. Nanoparticles: A New Approach to Upgrade Cancer Diagnosis and Treatment. Nanoscale Res. Lett. 2021, 16, 88. [CrossRef]

19. Andleeb, A.; Andleeb, A.; Asghar, S.; Zaman, G.; Tariq, M.; Mehmood, A.; Nadeem, M.; Hano, C.; Lorenzo, J.M.; Abbasi, B.H. A Systematic Review of Biosynthesized Metallic Nanoparticles as a Promising Anti-Cancer-Strategy. Cancers 2021, $13,2818$. [CrossRef]

20. Ventola, C.L. Progress in Nanomedicine: Approved and Investigational Nanodrugs. Pharm. Ther. 2017, 42, 742-755.

21. Anselmo, A.C.; Mitragotri, S. Nanoparticles in the clinic: An update. Bioeng. Transl. Med. 2019, 4, e10143. [CrossRef]

22. Khan, S.A. Chapter 1-Metal nanoparticles toxicity: Role of physicochemical aspects. In Micro and Nano Technologies; Shah, M.R., Imran, M., Ullah, S.B.T.-M.N., Eds.; Elsevier: Amsterdam, The Netherlands, 2020; pp. 1-11, ISBN 978-0-12-816960-5.

23. Vlamidis, Y.; Voliani, V. Bringing Again Noble Metal Nanoparticles to the Forefront of Cancer Therapy. Front. Bioeng. Biotechnol. 2018, 6, 143. [CrossRef]

24. Sargazi, S.; Hajinezhad, M.R.; Rahdar, A.; Mukhtar, M.; Karamzadeh-Jahromi, M.; Almasi-Kashi, M.; Alikhanzadeh-Arani, S.; Barani, M.; Baino, F. CoNi alloy nanoparticles for cancer theranostics: Synthesis, physical characterization, in vitro and in vivo studies. Appl. Phys. A 2021, 127, 772. [CrossRef]

25. Liu, Y.; Miyoshi, H.; Nakamura, M. Nanomedicine for drug delivery and imaging: A promising avenue for cancer therapy and diagnosis using targeted functional nanoparticles. Int. J. Cancer 2007, 120, 2527-2537. [CrossRef] [PubMed]

26. Dinarvand, R.; Cesar de Morais, P.; D’Emanuele, A. Nanoparticles for Targeted Delivery of Active Agents against Tumor Cells. J. Drug Deliv. 2012, 2012, 528123. [CrossRef]

27. Sharma, A.; Goyal, A.K.; Rath, G. Recent advances in metal nanoparticles in cancer therapy. J. Drug Target. 2018, $26,617-632$. [CrossRef] [PubMed]

28. Lee, K.X.; Shameli, K.; Yew, Y.P.; Teow, S.-Y.; Jahangirian, H.; Rafiee-Moghaddam, R.; Webster, T.J. Recent Developments in the Facile Bio-Synthesis of Gold Nanoparticles (AuNPs) and Their Biomedical Applications. Int. J. Nanomed. 2020, 15, 275-300. [CrossRef] [PubMed]

29. Al Saqr, A.; Khafagy, E.-S.; Alalaiwe, A.; Aldawsari, M.F.; Alshahrani, S.M.; Anwer, M.K.; Khan, S.; Lila, A.S.A.; Arab, H.H.; Hegazy, W.A.H. Synthesis of Gold Nanoparticles by Using Green Machinery: Characterization and In Vitro Toxicity. Nanomaterials 2021, 11, 808. [CrossRef]

30. Arshad, R.; Barani, M.; Rahdar, A.; Sargazi, S.; Cucchiarini, M.; Pandey, S.; Kang, M. Multi-Functionalized Nanomaterials and Nanoparticles for Diagnosis and Treatment of Retinoblastoma. Biosensors 2021, 11, 97. [CrossRef] [PubMed]

31. Koushki, K.; Keshavarz Shahbaz, S.; Keshavarz, M.; Bezsonov, E.E.; Sathyapalan, T.; Sahebkar, A. Gold Nanoparticles: Multifaceted Roles in the Management of Autoimmune Disorders. Biomolecules 2021, 11, 1289. [CrossRef]

32. Piktel, E.; Suprewicz, Ł.; Depciuch, J.; Chmielewska, S.; Skłodowski, K.; Daniluk, T.; Król, G.; Kołat-Brodecka, P.; Bijak, P.; Pajor-Świerzy, A.; et al. Varied-shaped gold nanoparticles with nanogram killing efficiency as potential antimicrobial surface coatings for the medical devices. Sci. Rep. 2021, 11, 12546. [CrossRef]

33. Hassanisaadi, M.; Bonjar, G.H.; Rahdar, A.; Pandey, S.; Hosseinipour, A.; Abdolshahi, R. Environmentally Safe Biosynthesis of Gold Nanoparticles Using Plant Water Extracts. Nanomaterials 2021, 11, 2033. [CrossRef] [PubMed]

34. Perveen, K.; Husain, F.M.; Qais, F.A.; Khan, A.; Razak, S.; Afsar, T.; Alam, P.; Almajwal, A.M.; Abulmeaty, M.M.A. MicrowaveAssisted Rapid Green Synthesis of Gold Nanoparticles Using Seed Extract of Trachyspermum ammi: ROS Mediated Biofilm Inhibition and Anticancer Activity. Biomolecules 2021, 11, 197. [CrossRef] [PubMed]

35. Rabha, B.; Bharadwaj, K.K.; Boro, N.; Ghosh, A.; Gogoi, S.K.; Varma, R.S.; Baishya, D. Cheilocostus speciosus extract-assisted

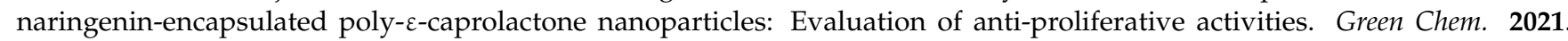
[CrossRef]

36. Nanomed, G.J.; Singh, J.; Singh, T.; Rawat, M. Green Synthesis of Silver Nanoparticles via Various Plant Extracts for Anti-Cancer Applications. Glob. J. Nanomed. 2017, 2, 2-5. [CrossRef]

37. Kajani, A.A.; Bordbar, A.-K.; Zarkesh Esfahani, S.H.; Razmjou, A. Gold nanoparticles as potent anticancer agent: Green synthesis, characterization, and in vitro study. RSC Adv. 2016, 6, 63973-63983. [CrossRef]

38. Sharma, N.; Bhatt, G.; Kothiyal, P. Gold Nanoparticles synthesis, properties, and forthcoming applications: A review. Indian J. Pharm. Biol. Res. 2015, 3, 13-27. [CrossRef]

39. Jana, N.R.; Gearheart, L.; Murphy, C.J. Seeding Growth for Size Control of 5-40 nm Diameter Gold Nanoparticles. Langmuir 2001, 17, 6782-6786. [CrossRef]

40. Brust, M.; Walker, M.; Bethell, D.; Schiffrin, D.J.; Whyman, R. Synthesis of thiol-derivatised gold nanoparticles in a two-phase Liquid-Liquid system. J. Chem. Soc. Chem. Commun. 1994, 801-802. [CrossRef]

41. Turkevich, J.; Stevenson, P.C.; Hillier, J. A study of the nucleation and growth processes in the synthesis of colloidal gold. Discuss. Faraday Soc. 1951, 11, 55-75. [CrossRef]

42. Frens, G. Controlled Nucleation for the Regulation of the Particle Size in Monodisperse Gold Suspensions. Nat. Phys. Sci. 1973, 241, 20-22. [CrossRef]

43. Zhao, L.; Jiang, D.; Cai, Y.; Ji, X.; Xie, R.; Yang, W. Tuning the size of gold nanoparticles in the citrate reduction by chloride ions. Nanoscale 2012, 4, 5071-5076. [CrossRef] [PubMed] 
44. Kim, J.H.; Kim, M.H.; Jo, D.H.; Yu, Y.S.; Lee, T.G.; Kim, J.H. The inhibition of retinal neovascularization by gold nanoparticles via suppression of VEGFR-2 activation. Biomaterials 2011, 32, 1865-1871. [CrossRef]

45. Zobel, M.; Neder, R.B.; Kimber, S.A. Universal solvent restructuring induced by colloidal nanoparticles. Science 2015, 347, $292-294$. [CrossRef] [PubMed]

46. Zheng, N.; Fan, J.; Stucky, G.D. One-Step One-Phase Synthesis of Monodisperse Noble-Metallic Nanoparticles and Their Colloidal Crystals. J. Am. Chem. Soc. 2006, 128, 6550-6551. [CrossRef]

47. Song, J.; Kim, D.; Lee, D. Size Control in the Synthesis of 1-6 nm Gold Nanoparticles via Solvent-Controlled Nucleation. Langmuir 2011, 27, 13854-13860. [CrossRef]

48. Stanglmair, C.; Scheeler, S.P.; Pacholski, C. Seeding Growth Approach to Gold Nanoparticles with Diameters Ranging from 10 to 80 Nanometers in Organic Solvent. Eur. J. Inorg. Chem. 2014, 2014, 3633-3637. [CrossRef]

49. Ziegler, C.; Eychmüller, A. Seeded Growth Synthesis of Uniform Gold Nanoparticles with Diameters of $15-300 \mathrm{~nm}$. J. Phys. Chem. C 2011, 115, 4502-4506. [CrossRef]

50. Park, K.; Koerner, H.; Vaia, R.A. Depletion-Induced Shape and Size Selection of Gold Nanoparticles. Nano Lett. 2010, 10, 1433-1439. [CrossRef]

51. Zhang, J.; Liu, H.; Wang, Z.; Ming, N. Shape-Selective Synthesis of Gold Nanoparticles with Controlled Sizes, Shapes, and Plasmon Resonances. Adv. Funct. Mater. 2007, 17, 3295-3303. [CrossRef]

52. Wang, S.; Chen, K.-J.; Wu, T.-H.; Wang, H.; Lin, W.-Y.; Ohashi, M.; Chiou, P.-Y.; Tseng, H.-R. Photothermal effects of supramolecularly assembled gold nanoparticles for the targeted treatment of cancer cells. Angew. Chem. Int. Ed. Engl. 2010, 49, 3777-3781. [CrossRef]

53. Wang, D.; Schaaf, P. Nanoporous gold nanoparticles. J. Mater. Chem. 2012, 22, 5344-5348. [CrossRef]

54. Himmelhaus, M.; Takei, H. Cap-shaped gold nanoparticles for an optical biosensor. Sens. Actuators B Chem. 2000, 63, 24-30. [CrossRef]

55. Robertson, J.D.; Rizzello, L.; Avila-Olias, M.; Gaitzsch, J.; Contini, C.; Magoń, M.S.; Renshaw, S.A.; Battaglia, G. Purification of Nanoparticles by Size and Shape. Sci. Rep. 2016, 6, 27494. [CrossRef]

56. Paino, I.M.M.; Marangoni, V.S.; de Oliveira, R.D.C.S.; Antunes, L.M.G.; Zucolotto, V. Cyto and genotoxicity of gold nanoparticles in human hepatocellular carcinoma and peripheral blood mononuclear cells. Toxicol. Lett. 2012, 215, 119-125. [CrossRef]

57. Minati, L.; Benetti, F.; Chiappini, A.; Speranza, G. One-step synthesis of star-shaped gold nanoparticles. Colloids Surf. A Physicochem. Eng. Asp. 2014, 441, 623-628. [CrossRef]

58. Amendola, V.; Pilot, R.; Frasconi, M.; Maragò, O.M.; Iatì, M.A. Surface plasmon resonance in gold nanoparticles: A review. J. Phys. Condens. Matter 2017, 29, 203002. [CrossRef] [PubMed]

59. Huang, X.; El-Sayed, M.A. Gold nanoparticles: Optical properties and implementations in cancer diagnosis and photothermal therapy. J. Adv. Res. 2010, 1, 13-28. [CrossRef]

60. El-Brolossy, T.A.; Abdallah, T.; Mohamed, M.B.; Abdallah, S.; Easawi, K.; Negm, S.; Talaat, H. Shape and size dependence of the surface plasmon resonance of gold nanoparticles studied by Photoacoustic technique. Eur. Phys. J. Spec. Top. 2008, 153, 361-364. [CrossRef]

61. Majles Ara, M.H.; Dehghani, Z.; Sahraei, R.; Daneshfar, A.; Javadi, Z.; Divsar, F. Diffraction patterns and nonlinear optical properties of gold nanoparticles. J. Quant. Spectrosc. Radiat. Transf. 2012, 113, 366-372. [CrossRef]

62. Nehl, C.L.; Hafner, J.H. Shape-dependent plasmon resonances of gold nanoparticles. J. Mater. Chem. 2008, 18, 2415-2419. [CrossRef]

63. Rechberger, W.; Hohenau, A.; Leitner, A.; Krenn, J.R.; Lamprecht, B.; Aussenegg, F.R. Optical properties of two interacting gold nanoparticles. Opt. Commun. 2003, 220, 137-141. [CrossRef]

64. Bai, X.; Wang, Y.; Song, Z.; Feng, Y.; Chen, Y.; Zhang, D.; Feng, L. The Basic Properties of Gold Nanoparticles and their Applications in Tumor Diagnosis and Treatment. Int. J. Mol. Sci. 2020, 21, 2480. [CrossRef]

65. Schmid, G.; Simon, U. Gold nanoparticles: Assembly and electrical properties in 1-3 dimensions. Chem. Commun. 2005, 697-710. [CrossRef]

66. Teranishi, T. Fabrication and electronic properties of gold nanoparticle superlattices. Comptes Rendus Chim. 2003, 6, 979-987. [CrossRef]

67. Asnag, G.M.; Oraby, A.H.; Abdelghany, A.M. Green synthesis of gold nanoparticles and its effect on the optical, thermal and electrical properties of carboxymethyl cellulose. Compos. Part. B Eng. 2019, 172, 436-446. [CrossRef]

68. Li, S.; Shen, Y.; Xie, A.; Yu, X.; Qiu, L.; Zhang, L.; Zhang, Q. Green synthesis of silver nanoparticles using Capsicum annuum L. extract. Green Chem. 2007, 9, 852-858. [CrossRef]

69. Pardo-Yissar, V.; Gabai, R.; Shipway, A.N.; Bourenko, T.; Willner, I. Gold Nanoparticle/Hydrogel Composites with SolventSwitchable Electronic Properties. Adv. Mater. 2001, 13, 1320-1323. [CrossRef]

70. Chan, K.-Y.; Yang, D.; Demir, B.; Mouritz, A.P.; Lin, H.; Jia, B.; Lau, K.-T. Boosting the electrical and mechanical properties of structural dielectric capacitor composites via gold nanoparticle doping. Compos. Part. B Eng. 2019, 178, 107480. [CrossRef]

71. Choi, K.; Yu, C. Highly Doped Carbon Nanotubes with Gold Nanoparticles and Their Influence on Electrical Conductivity and Thermopower of Nanocomposites. PLoS ONE 2012, 7, e44977. [CrossRef]

72. Hamza, S.; Ignaszak, A.; Kiani, A. Synthesis of Electrical Conductive Silica Nanofiber/Gold Nanoparticle Composite by Laser Pulses and Sputtering Technique. Nanoscale Res. Lett. 2017, 12, 432. [CrossRef] [PubMed] 
73. Birla, S.S.; Tiwari, V.V.; Gade, A.K.; Ingle, A.P.; Yadav, A.P.; Rai, M.K. Fabrication of silver nanoparticles by Phoma glomerata and its combined effect against Escherichia coli, Pseudomonas aeruginosa and Staphylococcus aureus. Lett. Appl. Microbiol. 2009, 48, 173-179. [CrossRef] [PubMed]

74. Rai, M.; Yadav, A.; Gade, A. Current [corrected] trends in phytosynthesis of metal nanoparticles. Crit. Rev. Biotechnol. 2008, 28, 277-284. [CrossRef]

75. Ahmed, S.; Annu; Ikram, S.; Yudha, S.S. Biosynthesis of gold nanoparticles: A green approach. J. Photochem. Photobiol. B Biol. 2016, 161, 141-153. [CrossRef]

76. Marslin, G.; Siram, K.; Maqbool, Q.; Selvakesavan, R.K.; Kruszka, D.; Kachlicki, P.; Franklin, G. Secondary Metabolites in the Green Synthesis of Metallic Nanoparticles. Materials 2018, 11, 940. [CrossRef]

77. Singh, J.; Dutta, T.; Kim, K.H.; Rawat, M.; Samddar, P.; Kumar, P. “Green” synthesis of metals and their oxide nanoparticles: Applications for environmental remediation. J. Nanobiotechnology 2018, 16, 1-24. [CrossRef]

78. Dauthal, P.; Mukhopadhyay, M. Noble Metal Nanoparticles: Plant-Mediated Synthesis, Mechanistic Aspects of Synthesis, and Applications. Ind. Eng. Chem. Res. 2016, 55, 9557-9577. [CrossRef]

79. Shah, M.; Fawcett, D.; Sharma, S.; Tripathy, S.K.; Poinern, G.E.J. Green Synthesis of Metallic Nanoparticles via Biological Entities. Materials 2015, 8, 7278-7308. [CrossRef]

80. Mittal, A.K.; Chisti, Y.; Banerjee, U.C. Synthesis of metallic nanoparticles using plant extracts. Biotechnol. Adv. 2013, 31, 346-356. [CrossRef]

81. Kim, H.; Seo, Y.S.; Kim, K.; Han, J.W.; Park, Y.; Cho, S. Concentration Effect of Reducing Agents on Green Synthesis of Gold Nanoparticles: Size, Morphology, and Growth Mechanism. Nanoscale Res. Lett. 2016, 11, 230. [CrossRef] [PubMed]

82. Zhang, D.; Ma, X.; Gu, Y.; Huang, H.; Zhang, G. Green Synthesis of Metallic Nanoparticles and Their Potential Applications to Treat Cancer. Front. Chem. 2020, 8, 799. [CrossRef]

83. Mude, N.; Ingle, A.; Gade, A.; Rai, M. Synthesis of Silver Nanoparticles Using Callus Extract of Carica papaya-A First Report. J. Plant. Biochem. Biotechnol. 2009, 18, 83-86. [CrossRef]

84. Sundararajan, B.; Ranjitha Kumari, B.D. Novel synthesis of gold nanoparticles using Artemisia vulgaris L. leaf extract and their efficacy of larvicidal activity against dengue fever vector Aedes aegypti L. J. Trace Elem. Med. Biol. Organ Soc. Miner. Trace Elem. 2017, 43, 187-196. [CrossRef] [PubMed]

85. Vanaraj, S.; Jabastin, J.; Sathiskumar, S.; Preethi, K. Production and Characterization of Bio-AuNPs to Induce Synergistic Effect Against Multidrug Resistant Bacterial Biofilm. J. Clust. Sci. 2017, 28, 227-244. [CrossRef]

86. Alam, M.N.; Das, S.; Batuta, S.; Roy, N.; Chatterjee, A.; Mandal, D.; Begum, N.A. Murraya koenegii Spreng. Leaf Extract: An Efficient Green Multifunctional Agent for the Controlled Synthesis of Au Nanoparticles. ACS Sustain. Chem. Eng. 2014, 2, 652-664. [CrossRef]

87. Vijayashree, I.S.; Niranjana, P.; Prabhu, G.; Sureshbabu, V.V.; Manjanna, J. Conjugation of Au Nanoparticles with Chlorambucil for Improved Anticancer Activity. J. Clust. Sci. 2017, 28, 133-148. [CrossRef]

88. Karuppiah, C.; Palanisamy, S.; Chen, S.-M.; Emmanuel, R.; Muthupandi, K.; Prakash, P. Green synthesis of gold nanoparticles and its application for the trace level determination of painter's colic. RSC Adv. 2015, 5, 16284-16291. [CrossRef]

89. Gopinath, K.; Venkatesh, K.S.; Ilangovan, R.; Sankaranarayanan, K.; Arumugam, A. Green synthesis of gold nanoparticles from leaf extract of Terminalia arjuna, for the enhanced mitotic cell division and pollen germination activity. Ind. Crops Prod. 2013, 50, 737-742. [CrossRef]

90. Arunachalam, K.D.; Annamalai, S.K.; Hari, S. One-step green synthesis and characterization of leaf extract-mediated biocompatible silver and gold nanoparticles from Memecylon umbellatum. Int. J. Nanomed. 2013, 8, 1307-1315. [CrossRef]

91. Philip, D. Rapid green synthesis of spherical gold nanoparticles using Mangifera indica leaf. Spectrochim. Acta Part. A Mol. Biomol. Spectrosc. 2010, 77, 807-810. [CrossRef]

92. Khalil, M.M.H.; Ismail, E.H.; El-Magdoub, F. Biosynthesis of Au nanoparticles using olive leaf extract: 1st Nano Updates. Arab. J. Chem. 2012, 5, 431-437. [CrossRef]

93. Abhijith, K.S.; Thakur, M.S. Application of green synthesis of gold nanoparticles for sensitive detection of aflatoxin B1 based on metal enhanced fluorescence. Anal. Methods 2012, 4, 4250-4256. [CrossRef]

94. Kumar, V.G.; Gokavarapu, S.D.; Rajeswari, A.; Dhas, T.S.; Karthick, V.; Kapadia, Z.; Shrestha, T.; Barathy, I.A.; Roy, A.; Sinha, S. Facile green synthesis of gold nanoparticles using leaf extract of antidiabetic potent Cassia auriculata. Colloids Surf. B. Biointerfaces 2011, 87, 159-163. [CrossRef]

95. Nagajyothi, P.C.; Lee, S.E.; An, M.; Lee, K.D. Green synthesis of silver and gold nanoparticles using Lonicera Japonica flower extract. Bull. Korean Chem. Soc. 2012, 33, 2609-2612. [CrossRef]

96. Das, R.K.; Gogoi, N.; Bora, U. Green synthesis of gold nanoparticles using Nyctanthes arbortristis flower extract. Bioprocess. Biosyst. Eng. 2011, 34, 615-619. [CrossRef]

97. Karthika, V.; Arumugam, A.; Gopinath, K.; Kaleeswarran, P.; Govindarajan, M.; Alharbi, N.S.; Kadaikunnan, S.; Khaled, J.M.; Benelli, G. Guazuma ulmifolia bark-synthesized Ag, Au and Ag/Au alloy nanoparticles: Photocatalytic potential, DNA/protein interactions, anticancer activity and toxicity against 14 species of microbial pathogens. J. Photochem. Photobiol. B 2017, 167, 189-199. [CrossRef]

98. Bahram, M.; Mohammadzadeh, E. Green synthesis of gold nanoparticles with willow tree bark extract: A sensitive colourimetric sensor for cysteine detection. Anal. Methods 2014, 6, 6916-6924. [CrossRef] 
99. Emmanuel, R.; Karuppiah, C.; Chen, S.-M.; Palanisamy, S.; Padmavathy, S.; Prakash, P. Green synthesis of gold nanoparticles for trace level detection of a hazardous pollutant (nitrobenzene) causing Methemoglobinaemia. J. Hazard. Mater. 2014, 279, 117-124. [CrossRef] [PubMed]

100. Vijayakumar, S.; Vaseeharan, B.; Malaikozhundan, B.; Gopi, N.; Ekambaram, P.; Pachaiappan, R.; Velusamy, P.; Murugan, K.; Benelli, G.; Suresh Kumar, R.; et al. Therapeutic effects of gold nanoparticles synthesized using Musa paradisiaca peel extract against multiple antibiotic resistant Enterococcus faecalis biofilms and human lung cancer cells (A549). Microb. Pathog. 2017, 102, 173-183. [CrossRef] [PubMed]

101. Yang, N.; WeiHong, L.; Hao, L. Biosynthesis of Au nanoparticles using agricultural waste mango peel extract and its in vitro cytotoxic effect on two normal cells. Mater. Lett. 2014, 134, 67-70. [CrossRef]

102. Suganthy, N.; Sri Ramkumar, V.; Pugazhendhi, A.; Benelli, G.; Archunan, G. Biogenic synthesis of gold nanoparticles from Terminalia arjuna bark extract: Assessment of safety aspects and neuroprotective potential via antioxidant, anticholinesterase, and antiamyloidogenic effects. Environ. Sci. Pollut. Res. Int. 2018, 25, 10418-10433. [CrossRef]

103. Kumar, B.; Smita, K.; Cumbal, L.; Debut, A. Extracellular biofabrication of gold nanoparticles by using Lantana camara berry extract. Inorg. Nano-Metal. Chem. 2017, 47, 138-142. [CrossRef]

104. Sujitha, M.V.; Kannan, S. Green synthesis of gold nanoparticles using Citrus fruits (Citrus limon, Citrus reticulata and Citrus sinensis) aqueous extract and its characterization. Spectrochim. Acta. A Mol. Biomol. Spectrosc. 2013, 102, 15-23. [CrossRef]

105. Yu, J.; Xu, D.; Guan, H.N.; Wang, C.; Huang, L.K.; Chi, D.F. Facile one-step green synthesis of gold nanoparticles using Citrus maxima aqueous extracts and its catalytic activity. Mater. Lett. 2016, 166, 110-112. [CrossRef]

106. Ghodake, G.; Lee, D. Green synthesis of gold nanostructures using pear extract as effective reducing and coordinating agent. Korean J. Chem. Eng. 2011, 28, 2329-2335. [CrossRef]

107. Rodríguez-León, E.; Rodríguez-Vázquez, B.E.; Martínez-Higuera, A.; Rodríguez-Beas, C.; Larios-Rodríguez, E.; Navarro, R.E.; López-Esparza, R.; Iñiguez-Palomares, R.A. Synthesis of Gold Nanoparticles Using Mimosa tenuiflora Extract, Assessments of Cytotoxicity, Cellular Uptake, and Catalysis. Nanoscale Res. Lett. 2019, 14, 334. [CrossRef]

108. Islam, N.U.; Jalil, K.; Shahid, M.; Muhammad, N.; Rauf, A. Pistacia integerrima gall extract mediated green synthesis of gold nanoparticles and their biological activities. Arab. J. Chem. 2019, 12, 2310-2319. [CrossRef]

109. Jayaseelan, C.; Ramkumar, R.; Rahuman, A.A.; Perumal, P. Green synthesis of gold nanoparticles using seed aqueous extract of Abelmoschus esculentus and its antifungal activity. Ind. Crops Prod. 2013, 45, 423-429. [CrossRef]

110. Fazal, S.; Jayasree, A.; Sasidharan, S.; Koyakutty, M.; Nair, S.V.; Menon, D. Green Synthesis of Anisotropic Gold Nanoparticles for Photothermal Therapy of Cancer. ACS Appl. Mater. Interfaces 2014, 6, 8080-8089. [CrossRef] [PubMed]

111. Cabrera, F.C.; Mohan, H.; dos Santos, R.J.; Agostini, D.L.S.; Aroca, R.F.; Rodríguez-Pérez, M.A.; Job, A.E. Green Synthesis of Gold Nanoparticles with Self-Sustained Natural Rubber Membranes. J. Nanomater. 2013, 2013, 710902. [CrossRef]

112. Velmurugan, P.; Anbalagan, K.; Manosathyadevan, M.; Lee, K.-J.; Cho, M.; Lee, S.-M.; Park, J.-H.; Oh, S.-G.; Bang, K.-S.; Oh, B.-T. Green synthesis of silver and gold nanoparticles using Zingiber officinale root extract and antibacterial activity of silver nanoparticles against food pathogens. Bioprocess. Biosyst. Eng. 2014, 37, 1935-1943. [CrossRef]

113. Nadagouda, M.N.; Iyanna, N.; Lalley, J.; Han, C.; Dionysiou, D.D.; Varma, R.S. Synthesis of Silver and Gold Nanoparticles Using Antioxidants from Blackberry, Blueberry, Pomegranate, and Turmeric Extracts. ACS Sustain. Chem. Eng. 2014, 2, 1717-1723. [CrossRef]

114. Leonard, K.; Ahmmad, B.; Okamura, H.; Kurawaki, J. In situ green synthesis of biocompatible ginseng capped gold nanoparticles with remarkable stability. Colloids Surf. B. Biointerfaces 2011, 82, 391-396. [CrossRef]

115. Ganesan, R.M.; Gurumallesh Prabu, H. Synthesis of gold nanoparticles using herbal Acorus calamus rhizome extract and coating on cotton fabric for antibacterial and UV blocking applications. Arab. J. Chem. 2019, 12, 2166-2174. [CrossRef]

116. Sathiyanarayanan, G.; Vignesh, V.; Saibaba, G.; Vinothkanna, A.; Dineshkumar, K.; Viswanathan, M.B.; Selvin, J. Synthesis of carbohydrate polymer encrusted gold nanoparticles using bacterial exopolysaccharide: A novel and greener approach. RSC Adv. 2014, 4, 22817-22827. [CrossRef]

117. Rajan, A.; Vilas, V.; Philip, D. Studies on catalytic, antioxidant, antibacterial and anticancer activities of biogenic gold nanoparticles. J. Mol. Liq. 2015, 212, 331-339. [CrossRef]

118. Paul, B.; Bhuyan, B.; Purkayastha, D.D.; Vadivel, S.; Dhar, S.S. One-pot green synthesis of gold nanoparticles and studies of their anticoagulative and photocatalytic activities. Mater. Lett. 2016, 185, 143-147. [CrossRef]

119. Gan, P.P.; Ng, S.H.; Huang, Y.; Li, S.F.Y. Green synthesis of gold nanoparticles using palm oil mill effluent (POME): A low-cost and eco-friendly viable approach. Bioresour. Technol. 2012, 113, 132-135. [CrossRef]

120. Aromal, S.A.; Vidhu, V.K.; Philip, D. Green synthesis of well-dispersed gold nanoparticles using Macrotyloma uniflorum. Spectrochim. Acta Part. A Mol. Biomol. Spectrosc. 2012, 85, 99-104. [CrossRef]

121. Chen, Y.-S.; Hung, Y.-C.; Liau, I.; Huang, G.S. Assessment of the In Vivo Toxicity of Gold Nanoparticles. Nanoscale Res. Lett. 2009, 4, 858-864. [CrossRef]

122. Kumar, B. Green Synthesis of Gold, Silver, and Iron Nanoparticles for the Degradation of Organic Pollutants in Wastewater. J. Compos. Sci. 2021, 5, 219. [CrossRef]

123. Ganaie, S.U.; Abbasi, T.; Anuradha, J.; Abbasi, S.A. Biomimetic synthesis of silver nanoparticles using the amphibious weed ipomoea and their application in pollution control. J. King Saud Univ.-Sci. 2014, 26, 222-229. [CrossRef] 
124. Teimuri-mofrad, R.; Hadi, R.; Tahmasebi, B.; Farhoudian, S.; Mehravar, M.; Nasiri, R. Green synthesis of gold nanoparticles using plant extract: Mini-review. Nanochemistry Res. 2017, 2, 8-19. [CrossRef]

125. Siddiqi, K.S.; Husen, A. Recent advances in plant-mediated engineered gold nanoparticles and their application in biological system. J. Trace Elem. Med. Biol. Organ Soc. Miner. Trace Elem. 2017, 40, 10-23. [CrossRef]

126. Chen, Y.; Wu, X.; Lv, L.; Li, F.; Liu, Z.; Kong, Q.; Li, C. Enhancing reducing ability of $\alpha$-zein by fibrillation for synthesis of Au nanocrystals with continuous flow catalysis. J. Colloid Interface Sci. 2017, 491, 37-43. [CrossRef]

127. Lee, J.; Kim, H.Y.; Zhou, H.; Hwang, S.; Koh, K.; Han, D.-W.; Lee, J. Green synthesis of phytochemical-stabilized Au nanoparticles under ambient conditions and their biocompatibility and antioxidative activity. J. Mater. Chem. 2011, 21, 13316-13326. [CrossRef]

128. Cai, W.; Gao, T.; Hong, H. Applications of gold nanoparticles in cancer nanotechnology. Nanotechnol. Sci. Appl. $2008,1,17$. [CrossRef]

129. Mu, L.; Sprando, R.L. Application of Nanotechnology in Cosmetics. Pharm. Res. 2010, 27, 1746-1749. [CrossRef]

130. Khan, T.; Ullah, N.; Khan, M.A.; Mashwani, Z.-R.; Nadhman, A. Plant-based gold nanoparticles; a comprehensive review of the decade-long research on synthesis, mechanistic aspects and diverse applications. Adv. Colloid Interface Sci. 2019, $272,102017$. [CrossRef]

131. MR Kamala Priya, P.I. Anticancer studies of the synthesized gold nanoparticles against MCF 7 breast cancer cell lines. Appl. Nanosci. 2015, 5, 443. [CrossRef]

132. Karuppaiya, P.; Satheeshkumar, E.; Chao, W.T.; Kao, L.Y.; Chen, E.C.F.; Tsay, H.S. Anti-metastatic activity of biologically synthesized gold nanoparticles on human fibrosarcoma cell line HT-1080. Colloids Surf. B Biointerfaces 2013, 110, 163-170. [CrossRef]

133. Virmani, I.; Sasi, C.; Priyadarshini, E.; Kumar, R.; Sharma, S.K.; Singh, G.P.; Pachwarya, R.B.; Paulraj, R.; Barabadi, H.; Saravanan, M.; et al. Comparative Anticancer Potential of Biologically and Chemically Synthesized Gold Nanoparticles. J. Clust. Sci. 2020, 31, 867-876. [CrossRef]

134. UK Parida, B.B.P.N. Green synthesis and characterization of gold nanoparticles using onion (Allium cepa) extract. World J. Nano Sci. Eng. 2011, 1, 93-98. [CrossRef]

135. Mukherjee, S.; Sau, S.C.; Madhuri, D.; Bollu, V.S.; Madhusudana, K.; Sreedhar, B.; Banerjee, R.; Patra, C.R. Green Synthesis and Characterization of Monodispersed Gold Nanoparticles: Toxicity Study, Delivery of Doxorubicin and Its Bio-Distribution in Mouse Model. J. Biomed. Nanotechnol. 2016, 121, 165-181. [CrossRef] [PubMed]

136. Ahmad, N.; Bhatnagar, S.; Saxena, R.; Iqbal, D.; Ghosh, A.K.; Dutta, R. Biosynthesis and characterization of gold nanoparticles: Kinetics, in vitro and in vivo study. Mater. Sci. Eng. C Mater. Biol. Appl. 2017, 78, 553-564. [CrossRef]

137. Botteon, C.E.A.; Silva, L.B.; Ccana-Ccapatinta, G.V.; Silva, T.S.; Ambrosio, S.R.; Veneziani, R.C.S.; Bastos, J.K.; Marcato, P.D. Biosynthesis and characterization of gold nanoparticles using Brazilian red propolis and evaluation of its antimicrobial and anticancer activities. Sci. Rep. 2021, 11, 1974. [CrossRef] [PubMed]

138. Wu, T.; Duan, X.; Hu, C.; Wu, C.; Chen, X.; Huang, J.; Liu, J.; Cui, S. Synthesis and characterization of gold nanoparticles from Abies spectabilis extract and its anticancer activity on bladder cancer T24 cells. Artif. Cells Nanomed. Biotechnol. 2019, 47, 512-523. [CrossRef] [PubMed]

139. Patra, S.; Mukherjee, S.; Barui, A.K.; Ganguly, A.; Sreedhar, B.; Patra, C.R. Green synthesis, characterization of gold and silver nanoparticles and their potential application for cancer therapeutics. Mater. Sci. Eng. C Mater. Biol. Appl. 2015, 53, 298-309. [CrossRef] [PubMed]

140. Yas, R.M.; Ghafoor, D.A.; Saeed, M.A. Anticancer effect of green synthesized gold nanoparticles using orchid extract and their characterizations on breast cancer AMJ-13 Cell line. Syst. Rev. Pharm. 2021, 12, 500-505. [CrossRef]

141. Sun, B.; Hu, N.; Han, L.; Pi, Y.; Gao, Y.; Chen, K. Anticancer activity of green synthesised gold nanoparticles from Marsdenia tenacissima inhibits A549 cell proliferation through the apoptotic pathway. Artif. Cells Nanomed. Biotechnol. 2019, 47, 4012-4019. [CrossRef] [PubMed]

142. Datkhile, K.D.; Patil, S.R.; Durgawale, P.P.; Patil, M.N.; Hinge, D.D.; Jagdale, N.J.; Deshmukh, V.N.; More, A.L. Biogenic synthesis of gold nanoparticles using Argemone mexicana L. and their cytotoxic and genotoxic effects on human colon cancer cell line (HCT-15). J. Genet. Eng. Biotechnol. 2021, 19, 9. [CrossRef] [PubMed]

143. Geetha, R.; Ashokkumar, T.; Tamilselvan, S.; Govindaraju, K.; Sadiq, M.; Singaravelu, G. Green synthesis of gold nanoparticles and their anticancer activity. Cancer Nanotechnol. 2013, 4, 91-98. [CrossRef] [PubMed]

144. Chokkalingam, M.; Singh, P.; Huo, Y.; Soshnikova, V.; Ahn, S.; Kang, J.; Mathiyalagan, R.; Kim, Y.J.; Yang, D.C. Facile synthesis of $\mathrm{Au}$ and Ag nanoparticles using fruit extract of Lycium chinense and their anticancer activity. J. Drug Deliv. Sci. Technol. 2019, 49, 308-315. [CrossRef]

145. Reddy, M. Synthesis of gold nanoparticles from the flower extracts of tabebuia argentiea and their anticancer activity. Int. J. Pharm. Biol. Sci. 2017, 8, 379-383.

146. Wang, C.; Mathiyalagan, R.; Kim, Y.J.; Castro-Aceituno, V.; Singh, P.; Ahn, S.; Wang, D.; Yang, D.C. Rapid green synthesis of silver and gold nanoparticles using Dendropanax morbifera leaf extract and their anticancer activities. Int. J. Nanomed. 2016, 11, 3691-3701. [CrossRef]

147. Vinosha, M.; Palanisamy, S.; Muthukrishnan, R.; Selvam, S.; Kannapiran, E.; You, S.; Prabhu, N.M. Biogenic synthesis of gold nanoparticles from Halymenia dilatata for pharmaceutical applications: Antioxidant, anti-cancer and antibacterial activities. Process. Biochem. 2019, 85, 219-229. [CrossRef] 
148. Dorosti, N.; Jamshidi, F. Plant-mediated gold nanoparticles by Dracocephalum kotschyi as anticholinesterase agent: Synthesis, characterization, and evaluation of anticancer and antibacterial activity. J. Appl. Biomed. 2016, 14, 235-245. [CrossRef]

149. Ajdari, Z.; Rahman, H.; Shameli, K.; Abdullah, R.; Abd Ghani, M.; Yeap, S.; Abbasiliasi, S.; Ajdari, D.; Ariff, A. Novel Gold Nanoparticles Reduced by Sargassum glaucescens: Preparation, Characterization and Anticancer Activity. Molecules 2016, $21,123$. [CrossRef]

150. Valsalam, S.; Agastian, P.; Esmail, G.A.; Ghilan, A.-K.M.; Al-Dhabi, N.A.; Arasu, M.V. Biosynthesis of silver and gold nanoparticles using Musa acuminata colla flower and its pharmaceutical activity against bacteria and anticancer efficacy. J. Photochem. Photobiol. B Biol. 2019, 201, 111670. [CrossRef]

151. Vijayakumar, S. Eco-friendly synthesis of gold nanoparticles using fruit extracts and in vitro anticancer studies. J. Saudi Chem. Soc. 2019, 23, 753-761. [CrossRef]

152. Kumar, P.S.; Jeyalatha, M.V.; Malathi, J.; Ignacimuthu, S. Anticancer effects of one-pot synthesized biogenic gold nanoparticles (Mc-AuNps) against laryngeal carcinoma. J. Drug Deliv. Sci. Technol. 2018, 44, 118-128. [CrossRef]

153. Gothainayagi, A.; Josephine, N.M. Characterization of green synthesized gold nanoparticles from Nigella sativa oil and evaluation of its antibacterial and anticancer activity. J. Crit. Rev. 2020, 7, 1664-1679.

154. Balashanmugam, P.; Mosachristas, K.; Kowsalya, E. In vitro cytotoxicity and antioxidant evaluation of biogenic synthesized gold nanoparticles from Marsilea quadrifolia on lung and ovarian cancer cells. Int. J. Appl. Pharm. 2018, 10, 153-158. [CrossRef]

155. Gautam, P.K.; Kumar, S.; Tomar, M.S.; Singh, R.K.; Acharya, A. Biologically Synthesized Gold Nanoparticles using Ocimum sanctum (Tulsi Leaf Extract) Induced Anti-Tumor Response in a T Cell Daltons Lymphoma. J. Cell Sci. Ther. 2017, 8, 2. [CrossRef]

156. Mukundan, D.; Mohankumar, R.; Vasanthakumari, R. Comparative study of synthesized silver and gold nanoparticles using leaves extract of Bauhinia tomentosa Linn and their anticancer efficacy. Bull. Mater. Sci. 2017, 40, 335-344. [CrossRef]

157. Li, Y.M.; Wang, Y.Y.; Cheng, B.N. In-vitro cytotoxicity of biosynthesized gold nanoparticles against thyroid cancer cell lines. Trop. J. Pharm. Res. 2017, 16, 1523-1528. [CrossRef]

158. Rabori, M.S.; Karimabad, M.N.; Hajizadeh, M.R. Facile, low-cost and rapid phytosynthesis of stable and eco-friendly gold nanoparticles using green walnut shell and study of their anticancer potential. World Cancer Res. J. 2021, 8, 1-8.

159. Abel, E.E.; John Poonga, P.R.; Panicker, S.G. Characterization and in vitro studies on anticancer, antioxidant activity against colon cancer cell line of gold nanoparticles capped with Cassia tora SM leaf extract. Appl. Nanosci. 2016, 6, 121-129. [CrossRef]

160. Patil, M.P.; Ngabire, D.; Thi, H.H.P.; Kim, M.-D.; Kim, G.-D. Eco-friendly Synthesis of Gold Nanoparticles and Evaluation of Their Cytotoxic Activity on Cancer Cells. J. Clust. Sci. 2017, 28, 119-132. [CrossRef]

161. Mata, R.; Nakkala, J.R.; Sadras, S.R. Polyphenol stabilized colloidal gold nanoparticles from Abutilon indicum leaf extract induce apoptosis in HT-29 colon cancer cells. Colloids Surf. B. Biointerfaces 2016, 143, 499-510. [CrossRef]

162. Muthukumar, T.; Sudhakumari; Sambandam, B.; Aravinthan, A.; Sastry, T.P.; Kim, J.-H. Green synthesis of gold nanoparticles and their enhanced synergistic antitumor activity using HepG2 and MCF7 cells and its antibacterial effects. Process. Biochem. 2016, 51, 384-391. [CrossRef]

163. Arunachalam, K.D.; Arun, L.B.; Annamalai, S.K.; Arunachalam, A.M. Biofunctionalized gold nanoparticles synthesis from Gymnema sylvestre and its preliminary anticancer activity. Int. J. Pharm. Pharm. Sci. 2014, 6, 423-430.

164. Mishra, P.; Ray, S.; Sinha, S.; Das, B.; Khan, M.I.; Behera, S.K.; Yun, S.-I.; Tripathy, S.K.; Mishra, A. Facile bio-synthesis of gold nanoparticles by using extract of Hibiscus sabdariffa and evaluation of its cytotoxicity against U87 glioblastoma cells under hyperglycemic condition. Biochem. Eng. J. 2016, 105, 264-272. [CrossRef]

165. Patil, M.P.; Kim, G.-D. Eco-friendly approach for nanoparticles synthesis and mechanism behind antibacterial activity of silver and anticancer activity of gold nanoparticles. Appl. Microbiol. Biotechnol. 2017, 101, 79-92. [CrossRef] [PubMed]

166. Koperuncholan, $\mathrm{M}$. Bioreduction of chloroauric acid $(\mathrm{HAuCl})$ for the synthesis of gold nanoparticles (GNPs): A special empathies of pharmacological activity. Int. J. Phytopharm. 2015, 5, 72-80. [CrossRef]

167. Tiloke, C.; Phulukdaree, A.; Anand, K.; Gengan, R.M.; Chuturgoon, A.A. Moringa oleifera Gold Nanoparticles Modulate Oncogenes, Tumor Suppressor Genes, and Caspase-9 Splice Variants in A549 Cells. J. Cell. Biochem. 2016, 117, $2302-2314$. [CrossRef] [PubMed]

168. Jeyaraj, M.; Arun, R.; Sathishkumar, G.; MubarakAli, D.; Rajesh, M.; Sivanandhan, G.; Kapildev, G.; Manickavasagam, M.; Thajuddin, N.; Ganapathi, A. An evidence on G2/M arrest, DNA damage and caspase mediated apoptotic effect of biosynthesized gold nanoparticles on human cervical carcinoma cells (HeLa). Mater. Res. Bull. 2014, 52, 15-24. [CrossRef]

169. Rajan, A.; Rajan, A.R.; Philip, D. Elettaria cardamomum seed mediated rapid synthesis of gold nanoparticles and its biological activities. OpenNano 2017, 2, 1-8. [CrossRef]

170. Dhayalan, M.; Denison, M.I.J.; Ayyar, M.; Gandhi, N.N.; Krishnan, K.; Abdulhadi, B. Biogenic synthesis, characterization of gold and silver nanoparticles from Coleus forskohlii and their clinical importance. J. Photochem. Photobiol. B Biol. 2018, 183, $251-257$. [CrossRef] [PubMed]

171. Wang, L.; Xu, J.; Yan, Y.; Liu, H.; Li, F. Synthesis of gold nanoparticles from leaf Panax notoginseng and its anticancer activity in pancreatic cancer PANC-1 cell lines. Artif. Cells Nanomed. Biotechnol. 2019, 47, 1216-1223. [CrossRef]

172. Mmola, M.; Roes-Hill, M.L.; Durrell, K.; Bolton, J.J.; Sibuyi, N.; Meyer, M.E.; Beukes, D.R.; Antunes, E. Enhanced Antimicrobial and Anticancer Activity of Silver and Gold Nanoparticles Synthesised Using Sargassum incisifolium Aqueous Extracts. Molecules 2016, 21, 1633. [CrossRef] 
173. Balasubramani, G.; Ramkumar, R.; Krishnaveni, N.; Pazhanimuthu, A.; Natarajan, T.; Sowmiya, R.; Perumal, P. Structural characterization, antioxidant and anticancer properties of gold nanoparticles synthesized from leaf extract(decoction)of Antigonon leptopus Hook. \& Arn. J. Trace Elem. Med. Biol. Organ Soc. Miner. Trace Elem. 2015, 30, 83-89. [CrossRef]

174. Devi, G.K.; Sathishkumar, K. Synthesis of gold and silver nanoparticles using Mukia maderaspatna plant extract and its anticancer activity. IET Nanobiotechnol. 2017, 11, 143-151. [CrossRef]

175. Santos, N.M.; Gomes, A.S.; Cavalcante, D.G.S.M.; Santos, L.F.; Teixeira, S.R.; Cabrera, F.C.; Job, A.E. Green synthesis of colloidal gold nanoparticles using latex from Hevea brasiliensis and evaluation of their in vitro cytotoxicity and genotoxicity. IET Nanobiotechnol. 2019, 13, 307-315. [CrossRef]

176. Patil, M.P.; Bayaraa, E.; Subedi, P.; Piad, L.L.A.; Tarte, N.H.; Kim, G.-D. Biogenic synthesis, characterization of gold nanoparticles using Lonicera japonica and their anticancer activity on HeLa cells. J. Drug Deliv. Sci. Technol. 2019, 51, 83-90. [CrossRef]

177. Sunderam, V.; Thiyagarajan, D.; Lawrence, A.V.; Mohammed, S.S.S.; Selvaraj, A. In-vitro antimicrobial and anticancer properties of green synthesized gold nanoparticles using Anacardium occidentale leaves extract. Saudi J. Biol. Sci. 2019, 26, 455-459. [CrossRef]

178. Patil, M.P.; Jin, X.; Simeon, N.C.; Palma, J.; Kim, D.; Ngabire, D.; Kim, N.-H.; Tarte, N.H.; Kim, G.-D. Anticancer activity of Sasa borealis leaf extract-mediated gold nanoparticles. Artif. Cells Nanomed. Biotechnol. 2018, 46, 82-88. [CrossRef]

179. Qian, L.; Su, W.; Wang, Y.; Dang, M.; Zhang, W.; Wang, C. Synthesis and characterization of gold nanoparticles from aqueous leaf extract of Alternanthera sessilis and its anticancer activity on cervical cancer cells (HeLa). Artif. Cells Nanomed. Biotechnol. 2019, 47, 1173-1180. [CrossRef]

180. Vijayan, R.; Joseph, S.; Mathew, B. Anticancer, antimicrobial, antioxidant, and catalytic activities of green-synthesized silver and gold nanoparticles using Bauhinia purpurea leaf extract. Bioprocess. Biosyst. Eng. 2019, 42, 305-319. [CrossRef]

181. Adewale, O.B.; Anadozie, S.O.; Potts-Johnson, S.S.; Onwuelu, J.O.; Obafemi, T.O.; Osukoya, O.A.; Fadaka, A.O.; Davids, H.; Roux, $\mathrm{S}$. Investigation of bioactive compounds in Crassocephalum rubens leaf and in vitro anticancer activity of its biosynthesized gold nanoparticles. Biotechnol. Rep. 2020, 28, e00560. [CrossRef]

182. Khandanlou, R.; Murthy, V.; Saranath, D.; Damani, H. Synthesis and characterization of gold-conjugated Backhousia citriodora nanoparticles and their anticancer activity against MCF-7 breast and HepG2 liver cancer cell lines. J. Mater. Sci. 2018, 53, 3106-3118. [CrossRef]

183. El-Borady, O.M.; Ayat, M.S.; Shabrawy, M.A.; Millet, P. Green synthesis of gold nanoparticles using Parsley leaves extract and their applications as an alternative catalytic, antioxidant, anticancer, and antibacterial agents. Adv. Powder Technol. 2020, 31, 4390-4400. [CrossRef]

184. Vijayan, R.; Joseph, S.; Mathew, B. Indigofera tinctoria leaf extract mediated green synthesis of silver and gold nanoparticles and assessment of their anticancer, antimicrobial, antioxidant and catalytic properties. Artif. Cells Nanomed. Biotechnol. 2018, 46, 861-871. [CrossRef]

185. Lim, Z.-Z.J.; Li, J.-E.J.; Ng, C.-T.; Yung, L.-Y.L.; Bay, B.-H. Gold nanoparticles in cancer therapy. Acta Pharmacol. Sin. 2011, 32, 983-990. [CrossRef]

186. Jain, N.; Jain, P.; Rajput, D.; Patil, U.K. Green synthesized plant-based silver nanoparticles: Therapeutic prospective for anticancer and antiviral activity. Micro Nano Syst. Lett. 2021, 9, 5. [CrossRef]

187. Singh, G.; Babele, P.K.; Shahi, S.K.; Sinha, R.P.; Tyagi, M.B.; Kumar, A. Green synthesis of silver nanoparticles using cell extracts of Anabaena doliolum and screening of its antibacterial and antitumor activity. J. Microbiol. Biotechnol. 2014, 24, 1354-1367. [CrossRef]

188. Pan, Y.; Neuss, S.; Leifert, A.; Fischler, M.; Wen, F.; Simon, U.; Schmid, G.; Brandau, W.; Jahnen-Dechent, W. Size-dependent cytotoxicity of gold nanoparticles. Small 2007, 3, 1941-1949. [CrossRef]

189. Cui, W.; Li, J.; Zhang, Y.; Rong, H.; Lu, W.; Jiang, L. Effects of aggregation and the surface properties of gold nanoparticles on cytotoxicity and cell growth. Nanomedicine 2012, 8, 46-53. [CrossRef]

190. Gong, N.; Chen, S.; Jin, S.; Zhang, J.; Wang, P.C.; Liang, X.-J. Effects of the physicochemical properties of gold nanostructures on cellular internalization. Regen. Biomater. 2015, 2, 273-280. [CrossRef]

191. Albanese, A.; Tang, P.S.; Chan, W.C.W. The effect of nanoparticle size, shape, and surface chemistry on biological systems. Annu. Rev. Biomed. Eng. 2012, 14, 1-16. [CrossRef]

192. Xia, T.; Kovochich, M.; Brant, J.; Hotze, M.; Sempf, J.; Oberley, T.; Sioutas, C.; Yeh, J.I.; Wiesner, M.R.; Nel, A.E. Comparison of the abilities of ambient and manufactured nanoparticles to induce cellular toxicity according to an oxidative stress paradigm. Nano Lett. 2006, 6, 1794-1807. [CrossRef]

193. Sun, H.; Liu, Y.; Bai, X.; Zhou, X.; Zhou, H.; Liu, S.; Yan, B. Induction of oxidative stress and sensitization of cancer cells to paclitaxel by gold nanoparticles with different charge densities and hydrophobicities. J. Mater. Chem. B 2018, 6, 1633-1639. [CrossRef]

194. Parida, U.; Biswal, S.; Bindhani, B.K. Green Synthesis and Characterization of Gold Nanoparticles: Study of Its Biological Mechanism in Human SUDHL-4 Cell Line. Adv. Biol. Chem. 2014, 4, 360-375. [CrossRef]

195. Redza-Dutordoir, M.; Averill-Bates, D.A. Activation of apoptosis signalling pathways by reactive oxygen species. Biochim. Biophys. Acta-Mol. Cell Res. 2016, 1863, 2977-2992. [CrossRef]

196. Elmore, S. Apoptosis: A review of programmed cell death. Toxicol. Pathol. 2007, 35, 495-516. [CrossRef] 
197. Zorov, D.B.; Juhaszova, M.; Sollott, S.J. Mitochondrial reactive oxygen species (ROS) and ROS-induced ROS release. Physiol. Rev. 2014, 94, 909-950. [CrossRef]

198. Arnoult, D.; Gaume, B.; Karbowski, M.; Sharpe, J.C.; Cecconi, F.; Youle, R.J. Mitochondrial release of AIF and EndoG requires caspase activation downstream of Bax/Bak-mediated permeabilization. EMBO J. 2003, 22, 4385-4399. [CrossRef]

199. Wang, C.; Youle, R.J. The role of mitochondria in apoptosis*. Annu. Rev. Genet. 2009, 43, 95-118. [CrossRef]

200. Shen, H.-M.; Liu, Z. JNK signaling pathway is a key modulator in cell death mediated by reactive oxygen and nitrogen species. Free Radic. Biol. Med. 2006, 40, 928-939. [CrossRef]

201. Han, J.; Lv, W.; Sheng, H.; Wang, Y.; Cao, L.; Huang, S.; Zhu, L.; Hu, J. Ecliptasaponin A induces apoptosis through the activation of ASK1/JNK pathway and autophagy in human lung cancer cells. Ann. Transl. Med. 2019, 7, 539. [CrossRef]

202. Cory, S.; Adams, J.M. The Bcl2 family: Regulators of the cellular life-or-death switch. Nat. Rev. Cancer 2002, 2, 647-656. [CrossRef]

203. Seervi, M.; Xue, D. Mitochondrial Cell Death Pathways in Caenorhabiditis elegans. Curr. Top. Dev. Biol. 2015, 114, 43-65. [CrossRef]

204. Ahmad, N.; Sharma, A.K.; Sharma, S.; Khan, I.; Sharma, D.K.; Shamsi, A.; Santhosh Kumar, T.R.; Seervi, M. Biosynthesized composites of Au-Ag nanoparticles using Trapa peel extract induced ROS-mediated p53 independent apoptosis in cancer cells. Drug Chem. Toxicol. 2019, 42, 43-53. [CrossRef]

205. Cohen, G.M. Caspases: The executioners of apoptosis. Biochem. J. 1997, 326, 1-16. [CrossRef]

206. Noël, C.; Simard, J.-C.; Girard, D. Gold nanoparticles induce apoptosis, endoplasmic reticulum stress events and cleavage of cytoskeletal proteins in human neutrophils. Toxicol. In Vitro 2016, 31, 12-22. [CrossRef]

207. Abdel-Ghany, S.; Mahfouz, M.; Ashraf, N.; Sabit, H.; Cevik, E.; El-Zawahri, M. Gold nanoparticles induce G2/M cell cycle arrest and enhance the expression of E-cadherin in breast cancer cells. Inorg. Nano-Metal. Chem. 2020, 50, 926-932. [CrossRef]

208. Rónavári, A.; Igaz, N.; Adamecz, D.I.; Szerencsés, B.; Molnar, C.; Kónya, Z.; Pfeiffer, I.; Kiricsi, M. Green Silver and Gold Nanoparticles: Biological Synthesis Approaches and Potentials for Biomedical Applications. Molecules 2021, 26, 844. [CrossRef]

209. Sharma, M.; Salisbury, R.L.; Maurer, E.I.; Hussain, S.M.; Sulentic, C.E.W. Gold nanoparticles induce transcriptional activity of NF-kB in a B-lymphocyte cell line. Nanoscale 2013, 5, 3747-3756. [CrossRef]

210. Soni, N.; Soni, N.; Pandey, H. Augmented delivery of gemcitabine in lung cancer cells exploring mannose anchored solid lipid nanoparticles. J. Colloid Interface Sci. 2016, 481, 107-116. [CrossRef]

211. Morsi, N.; Ibrahim, M.; Refai, H. Nanoemulsion-based electrolyte triggered in situ gel for ocular delivery of acetazolamide. Eur. J. Pharm. Sci. 2017, 104, 302-314. [CrossRef]

212. Huang, Y.; Tao, Q.; Hou, D.; Hu, S.; Tian, S.; Chen, Y.; Yang, L.; Wang, Y. a novel ion-exchange carrier based upon liposomeencapsulated montmorillonite for ophthalmic delivery of betaxolol hydrochloride. Int. J. Nanomed. 2017, 12-1731. [CrossRef]

213. Maheshwari, R.; Thakur, S. Chitosan encrusted nonionic surfactant based vesicular formulation for topical administration of ofloxacin. Sci. Adv. Mater. 2015, 7, 1163-1176. [CrossRef]

214. Huang, J.; Peng, T.; Li, Y.; Zhan, Z.; Zeng, Y.; Huang, Y.; Pan, X.; Wu, C.-Y.; Wu, C. Ocular Cubosome Drug Delivery System for Timolol Maleate: Preparation, Characterization, Cytotoxicity, Ex Vivo, and In Vivo Evaluation. AAPS PharmSciTech 2017, 18, 2919-2926. [CrossRef]

215. Al-mahallawi, A.M.; Khowessah, O.M.; Shoukri, R.A. Enhanced non invasive trans-tympanic delivery of ciprofloxacin through encapsulation into nano-spanlastic vesicles: Fabrication, in-vitro characterization, and comparative ex-vivo permeation studies. Int. J. Pharm. 2017, 522, 157-164. [CrossRef]

216. Mandal, A.; Bisht, R.; Rupenthal, I.; Release, A.M.-J. Polymeric micelles for ocular drug delivery: From structural frameworks to recent preclinical studies. J. Control. Release 2017, 248, 96-116. [CrossRef]

217. Almeida, H.; Lobão, P.; Frigerio, C. Preparation, characterization and biocompatibility studies of thermoresponsive eyedrops based on the combination of nanostructured lipid carriers (NLC) and the polymer Pluronic F-127 for controlled delivery of ibuprofen. Pharm. Dev. Technol. 2017, 22, 336-349. [CrossRef]

218. Al-Radadi, N.S. Facile one-step green synthesis of gold nanoparticles (AuNp) using licorice root extract: Antimicrobial and anticancer study against HepG2 cell line. Arab. J. Chem. 2021, 14, 102956. [CrossRef]

219. Gour, A.; Jain, N.K. Advances in green synthesis of nanoparticles. Taylor Fr. 2019, 47, 844-851. [CrossRef]

220. Jo, D.H.; Kim, J.H.; Lee, T.G.; Kim, J.H. Size, surface charge, and shape determine therapeutic effects of nanoparticles on brain and retinal diseases. Nanomed. Nanotechnol. Biol. Med. 2015, 11, 1603-1611. [CrossRef]

221. Chen, Y.; Tsai, C.; Huang, P. Methotrexate conjugated to gold nanoparticles inhibits tumor growth in a syngeneic lung tumor model. ACS Publ. 2007, 4, 713-722. [CrossRef]

222. Bhattacharya, R.; Patra, C.R.; Earl, A.; Wang, S.; Katarya, A.; Lu, L.; Kizhakkedathu, J.N.; Yaszemski, M.J.; Greipp, P.R.; Mukhopadhyay, D.; et al. Attaching folic acid on gold nanoparticles using noncovalent interaction via different polyethylene glycol backbones and targeting of cancer cells. Nanomed. Nanotechnol. Biol. Med. 2007, 3, 224-238. [CrossRef]

223. Lu, W.; Singh, A.; Khan, S. Gold nano-popcorn-based targeted diagnosis, nanotherapy treatment, and in situ monitoring of photothermal therapy response of prostate cancer cells using surface. ACS Publ. 2010, 132, 18103-18114. [CrossRef]

224. Mieszawska, A.J.; Mulder, W.J.M.; Fayad, Z.A.; Cormode, D.P. Multifunctional Gold Nanoparticles for Diagnosis and Therapy of Disease. Mol. Pharm. 2013, 10, 831-847. [CrossRef]

225. Agasti, S.S.; Chompoosor, A.; You, C.-C.; Ghosh, P.; Kim, C.K.; Rotello, V.M. Photoregulated release of caged anticancer drugs from gold nanoparticles. J. Am. Chem. Soc. 2009, 131, 5728-5729. [CrossRef] 
226. Wang, D.; Xu, Z.; Yu, H.; Chen, X.; Feng, B.; Cui, Z.; Lin, B.; Yin, Q.; Zhang, Z.; Chen, C.; et al. Treatment of metastatic breast cancer by combination of chemotherapy and photothermal ablation using doxorubicin-loaded DNA wrapped gold nanorods. Biomaterials 2014, 35, 8374-8384. [CrossRef]

227. Barar, J.; Omidi, Y. Dysregulated pH in Tumor Microenvironment Checkmates Cancer Therapy. Bioimpacts $2013,3,149-162$. [CrossRef] [PubMed]

228. Asgharzadeh, M.R.; Barar, J.; Pourseif, M.M.; Eskandani, M.; Niya, M.J.; Mashayekhi, M.R.; Omidi, Y. Molecular machineries of $\mathrm{pH}$ dysregulation in tumor microenvironment: Potential targets for cancer therapy. Tabriz Univ. Med. Sci. 2017, 7, 115-133. [CrossRef]

229. Joshi, P.; Chakraborti, S.; Ramirez-Vick, J.E.; Ansari, Z.A.; Shanker, V.; Chakrabarti, P.; Singh, S.P. The anticancer activity of chloroquine-gold nanoparticles against MCF-7 breast cancer cells. Colloids Surf. B. Biointerfaces 2012, 95, 195-200. [CrossRef]

230. Hao, L.; Patel, P.C.; Alhasan, A.H.; Giljohann, D.A.; Mirkin, C.A. Nucleic acid-gold nanoparticle conjugates as mimics of microRNA. Small 2011, 7, 3158-3162. [CrossRef]

231. Gong, F.; Yang, N.; Wang, X.; Zhao, Q.; Chen, Q.; Liu, Z.; Cheng, L. Tumor microenvironment-responsive intelligent nanoplatforms for cancer theranostics. Nano Today 2020, 32, 100851. [CrossRef]

232. Luo, D.; Wang, X.; Burda, C.; Basilion, J.P. Recent Development of Gold Nanoparticles as Contrast Agents for Cancer Diagnosis. Cancers 2021, 13, 1825. [CrossRef]

233. Singh, P.; Pandit, S.; Mokkapati, V.R.S.S.; Garg, A.; Ravikumar, V.; Mijakovic, I. Gold Nanoparticles in Diagnostics and Therapeutics for Human Cancer. Int. J. Mol. Sci. 2018, 19, 1979. [CrossRef]

234. Faheem, S.; Hussaina, B. Gold Nanoparticles in Cancer Diagnosis and Treatment: A Review. Austin J. Biotechnol. Bioeng. 2014, 1, 5.

235. Zhang, Q.; Yang, M.; Zhu, Y.; Mao, C. Metallic Nanoclusters for Cancer Imaging and Therapy. Curr. Med. Chem. 2018, 25, 1379-1396. [CrossRef]

236. Katas, H.; Moden, N.Z.; Lim, C.S.; Celesistinus, T.; Chan, J.Y.; Ganasan, P.; Suleman Ismail Abdalla, S. Biosynthesis and Potential Applications of Silver and Gold Nanoparticles and Their Chitosan-Based Nanocomposites in Nanomedicine. J. Nanotechnol. 2018, 2018, 4290705. [CrossRef]

237. Chen, X.-J.; Zhang, X.-Q.; Liu, Q.; Zhang, J.; Zhou, G. Nanotechnology: A promising method for oral cancer detection and diagnosis. J. Nanobiotechnol. 2018, 16, 52. [CrossRef]

238. Zhou, W.; Gao, X.; Liu, D.; Chen, X. Gold Nanoparticles for In Vitro Diagnostics. Chem. Rev. 2015, 115, 10575-10636. [CrossRef]

239. Huang, Q.; Wang, Y.; Chen, X.; Wang, Y.; Li, Z.; Du, S.; Wang, L.; Chen, S. Nanotechnology-Based Strategies for Early Cancer Diagnosis Using Circulating Tumor Cells as a Liquid Biopsy. Nanotheranostics 2018, 2, 21-41. [CrossRef] [PubMed]

240. Luo, D.; Johnson, A.; Wang, X.; Li, H.; Erokwu, B.O.; Springer, S.; Lou, J.; Ramamurthy, G.; Flask, C.A.; Burda, C.; et al. Targeted Radiosensitizers for MR-Guided Radiation Therapy of Prostate Cancer. Nano Lett. 2020, 20, 7159-7167. [CrossRef]

241. Luo, D.; Wang, X.; Zeng, S.; Ramamurthy, G.; Burda, C.; Basilion, J.P. Prostate-specific membrane antigen targeted gold nanoparticles for prostate cancer radiotherapy: Does size matter for targeted particles? Chem. Sci. 2019, 10, 8119-8128. [CrossRef]

242. Zhou, C.; Hao, G.; Thomas, P.; Liu, J.; Yu, M.; Sun, S.; Öz, O.K.; Sun, X.; Zheng, J. Near-Infrared Emitting Radioactive Gold Nanoparticles with Molecular Pharmacokinetics. Angew. Chem. Int. Ed. 2012, 51, 10118-10122. [CrossRef]

243. Zhao, Y.; Sultan, D.; Detering, L.; Luehmann, H.; Liu, Y. Facile synthesis, pharmacokinetic and systemic clearance evaluation, and positron emission tomography cancer imaging of ${ }^{64} \mathrm{Cu}$-Au alloy nanoclusters. Nanoscale 2014, 6, 13501-13509. [CrossRef]

244. Zhao, Y.; Detering, L.; Sultan, D.; Cooper, M.L.; You, M.; Cho, S.; Meier, S.L.; Luehmann, H.; Sun, G.; Rettig, M.; et al. Gold Nanoclusters Doped with (64)Cu for CXCR4 Positron Emission Tomography Imaging of Breast Cancer and Metastasis. ACS Nano 2016, 10, 5959-5970. [CrossRef]

245. Yang, J.; Wang, T.; Zhao, L.; Rajasekhar, V.K.; Joshi, S.; Andreou, C.; Pal, S.; Hsu, H.; Zhang, H.; Cohen, I.J.; et al. Gold/alphalactalbumin nanoprobes for the imaging and treatment of breast cancer. Nat. Biomed. Eng. 2020, 4, 686-703. [CrossRef]

246. Han, S.; Bouchard, R.; Sokolov, K. V Molecular photoacoustic imaging with ultra-small gold nanoparticles. Biomed. Opt. Express 2019, 10, 3472-3483. [CrossRef]

247. Morel, A.-L.; Giraud, S.; Bialecki, A.; Moustaoui, H.; de La Chapelle, M.L.; Spadavecchia, J. Green extraction of endemic plants to synthesize gold nanoparticles for theranostic applications. Front. Lab. Med. 2017, 1, 158-171. [CrossRef]

248. Kim, T.; Zhang, Q.; Li, J.; Zhang, L.; Jokerst, J. V A Gold/Silver Hybrid Nanoparticle for Treatment and Photoacoustic Imaging of Bacterial Infection. ACS Nano 2018, 12, 5615-5625. [CrossRef]

249. Tian, Y.; Zhang, Y.; Teng, Z.; Tian, W.; Luo, S.; Kong, X.; Su, X.; Tang, Y.; Wang, S.; Lu, G. pH-Dependent Transmembrane Activity of Peptide-Functionalized Gold Nanostars for Computed Tomography/Photoacoustic Imaging and Photothermal Therapy. ACS Appl. Mater. Interfaces 2017, 9, 2114-2122. [CrossRef]

250. Li, C.; Zhang, Y.; Li, Z.; Mei, E.; Lin, J.; Li, F.; Chen, C.; Qing, X.; Hou, L.; Xiong, L.; et al. Light-Responsive Biodegradable Nanorattles for Cancer Theranostics. Adv. Mater. 2018, 30, 1706150. [CrossRef]

251. Zhang, M.; Chen, X.; Zhang, L.; Li, L.; Su, Z.-M.; Wang, C. Spadix-Bract Structured Nanobowls for Bimodal Imaging-Guided Multidrug Chemo-Photothermal Synergistic Therapy. Chem. Mater. 2018, 30, 3722-3733. [CrossRef]

252. Xue, N.; Zhou, C.; Chu, Z.; Chen, L.; Jia, N. Barley leaves mediated biosynthesis of Au nanomaterials as a potential contrast agent for computed tomography imaging. Sci. China Technol. Sci. 2021, 64, 433-440. [CrossRef]

253. Fan, M.; Han, Y.; Gao, S.; Yan, H.; Cao, L.; Li, Z.; Liang, X.-J.; Zhang, J. Ultrasmall gold nanoparticles in cancer diagnosis and therapy. Theranostics 2020, 10, 4944-4957. [CrossRef] 
254. Kwon, K.C.; Jo, E.; Kwon, Y.-W.; Lee, B.; Ryu, J.H.; Lee, E.J.; Kim, K.; Lee, J. Superparamagnetic Gold Nanoparticles Synthesized on Protein Particle Scaffolds for Cancer Theragnosis. Adv. Mater. 2017, 29, 1701146. [CrossRef]

255. Mahmoudi, M.; Hofmann, H.; Rothen-Rutishauser, B.; Petri-Fink, A. Assessing the in vitro and in vivo toxicity of superparamagnetic iron oxide nanoparticles. Chem. Rev. 2012, 112, 2323-2338. [CrossRef]

256. Narayanan, S.; Sathy, B.N.; Mony, U.; Koyakutty, M.; Nair, S.V.; Menon, D. Biocompatible Magnetite/Gold Nanohybrid Contrast Agents via Green Chemistry for MRI and CT Bioimaging. ACS Appl. Mater. Interfaces 2012, 4, 251-260. [CrossRef]

257. Sabale, S.; Kandesar, P.; Jadhav, V.; Komorek, R.; Motkuri, R.K.; Yu, X.-Y. Recent developments in the synthesis, properties, and biomedical applications of core/shell superparamagnetic iron oxide nanoparticles with gold. Biomater. Sci. 2017, 5, $2212-2225$. [CrossRef]

258. Hainfeld, J.F.; Dilmanian, F.A.; Slatkin, D.N.; Smilowitz, H.M. Radiotherapy enhancement with gold nanoparticles. J. Pharm. Pharmacol. 2008, 60, 977-985. [CrossRef]

259. He, H.; Xie, C.; Ren, J. Nonbleaching Fluorescence of Gold Nanoparticles and Its Applications in Cancer Cell Imaging. Anal. Chem. 2008, 80, 5951-5957. [CrossRef]

260. Mukherjee, S.; Vinothkumar, B.; Prashanthi, S.; Bangal, P.R.; Sreedhar, B.; Patra, C.R. Potential therapeutic and diagnostic applications of one-step in situ biosynthesized gold nanoconjugates (2-in-1 system) in cancer treatment. RSC Adv. 2013, 3, 2318-2329. [CrossRef]

261. Li, W.; Chen, X. Gold nanoparticles for photoacoustic imaging. Nanomedicine 2015, 10, 299-320. [CrossRef]

262. Kang, M.S.; Lee, S.Y.; Kim, K.S.; Han, D.-W. State of the Art Biocompatible Gold Nanoparticles for Cancer Theragnosis. Pharmaceutics 2020, 12, 701. [CrossRef] [PubMed]

263. García-Álvarez, R.; Chen, L.; Nedilko, A.; Sánchez-Iglesias, A.; Rix, A.; Lederle, W.; Pathak, V.; Lammers, T.; von Plessen, G.; Kostarelos, K.; et al. Optimizing the Geometry of Photoacoustically Active Gold Nanoparticles for Biomedical Imaging. ACS Photonics 2020, 7, 646-652. [CrossRef]

264. Chanda, N.; Shukla, R.; Zambre, A.; Mekapothula, S.; Kulkarni, R.R.; Katti, K.; Bhattacharyya, K.; Fent, G.M.; Casteel, S.W.; Boote, E.J.; et al. An effective strategy for the synthesis of biocompatible gold nanoparticles using cinnamon phytochemicals for phantom CT imaging and photoacoustic detection of cancerous cells. Pharm. Res. 2011, 28, 279-291. [CrossRef] [PubMed]

265. Gleich, B.; Weizenecker, J. Tomographic imaging using the nonlinear response of magnetic particles. Nature 2005, 435, 1214-1217. [CrossRef]

266. Billings, C.; Langley, M.; Warrington, G.; Mashali, F.; Johnson, J.A. Magnetic Particle Imaging: Current and Future Applications, Magnetic Nanoparticle Synthesis Methods and Safety Measures. Int. J. Mol. Sci. 2021, 22, 7651. [CrossRef] [PubMed]

267. Wu, K.; Su, D.; Saha, R.; Liu, J.; Chugh, V.K.; Wang, J.-P. Magnetic Particle Spectroscopy: A Short Review of Applications Using Magnetic Nanoparticles. ACS Appl. Nano Mater. 2020, 3, 4972-4989. [CrossRef]

268. Tomitaka, A.; Arami, H.; Huang, Z.; Raymond, A.; Rodriguez, E.; Cai, Y.; Febo, M.; Takemura, Y.; Nair, M. Hybrid magnetoplasmonic liposomes for multimodal image-guided and brain-targeted HIV treatment. Nanoscale 2017, 10, 184-194. [CrossRef]

269. Tomitaka, A.; Arami, H.; Ahmadivand, A.; Pala, N.; McGoron, A.J.; Takemura, Y.; Febo, M.; Nair, M. Magneto-plasmonic nanostars for image-guided and NIR-triggered drug delivery. Sci. Rep. 2020, 10, 10115. [CrossRef]

270. Jiao, Q.; Li, L.; Mu, Q.; Zhang, Q. Immunomodulation of Nanoparticles in Nanomedicine Applications. Biomed. Res. Int. 2014, 2014, 426028. [CrossRef]

271. Michelini, S.; Barbero, F.; Prinelli, A.; Steiner, P.; Weiss, R.; Verwanger, T.; Andosch, A.; Lütz-Meindl, U.; Puntes, V.F.; Drobne, D.; et al. Gold nanoparticles (AuNPs) impair LPS-driven immune responses by promoting a tolerogenic-like dendritic cell phenotype with altered endosomal structures. Nanoscale 2021, 13, 7648-7666. [CrossRef]

272. Ahmad, S.; Zamry, A.A.; Tan, H.-T.T.; Wong, K.K.; Lim, J.; Mohamud, R. Targeting dendritic cells through gold nanoparticles: A review on the cellular uptake and subsequent immunological properties. Mol. Immunol. 2017, 91, 123-133. [CrossRef]

273. Pahwa, R.; Goyal, A.; Bansal, P.; Jialal, I. Chronic Inflammation; StatPearls: Treasure Island, FL, USA, 2021.

274. Khan, H.A.; Abdelhalim, M.A.K.; Alhomida, A.S.; Al Ayed, M.S. Transient increase in IL-1 $\beta$, IL-6 and TNF- $\alpha$ gene expression in rat liver exposed to gold nanoparticles. Genet. Mol. Res. 2013, 12, 5851-5857. [CrossRef]

275. Abdal Dayem, A.; Hossain, M.K.; Lee, S.B.; Kim, K.; Saha, S.K.; Yang, G.-M.; Choi, H.Y.; Cho, S.-G. The Role of Reactive Oxygen Species (ROS) in the Biological Activities of Metallic Nanoparticles. Int. J. Mol. Sci. 2017, 18, 120. [CrossRef]

276. Bercovici, N.; Guérin, M.V.; Trautmann, A.; Donnadieu, E. The Remarkable Plasticity of Macrophages: A Chance to Fight Cancer. Front. Immunol. 2019, 10, 1563. [CrossRef] [PubMed]

277. Almatroodi, S.A.; McDonald, C.F.; Darby, I.A.; Pouniotis, D.S. Characterization of M1/M2 Tumour-Associated Macrophages (TAMs) and Th1/Th2 Cytokine Profiles in Patients with NSCLC. Cancer Microenviron. Off. J. Int. Cancer Microenviron. Soc. 2016, 9 , 1-11. [CrossRef] [PubMed]

278. Yuri, P.; Shigemura, K.; Kitagawa, K.; Hadibrata, E.; Risan, M.; Zulfiqqar, A.; Soeroharjo, I.; Hendri, A.Z.; Danarto, R.; Ishii, A.; et al. Increased tumor-associated macrophages in the prostate cancer microenvironment predicted patients' survival and responses to androgen deprivation therapies in Indonesian patients cohort. Prostate Int. 2020, 8, 62-69. [CrossRef] [PubMed]

279. Khan, Y.; Roy, M. Synthesis, Limitation and Application of Gold Nanoparticles in Treatment of Cancerous Cell. Int. J. Sci. Res. Multidiscip. Stud. 2019, 5, 8-14. [CrossRef] 
280. Egbuna, C.; Parmar, V.K.; Jeevanandam, J.; Ezzat, S.M.; Patrick-Iwuanyanwu, K.C.; Adetunji, C.O.; Khan, J.; Onyeike, E.N.; Uche, C.Z.; Akram, M.; et al. Toxicity of Nanoparticles in Biomedical Application: Nanotoxicology. J. Toxicol. 2021, 2021, 9954443. [CrossRef]

281. Arvizo, R.; Bhattacharya, R.; Mukherjee, P. Gold nanoparticles: Opportunities and challenges in nanomedicine. Expert Opin. Drug Deliv. 2010, 7, 753-763. [CrossRef]

282. Murali, K.; Neelakandan, M.; Thomas, S. Biomedical Applications of Gold Nanoparticles. JSM Nanotechnol. Nanomed. 2018, 6, 1064.

283. Bonjar, L.S. "Nanogold detoxifying machine" to remove idle nanogold particles from blood stream of cancer patients treated with antibody-nanogold therapeutics. Med. Hypotheses 2013, 80, 601-605. [CrossRef] [PubMed] 